INSTITUTE OF CHEMISTRY OF SÃO CARLOS POST GRADUATION PROGRAM IN CHEMISTRY

Medicinal Chemistry Group - NEQUIMED/IQSC/USP

\title{
STRUCTURE-ACTIVITY RELATIONSHIPS OF CYSTEINE PROTEASE INHIBITORS
}

Fernanda dos Reis Rocho

Advisor: Prof. Dr. Carlos A. Montanari

SÃO CARLOS 


\title{
STRUCTURE-ACTIVITY RELATIONSHIPS OF CYSTEINE PROTEASE INHIBITORS
}

\author{
Masters dissertation presented to the post- \\ graduation program in chemistry of the São \\ Carlos Institute of Chemistry, as required for \\ the achievement of the Title of Master with an \\ emphasis on organic and biological chemistry.
}

Concentration Area: Organic and Biological Chemistry

Advisor: Prof. Dr. Carlos A. Montanari

SÃO CARLOS 


\section{Acknowledgments}

Firstly, I want to thank my family who always supported me and encouraged me to follow my dreams and ambitions. I hope I am making you all proud.

I would like to express my gratitude for my advisor, Prof. Dr. Carlos Alberto Montanari, for the incredible opportunity and experience to work in his laboratory research. For all the knowledge that he and Prof. Dr. Andrei Leitão taught me for these two years of work. I'm very thankful to have worked and learned with you both.

A special thanks to MS Fabiana Rosini, our laboratory technique, who helped me and provided me the protein Cruzain, which she is responsible to express.

I thank MS Lorenzo Cianni, for the friendship and all the help that he gave it to me. Thank you for the patience.

My friends MS Pedro Henrique Jatai Batista, MS Johnatan Mucelini, MS Priscila Felício, MS Lorenzo Cianni and MS Thiago Kelvin that made this journey incredibly easy. Thank you for all the coffees, laughter and advice. And most importantly, thank you for putting up with all my drama and complaints. I love you all.

To my engineer friend MS Neder Blanco, that even far, advised me and helped a lot.

My gratitude for my coworkers of the NEQUIMED/IQSC/USP group, especially Dr. Anwar Shamim. MS Lorenzo Cianni and Dr. Daniela De Vitta, which were responsible for the synthesis of the compounds I have worked with. I also thank the ex-member of the NEQUIMED group Dr. Jean Ribeiro which expressed the protein $\mathrm{LmCPB}$.

Lastly, my gratitude to CNPq for granting me a scholarship, without which I would not have been able to do this work. I also thank IQSC and Fapesp, the former for the great infrastructure I could work on and the latter for funding the thematic project of the NEQUIMED/IQSC/USP group to which I am included. 


\section{RESUMO}

Enzimas são responsáveis por regular grande parte dos processos biossintéticos de organismos vivos. Devido a isso, a identificação de compostos bioativos que atuam em enzimas é fundamental na área de química medicinal. As cisteíno proteases (CPs) apresentam diversas funções essenciais em organismos vivos, logo, membros desta classe de enzimas são considerados alvos promissores para intervenções terapêuticas. Cinco CPs que estão envolvidas em um grande número de doenças humanas foram estudadas neste trabalho, tais como as catepsinas L, S e K, alvos para o câncer e osteoporose, cruzaína e a cisteíno protease da classe B ( $L m \mathrm{CPB})$, alvos para doenças parasitárias como doença de Chagas e leishmanioses, respectivamente. Neste trabalho foi realizada a caracterização cinética de uma série de dipeptidil nitrilas que atuam como inibidores de CPs por meio de ligação covalente reversível. Modificações estruturais foram implementadas nas posições P1, P2, e P3 para avaliar a interação com os correspondentes subsítios S1, S2 e S3 das CPs. Através da análise de pares moleculares (MMP) e relação estrutura atividade (SAR), estimamos como o efeito de não aditividade para diferentes grupos nas posições P1 e P2 pode influenciar no modo geral de interação dos inibidores. Demonstramos que, apesar do grande conhecimento sobre o subsítio $\mathrm{S} 2$, os subsítios S1 e S3 também podem aumentar a afinidade e seletividade para as CPs desejadas. O desenovelamento térmico da cruzaína foi avaliado neste trabalho através da técnica de calorimetria diferencial de varredura (DSC), na qual um desenovelamento irreversível foi obtido. Juntamente, reportamos que alguns dos ligantes utilizados na análise foram capazes de estabilizar a estrutura da cruzaína em mais de $13{ }^{\circ} \mathrm{C}$. Além disso, foi observada uma correlação linear entre a afinidade $\left(\mathrm{p} K_{\mathrm{i}}\right)$ dos ligantes e os valores de $\Delta \mathrm{Tm}$ obtidos para a mesma série de inibidores.

Palavras-chave: Dipeptidil nitrilas, cisteíno proteases, relação estrutura atividade 


\begin{abstract}
Enzymes regulate almost every biosynthetic process of living organisms and the identification of bioactive compounds that act on enzymes is fundamental in the medicinal chemistry field. Cysteine proteases (CPs) have several essential functions in the organisms, and members of this enzyme class are considered to be potential targets for therapeutic intervention. Five CPs that are involved in a range of human diseases were studied in this work, such as cathepsin L, S and $\mathrm{K}$, targets for cancer and osteoporosis, cruzain and class B cysteine protease ( $\operatorname{LmCPB}$ ), targets for parasitic diseases such as Chagas disease and leishmaniasis, respectively. Kinetic characterization for a series of dipeptidyl nitriles that acts as reversible covalent inhibitors of CPs was performed. Structural modifications at the P1, P2, and P3 positions were implemented to study the role of the corresponding A1, S2 and S3 subsites of the CPs. Through a matched molecular pair (MMP) structure-activity relationship (SAR) analysis, we estimated how the nonadditivity effect for different groups in $\mathrm{P} 1$ and $\mathrm{P} 2$ can influence the general mode of binding. We show that besides the well-known S2 pocket also S1 and S3 can enhance affinity and selectivity for the desired CPs. The thermal unfolding of cruzain was evaluated in this work through differential scanning calorimetry (DSC), in which the irreversibility of cruzain unfolding was determined. Herein, we report that some of the ligands were able to stabilize cruzain structure of more than $13{ }^{\circ} \mathrm{C}$. In addition, a trend was observed for a linear correlation between the affinity of the ligands $\left(\mathrm{p} K_{\mathrm{i}}\right)$ and $\Delta \mathrm{Tm}$.
\end{abstract}

Keywords: Dipeptidyl nitriles, cysteine proteases, structure-activity relationship 


\section{FIGURE LIST}

Figure 1: Structural representation of the cysteine protease Falcipain-2 with the active site (in green) in a cleft between the two domains, with the catalytic triad Cys-His-Asn (PDB ID 3PNR).

Figure 2: Schematic representation of the mechanism of peptide hydrolysis played by cysteine proteases.

Figure 3: Recognition subsites pockets nomenclature used for proteolytic enzymes. The numbering increase in the direction of the $\mathrm{N}$-terminal residue of the enzyme.

Figure 4: (a) Three-dimensional structure representation of Cruzain bound covalently to a vinyl $\alpha$-ketoester (PDB ID 1U9Q). (b) Cruzain binding site showing the S1, S2 and S3 pocket, covalently bound to a dipeptidyl nitrile (NEQUIMED/IQSC/USP PBD ID 4QH6). 16

Figure 5: (a) Covalent irreversible inhibitor K777 structure developed by the University of California and (b) Covalent reversible inhibitor BaCZ007 structure of the Merck pharmaceuticals, both cruzain inhibitors.

Figure 6: The dipeptidyl nitrile Odanacatib structure, a covalent reversible inhibitor of the human cathepsin $\mathrm{K}$.

Figure 7: Crystallographic structure representation of the cathepsins L, K, and S subsites. The PDB ID codes for the enzymes are 2Y2J, 4X6H, and 3OVX, respectively.

Figure 8: Generic mechanism in two-step played by covalent inhibitors, where $\mathrm{E}$ is the target enzyme, $\mathrm{I}$ is the inhibitor, E.I is the reversibly bound enzyme-inhibitor complex, and E-I is the formation of a covalent bond between the target and inhibitor.

Figure 9: (a) Dipeptidyl nitrile scaffold with the nitrile group as a warhead. (b) Neq0570 and the mode of interaction with the binding site of the CP.

Figure 10: Structural representation of a dipeptidyl nitrile as cruzain covalent reversible inhibitor used for SAR studies, with the positions were structural modifications occurred market as blue (P2) and red (P3) in the molecule structure.

Figure 11: MMPA for two dipeptidyl nitrile inhibitors of Cathepsin B, where a change, shown in red, for the compound (1) from the compound (2), in orange, exhibit a difference in the activity of $1.0 \log$ unit.

Figure 12: Structures of the substrates Z-Phe-Arg-AMC (a) and Z-Leu-Arg-AMC (b) with their structural differences highlighted in red at the P2 position. The guanidine group $\left(\mathrm{pK}_{\mathrm{a}}=12.5\right)$ of the arginine, present in both substrates, is protonated under the assay conditions $(\mathrm{pH}=5.5)$. 
Figure 13: Velocity plot as a function of Z-Phe-Arg-AMC concentration for cruzain fit in the Michaelis-Menten equation.

Figure 14: Inhibition curve obtained for the prototypic compound Neq0570 against Cruzain in the presence of the substrate Z-Phe-Arg-AMC.

Figure 15: MMPA of Neq0533.1 with seven compounds with $\Delta \mathrm{pK}_{\mathrm{i}}$ values corresponding to structural modifications targeting five enzymes. Positive modifications are shown in green, negative in red, and when no significant difference was observed in grey. Modifications in P1 are highlighted as orange, $\mathrm{P} 2$ blue and $\mathrm{P} 3$ red.

Figure 16: MMPA with $\Delta \mathrm{pK}_{\mathrm{i}}$ values corresponding to structural modifications in the P1 position targeting five enzymes. Positive modifications are shown in green, negative in red, and when no significant difference was observed in grey. Modifications in P1 are marked as orange.

Figure 17: MMPA with $\Delta \mathrm{pK}_{\mathrm{i}}$ values corresponding to structural modifications in P2 and P3 targeting five enzymes. Positive modifications are shown in green, negative in red, and when no significant difference was observed in grey. Modifications in P2 are marked as blue and P3 as red.

Figure 18: Analysis of different stereochemistry in MMP with $\Delta \mathrm{pK}_{\mathrm{i}}$ values corresponding to structural modifications targeting five enzymes. Positive modifications are shown in green, negative in red. Modifications in P1 are marked as orange and P2 as blue.

Figure 19: Nonadditivity in SAR analysis of four compounds where the $\Delta \mathrm{pK}_{\mathrm{i}}$ values shown are related to hCatK inhibition. The green arrow represents positive changes in affinity and the grey arrow no significant change. Blue circles indicate a structural modification in P2 and brown circle in $\mathrm{P} 3$.

Figure 20: Nonadditivity in SAR analysis of six compounds where the $\Delta \mathrm{pK}_{\mathrm{i}}$ values shown are related to cruzain inhibition. The green arrow represents positive changes in affinity, red arrows a negative change in affinity and grey arrow no change in affinity. Orange circles indicate a structural modification in $\mathrm{P} 1$, blue circles modifications in $\mathrm{P} 2$ and brown circle in $\mathrm{P} 3$. 45 Figure 21: Selectivity analysis obtained for LmCPB over hCatL. The compounds in the blue and orange circles have differences in $\mathrm{pK}_{\mathrm{i}}$ greater or equal to $1.0 \log$ units.

Figure 22: Reversibility assay performed for $\mathrm{Cz}$. The blue line corresponds to the first heating scan, ranging from 0 to $90{ }^{\circ} \mathrm{C}$, the green line corresponds to the cooling scan and the red line to the second heating process. The peak of the unfolding process is depicted with $\mathrm{Tm}=66.4{ }^{\circ} \mathrm{C}$. The scans were done at $3 \mathrm{~atm}$ and with a rate of $2{ }^{\circ} \mathrm{C}$ per minute. 
Figure 23: (a) Raw data before the baseline subtraction where the integration of the area of the peak was performed. (b) Cruzain unfolding peak obtained after the correction of the blank (buffer-buffer), the blue line corresponds to the raw data obtained and the red line is the adjustment of the curve using a Two-State Scaled model. The solution was heated from 0 to 90 ${ }^{\circ} \mathrm{C}$ in acetate buffer $\mathrm{pH}=5.5,3 \mathrm{~atm}$ and a rate of $2{ }^{\circ} \mathrm{C} / \mathrm{min}$. 50

Figure 24: Cruzain unfolding peak when incubated with Neq0569.2 obtained after the correction of the blank (buffer-buffer), the blue line corresponds to the raw data obtained and the red line is the adjustment of the curve using a Two-State Scaled model. The solution was heated from 0 to $90{ }^{\circ} \mathrm{C}$ in acetate buffer $\mathrm{pH}=5.5,3 \mathrm{~atm}$ and a rate of $2{ }^{\circ} \mathrm{C} / \mathrm{min}$. 52 Figure 25: Scatter plot correlating affinity $\left(\mathrm{pK}_{\mathrm{i}}\right)$ and thermal stability $(\Delta \mathrm{Tm})$ of $\mathrm{Cz}$ with fourteen inhibitors. 


\section{TABLE LIST}

Table 1: $K_{M}$ and $V_{\max }$ results for the five CPs obtained through the Michaelis-Menten equation. The experimental $\mathrm{K}_{\mathrm{M}}$ results showed at BRENDA website for $\mathrm{Cz}$ is 1 to $3 \mu \mathrm{Mol} \mathrm{L}^{-1}$; $\mathrm{LmCPB}$ 5 to $17 \mu \mathrm{Mol} \mathrm{L}{ }^{-1}$; hCatL $=0.7$ to $6 \mu \mathrm{Mol} \mathrm{L}{ }^{-1}$; hCatS $=14$ to $42 \mu \mathrm{Mol} \mathrm{L}{ }^{-1}$; hCatK is 1.5 to 4.6 $\mu \mathrm{Mol} \mathrm{L}-1$ 31

Table 2: Inhibitors chosen for the SAR and bio calorimetric studies with the $\mathrm{p} K_{\mathrm{i}}$ values for the five CPs, as well as their molecular structures. Protozoa CPs are black colored and mammalian blue-colored

Table 3: $\Delta \mathrm{pK}_{\mathrm{i}}$ for the four CPs from the SAR analysis of Figure 19, the notation $[\mathrm{X} \rightarrow \mathrm{Y}]$ indicates a structural modification. Diagonal transformation is highlighted in orange 43 Table 4: $\Delta \mathrm{pK}_{\mathrm{i}}$ for the four CPs from the SAR analysis of Figure 20 , the notation $[\mathrm{X} \rightarrow \mathrm{Y}]$ indicates a structural modification. Diagonal transformations are highlighted in orange........45 Table 5: Physical-chemical properties of the compounds presented in Figure 20. 46

Table 6: Experimental results of $\mathrm{Cz}$ thermal denaturation. All values are an average of four independent experiments

Table 7: Experimental results obtained for fourteen compounds when incubated with $\mathrm{Cz}$ and analyzed by DSC. The $\Delta \mathrm{Tm}$ was obtained by subtracting the Tm of the incubated protein by the Tm of the native protein. The conditions for the assays were the same used for native cruzain assays with the only difference being the presence of the ligands. The mean values of the two measurements are presented. 


\section{ABREVIATION LIST}

CPs - Cysteine Protease

$\mathrm{Cz}-$ Cruzain

LmCPB - Class B Cysteine Protease from Leishmania

$h$ CatL - Human Cathepsin L

$h$ CatS - Human Cathepsin S

$h$ CatK - Human Cathepsin K

CI - Covalent Inhibitors

$K_{\mathrm{i}}-$ Inhibition Constant

$K_{\mathrm{M}}$ - Michaelis Constant

$\mathrm{V}_{\max }-$ Maximum Rate

SAR - Structure-Activity Relationship

MMPA - Matched Molecular Pair Analysis

DSC - Differential Scanning Calorimetry

Z-Phe-Arg-AMC - Z-phenylalanine-arginine-7-amido-4-methylcoumarin

Z-Leu-Arg-AMC - Z-Leucine-Arginine-7-Amido-4-methylcoumarin

$k_{\text {cat }}-$ Apparent first-order rate constant (Turnover Number) 


\section{SUMMARY}

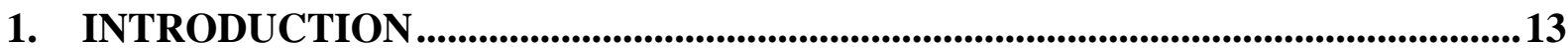

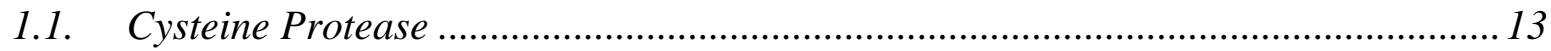

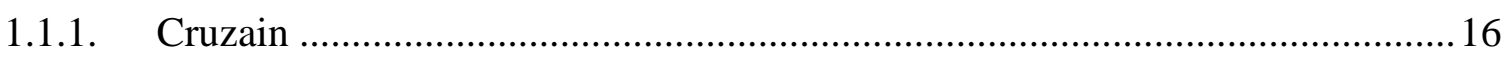

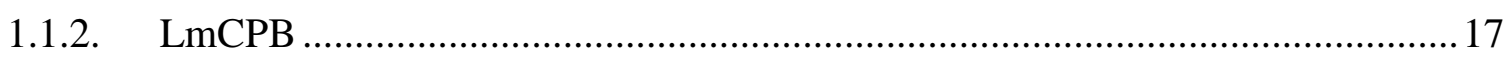

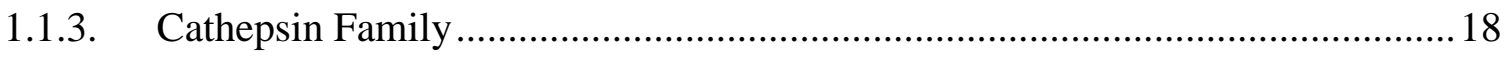

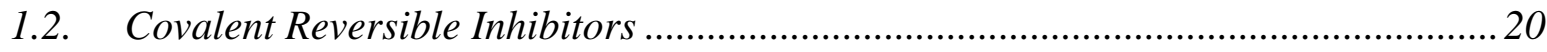

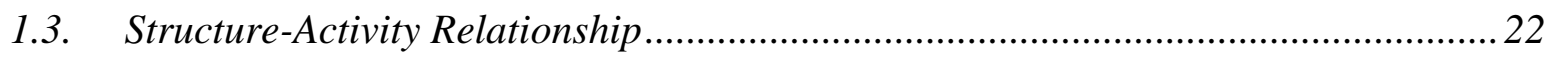

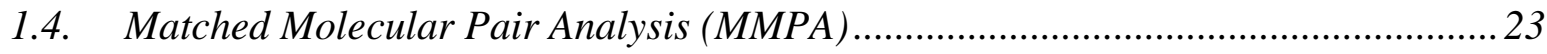

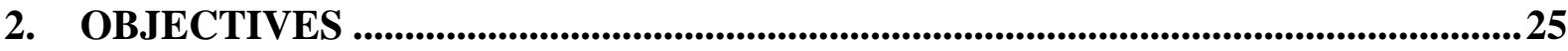

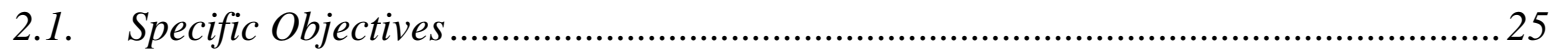

3. MATERIAL AND METHODS

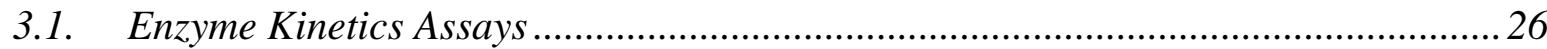

3.1.1. Determination of the Michaelis constant $\left(\mathrm{K}_{\mathrm{M}}\right)$ for Cruzain, $\mathrm{LmCPB}$, and hCatL 26

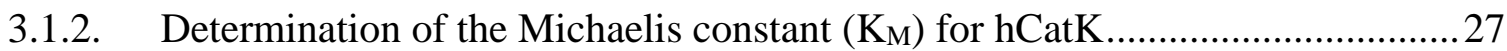

3.1.3. Determination of the Michaelis constant $\left(\mathrm{K}_{\mathrm{M}}\right)$ for hCatS ...............................2 27

3.1.4. Determination of the inhibition constant $\left(\mathrm{K}_{\mathrm{i}}\right)$ for cruzain, $\mathrm{LmCPB}$, hCatL, hCatK,

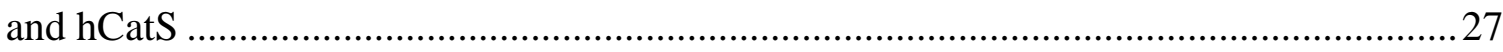

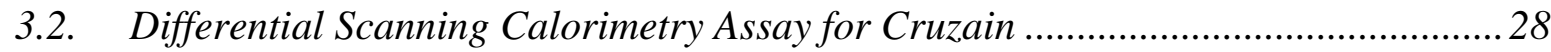

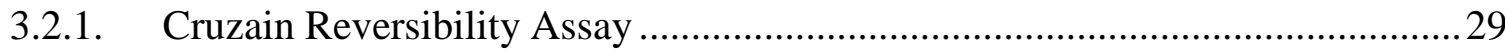

3.2.2. Thermal stability of cruzain with different ligands ..........................................29

4. RESULTS AND DISCUSSION

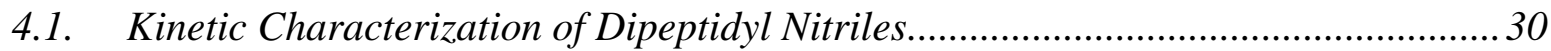

4.2. $\quad M M P / S A R$ analysis of a series of dipeptidyl nitriles ................................................ 33

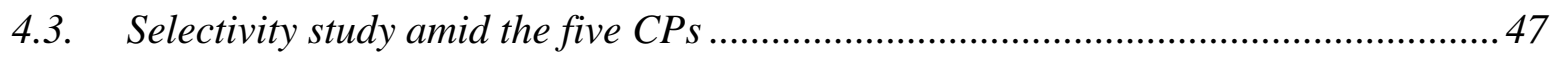

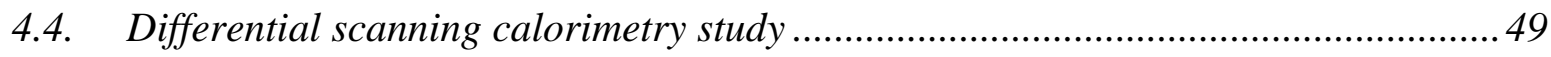

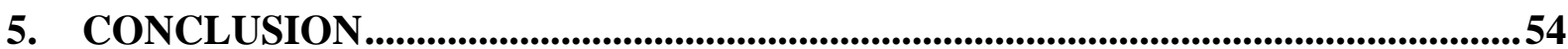




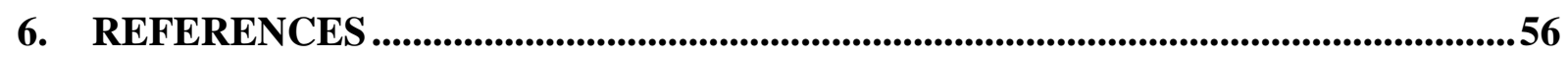

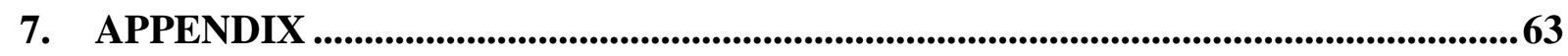

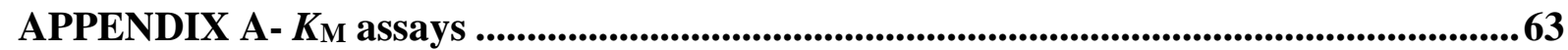

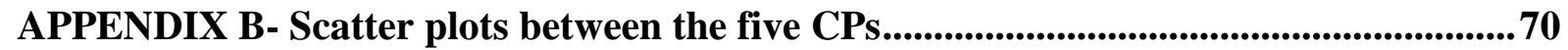

APPENDIX C- Thermal stability study of cruzain against fourteen ligands ..................... 75 


\section{INTRODUCTION}

\subsection{Cysteine Protease}

Proteases (EC 3.4) are a large family of enzymes that hydrolyze peptide bonds in an amino acid sequence through a nucleophilic attack (VERMA; DIXIT; PANDEY, 2016). They are one of the most abundant classes of enzymes, being involved in many biological processes, such as cell-cycle, signaling, and cell death (DEU; VERDOES; BOGYO, 2012). Due to the many processes in which these enzymes are involved, they turned into targets for various types of diseases ranging from cardiovascular disorders to cancer and Alzheimer's disease, as well as for bacterial and infectious diseases ((DEU; VERDOES; BOGYO, 2012; HASANBASIC et al., 2016; KĘDZIOR; SEREDYŃSKI; GUTOWICZ, 2016; MCKERROW, 2018; ROBINSON; DALTON, 2011).

Cysteine proteases (CPs) are found in every living organism (DRAG; SALVESEN, 2010a; SIKLOS; BENAISSA; THATCHER, 2015). The most abundant CPs are papain-like, due to a high homology with the papain structure, a plant protease isolated from Carica papaya (POWERS et al., 2002).

CPs usually have two domains, with the active site being in a cleft between them. The active site consists of three amino acid residues: cysteine (Cys), histidine (His) and asparagine (Asn) (Figure 1). The Cys residue will be activated by the His residue creating an ionic pair that will be stabilized by the Asn residue. The reaction with the substrate will be started through a nucleophilic attack performed by the Cys thiol.

Figure 1: Structural representation of the cysteine protease Falcipain-2 with the active site (in green) in a cleft between the two domains, with the catalytic triad Cys-His-Asn (PDB ID 3PNR).

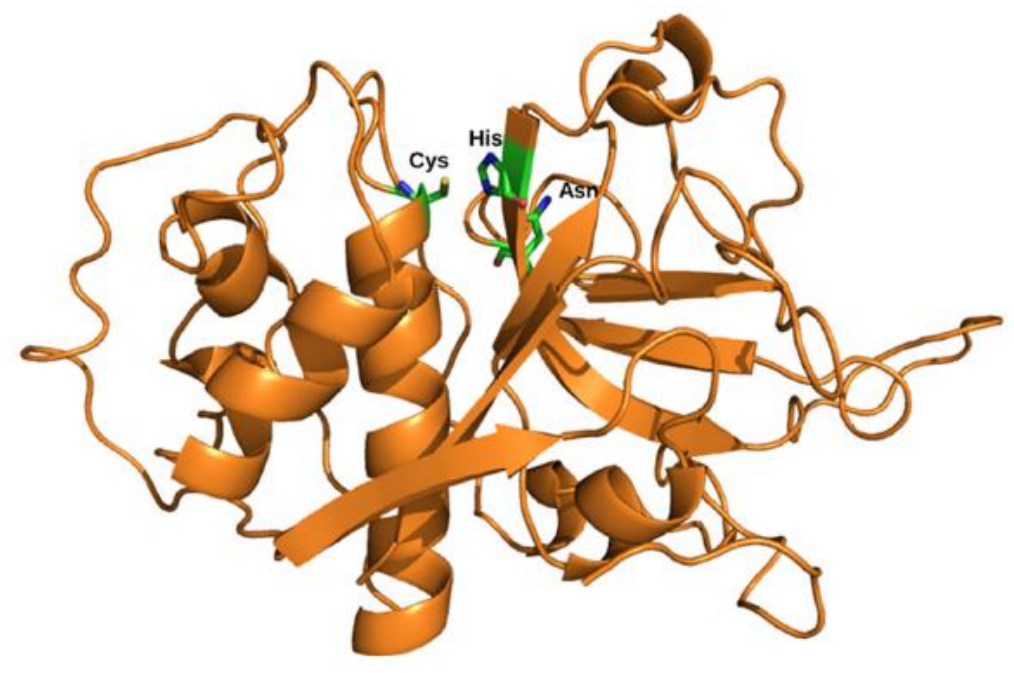


In detail, the mechanism of peptide hydrolysis (Figure 2) initiates with the deprotonation of the thiol group of the Cys by the His residue. Then, the nucleophilic Cys binds the carbonyl carbon of the substrate, forming the first tetrahedral intermediate through an acylation reaction. The intermediate is stabilized by the oxyanion hole, a flexible cavity in the CPs structures, through a hydrogen bond. Afterward, the amino-terminal fragment of the substrate is released, and the His residue is restored to the deprotonated form. The hydrolysis of the acyl-enzyme intermediate occurs and a second tetrahedral intermediate is formed and stabilized by the oxyanion hole. Finally, the carboxylic acid formed is released, reestablishing the active site of the enzyme (ARAFET; FERRER; MOLINER, 2017; POWERS et al., 2002; ZHAI; MEEK, 2018).

Figure 2: Schematic representation of the mechanism of peptide hydrolysis played by cysteine proteases.

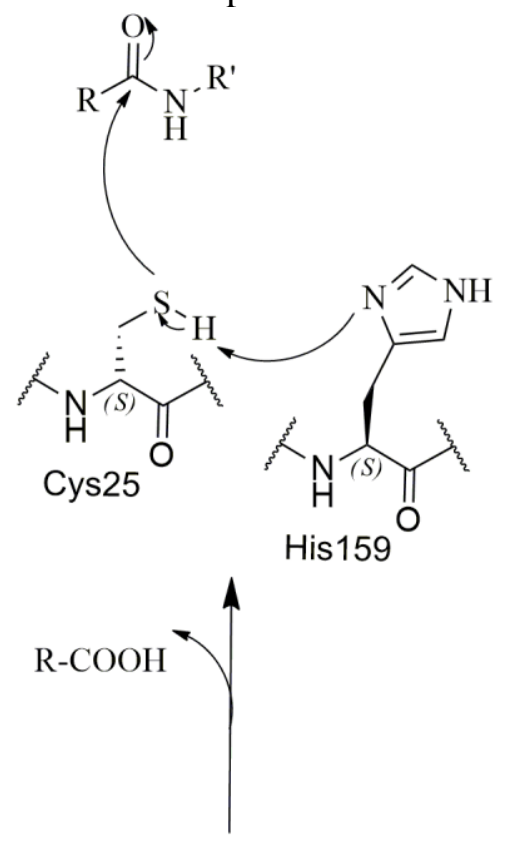

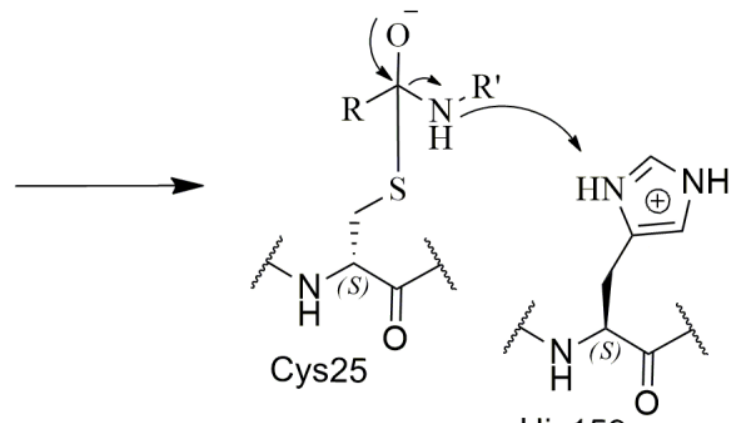

His 159<smiles>[Y]C(O)[Y2](C)=O</smiles>

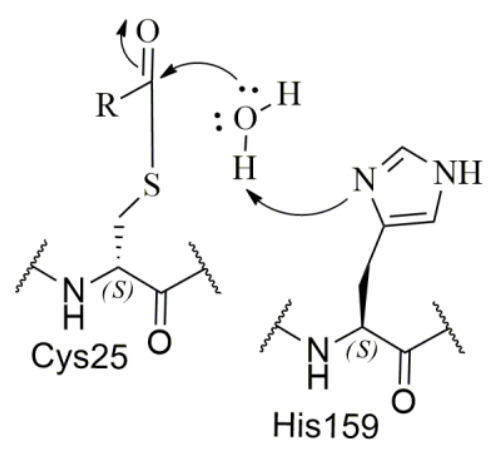

Source: Adapted from ZHAI, X.; MEEK, T. D. Catalytic Mechanism of Cruzain from Trypanosoma cruzi As Determined from Solvent Kinetic Isotope Effects of Steady-State and Pre-Steady-State Kinetics. Biochemistry, v. 57, n. 22, p. 3176-3190, 5 Jun. 2018 
The proteases can recognize their substrates through the peptide sequence or motif that will bind to specific subsites pockets of the active site cleft (Figure 3) (DRAG; SALVESEN, 2010b). In that way, most of the inhibitors design for these enzymes are peptidic substances that interact with specific subsites of the enzyme.

Figure 3: Recognition subsites pockets nomenclature used for proteolytic enzymes. The numbering increase in the direction of the N-terminal residue of the enzyme.

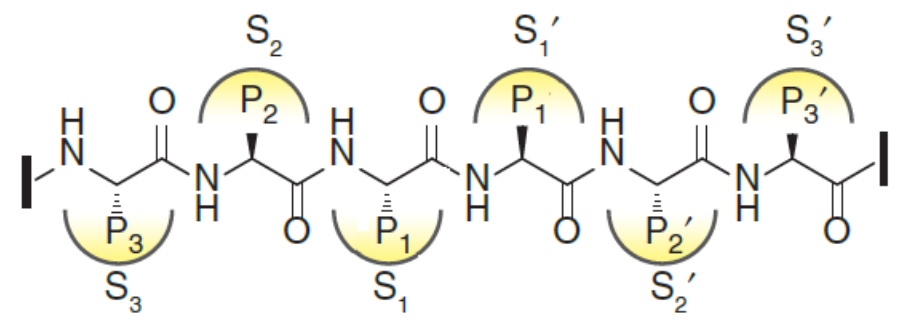

Source: Adapted from SIKLOS, M.; BENAISSA, M.; THATCHER, G. R. J. Cysteine proteases as therapeutic targets: does selectivity matter? A systematic review of calpain and cathepsin inhibitors. Acta Pharmaceutica Sinica B, v. 5, n. 6, p. 506-519, nov. 2015.

Five CPs were studied in this work that present functional structural similarities in which three are mammalian cathepsins: Cathepsin L ( $h$ CatL), Cathepsin S ( $h$ CatS) and Cathepsin K (hCatK), and two protozoa CPs: cruzain $(\mathrm{Cz})$ from Trypanosoma cruzi and Leishmania mexicana CPB ( $L m \mathrm{CPB})$. The human cathepsins are widely studied for being essential targets for cancer and immune system-related diseases (DENNEMÄRKER et al., 2010; STONE et al., 2019). As a result of that, a lot is known of their structures and substrate specificity, having a large number of inhibitors deposited in the ChEMBL data bank (GAULTON et al., 2017).

Protozoan CPs, $\mathrm{Cz}$ and $L m \mathrm{CPB}$ are essential targets for Chagas disease and Leishmaniasis, respectively, which display crucial roles in the life cycle of the parasites. $\mathrm{Cz}$ is a well-established target for Chagas disease, and by that, much is known of its structure. Also there is a significant number of inhibitors deposited in the ChEMBL databank (GAULTON et al., 2017). While for $L m C P B$, little is known of its structure and inhibitors, with only one crystal structure deposited in the PDB databank. However, $L m$ CPB is considered a promising target for the treatment of Leishmania mexicana, the cutaneous form of Leishmania donovani (WILLIAMS et al., 2006).

In that way, these five CPs were studied with 22 inhibitors aiming to identify new hits that display high affinity and selectivity for these enzymes. 


\subsubsection{Cruzain}

Cruzain, also assign as cruzipain (the full-length native enzyme), is the major cysteine protease expressed in the parasite Trypanossoma cruzi (DA SILVA; DO NASCIMENTO PEREIRA; FERREIRA, 2016). $\mathrm{Cz}$ its present in all stages of the parasite life cycle, inducing damage to the host tissue and facilitating the parasite invasion. Therefore, its inhibition interrupts several cellular processes leading to the death of the parasite (ATKINSON; BABBITT; SAJID, 2009; DOYLE et al., 2011; ROGERS et al., 2012).

$\mathrm{Cz}$ is an endopeptidase enzyme that is expressed as a pro-enzyme (BARBOZA et al., 2005). It has two domains (Figure 4), one mostly formed of $\alpha$-helix secondary structure and the other consisting of an extensive $\beta$-sheets interaction. The catalytic triad consists of three amino acid residues, Cys25, His159, and Asn175 (AVELAR et al., 2015; GILLMOR; CRAIK; FLETTERICK, 1997; HERRERA-MAYORGA et al., 2019).

Figure 4: (a) Three-dimensional structure representation of Cruzain bound covalently to a vinyl $\alpha$ ketoester (PDB ID 1U9Q). (b) Cruzain binding site showing the S1, S2 and S3 pocket, covalently bound to a dipeptidyl nitrile (NEQUIMED/IQSC/USP PBD ID 4QH6).
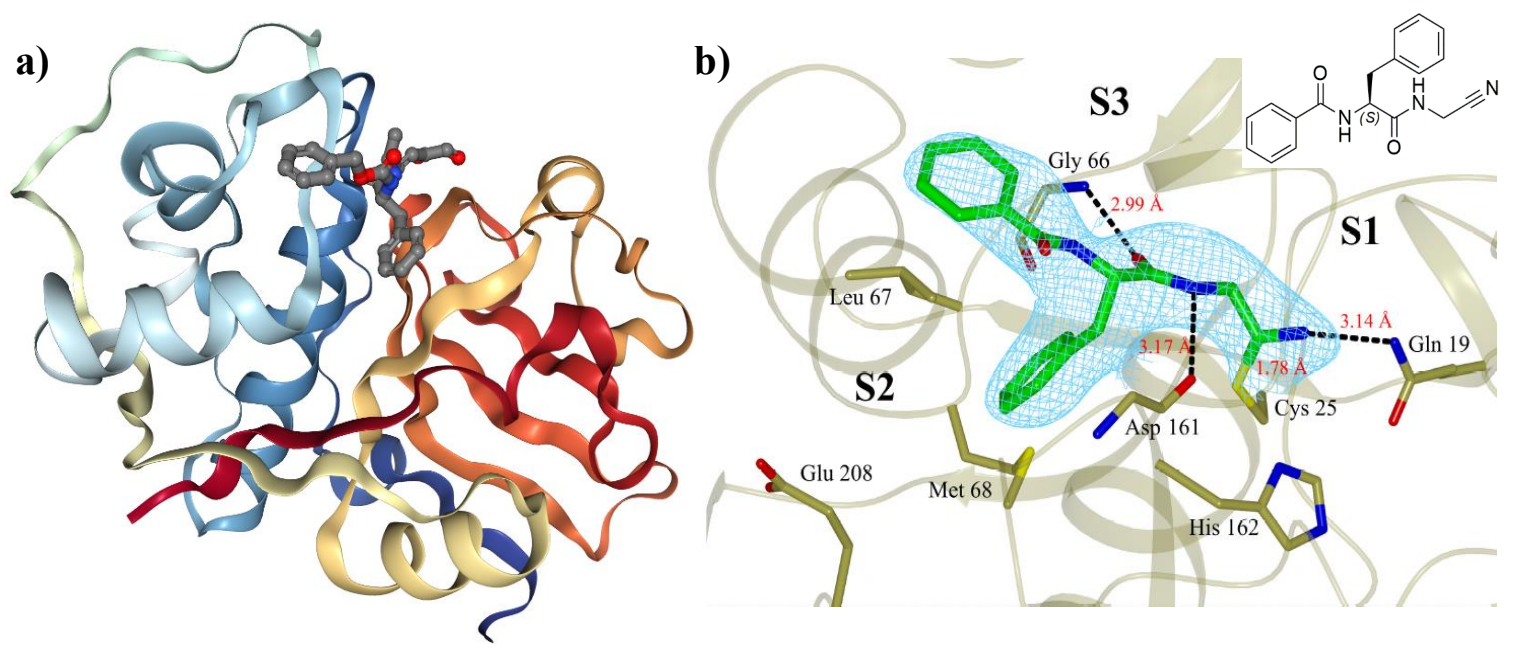

$\mathrm{Cz}$ is a member of the cathepsin L-family, being $h$ CatL like; in that way, it has a high degree of identity with $h$ CatL (ATKINSON; BABBITT; SAJID, 2009). Cz, as the other CPs, has a high preference for noncharged aliphatic or aromatic amino acids side chains, with a hydrophobic characteristic (ROBINSON; DALTON, 2011).

The vinyl sulfone K777 (Figure 5) is one of the most known $\mathrm{Cz}$ irreversible covalent inhibitor. It was first described by the Sandler Center for Research in Tropical Parasitic Diseases (University of California) as a promising drug for the treatment of Chagas disease. 
The compound was active against a wide range of $T$. cruzi strains and reached the preclinical phase without progressing to the next phase, due to high toxicity problems, probably related to its mode of action (MCKERROW et al., 2009; SAJID et al., 2011).

A promising $\mathrm{Cz}$ reversible inhibitor is the $\mathrm{BaCZ007}$ (Figure 5b) that reached the preclinical phase, developed by Beaulie and co-workers. BaCZ007 has a nitrile as warhead and displays a reversible covalent inhibition, different from the K777. Interestingly, the compound exhibit low toxicity, probably due to its reversibility (BEAULIEU et al., 2010).

Figure 5: (a) Covalent irreversible inhibitor K777 structure developed by the University of California and (b) Covalent reversible inhibitor BaCZ007 structure of the Merck pharmaceuticals, both cruzain inhibitors.

a)<smiles>CN1CCN(C(=O)N[C@@H](Cc2ccccc2)C(=O)N[C@H](/C=C\S(=O)(=O)c2ccccc2)CCc2ccccc2)CC1</smiles>

b)<smiles>CC(F)(F)C[C@H](N[C@@H](C(=O)N[C@@H](C#N)Cc1ccccc1F)C(F)(F)F)c1ccc(-c2ccc(S(C)(=O)=O)cc2)cc1</smiles>

Source: Adapted from BEAULIEU, C. et al. Identification of potent and reversible cruzipain inhibitors for the treatment of Chagas disease. Bioorganic \& Medicinal Chemistry Letters, v. 20, n. 24, p. 7444 7449, dez. 2010 and MCKERROW, J. et al. Two approaches to discovering and developing new drugs for Chagas disease. Memórias do Instituto Oswaldo Cruz, v. 104, n. suppl 1, p. 263-269, jul. 2009.

Nitrile class of inhibitors is attractive for research in medicinal chemistry due to their high affinity and low toxicity.

\subsection{2. $\quad \mathrm{LmCPB}$}

LmCPB is one of the three families of CPs genes expressed in the genus Leishmania, along with CPA and CPC. The class b cysteine protease (CPB) is also part of the papain family and has essential involvement in the parasite life cycle in L. mexicana, (MOTTRAM; BROOKS; COOMBS, 1998; SANDERSON et al., 2000). Alongside with CPA, the enzymes display an important role in autophagy and differentiation of promastigotes of the parasite to infective megacycles (WILLIAMS et al., 2006). Recent studies have shown that LmCPB is responsible for cleaving host cell proteins and for causing modifications in cell signaling and 
function of the immune system. This occurs in the promastigote and amastigote stages of the parasite (ABU-DAYYEH et al., 2010).

LmCPB is the recombinant form of the amastigote specific isoform CPB2.8, lacking the C-terminal extension, denominated CPB2.8 $\triangle$ CTE. The enzyme is a typical cathepsin-L-like endopeptidase (DE LUCA et al., 2018). LmCPB is also expressed as a pro-enzyme, and it has two domains structure with a catalytic triad consisting of a Cys26, His164, and Asn184.

This enzyme has only one high resolution X-ray crystallography structure so far. The structure was obtained by the NEQUIMED/IQSC/USP group and co-workers of the University of Nottingham, in which an azanitrile inhibitor is covalently bound to the enzyme. The structure was deposited in the PDB databank with the ID code 6P4E.

LmCPB has only five inhibitors reported in the ChEMBL database, due to that, new studies of this enzyme can have immense contribution in the medicinal chemistry field.

\subsubsection{Cathepsin Family}

The cathepsin family is constituted by 11 members, in which the majority are endopeptidases being all synthesized as zymogens in the human genome. They present a twodomain structure and are also part of the papain-family (KRAMER; TURK; TURK, 2017).

The human cathepsins play chief roles in tumor progression, cardiovascular diseases, osteoporosis and arthritis, neurodegenerative diseases and obesity, making them attractive as drug targets (DENNEMÄRKER et al., 2010; OLSON; JOYCE, 2015; STONE et al., 2019).

The $h \mathrm{CatL}$ is an endosomal/lysosomal CP one of the most expressed cathepsins, which plays a vital role in degrading intracellular proteins. Like the other cathepsins, the enzyme is synthesized as a zymogen, and it is activated in an acidic pH (POREBA et al., 2018). It is known to be involved in tumor invasion and metastasis for many types of cancers like ovarian, breast, prostate, lung, gastric and pancreatic (DENNEMÄRKER et al., 2010; QUILLES JR et al., 2019; TABISH et al., 2019),

$h$ CatK is predominantly expressed in osteoclasts. It is a therapeutic target for bone diseases, such as osteoporosis (STONE et al., 2019; ZAIDI et al., 2001). The $h$ CatK are also involved in atherosclerosis and cancer (MULDER et al., 2014). One of the most promising substances that act as an inhibitor of $h \mathrm{CatK}$ is Odanacatib (Figure 5) that has reached phase III clinical trials (MULLARD, 2016). Another promising drug is the MIV-711 $\left(K_{\mathrm{i}}=0.98 \mathrm{nM}\right) \mathrm{a}$ candidate for the treatment of atherosclerosis developed by the Medivir company. The drug has 
yet no chemical structure published, and it is currently on phase II of clinical trials (CONAGHAN et al., 2018; LINDSTRÖM et al., 2018).

$h \mathrm{CatS}$ is a lysosomal enzyme linked to the modulation of the immune response. It has $57 \%$ of identity with $h \mathrm{CatL}$ and $h \mathrm{CatK}$ but differs with these enzymes by its preference for neutral and slightly basic pH (MCGRATH et al., 1998). $h$ CatS is a therapeutic target for several types of diseases such as multiple sclerosis (FOTI CUZZOLA et al., 2012), psoriasis (AINSCOUGH et al., 2017) and obesity (CHEN et al., 2018). Many inhibitors of this enzyme are in clinical trials; the inhibitor VBY-891, for example, has undergone phase I studies, with positive safety feedback. The structure of this substance is not yet published.

Figure 6: The dipeptidyl nitrile Odanacatib structure, a covalent reversible inhibitor of the human cathepsin $\mathrm{K}$.

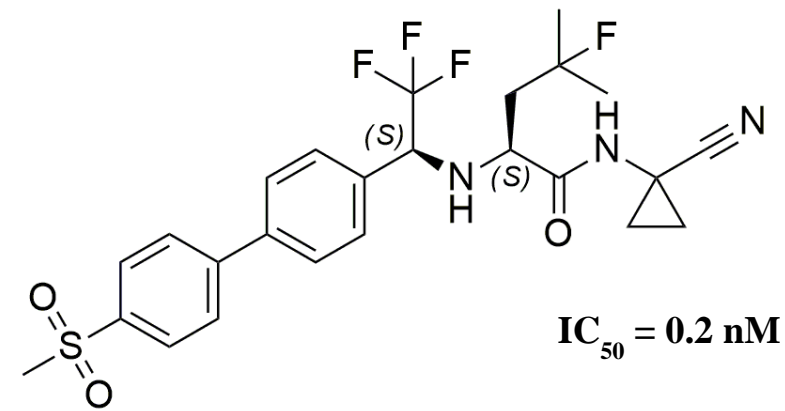

Source: Adapted from MULLARD, A. Merck \& Co. drops osteoporosis drug odanacatib. Nature Reviews Drug Discovery, v. 15, n. 10, p. 669-669, out. 2016.

The human cathepsins L, K, and S, share a high degree of structural homology, with a similar active site region (Figure 6). The sequence forming the S1 subsite for all the three cathepsins is precisely the same, with small changes in their shapes. The S2 and S3 subsites are less conserved. The $\mathrm{S} 2$ subsite for $h \mathrm{CatL}$ and $h \mathrm{CatS}$ have a deep binding pocket, while $h \mathrm{CatK}$ has a small S2 pocket. The three CPs have a preference for hydrophobic residues. 
Figure 7: Crystallographic structure representation of the cathepsins L, K, and S subsites. The PDB ID codes for the enzymes are 2Y2J, $4 \mathrm{X} 6 \mathrm{H}$, and 3OVX, respectively.

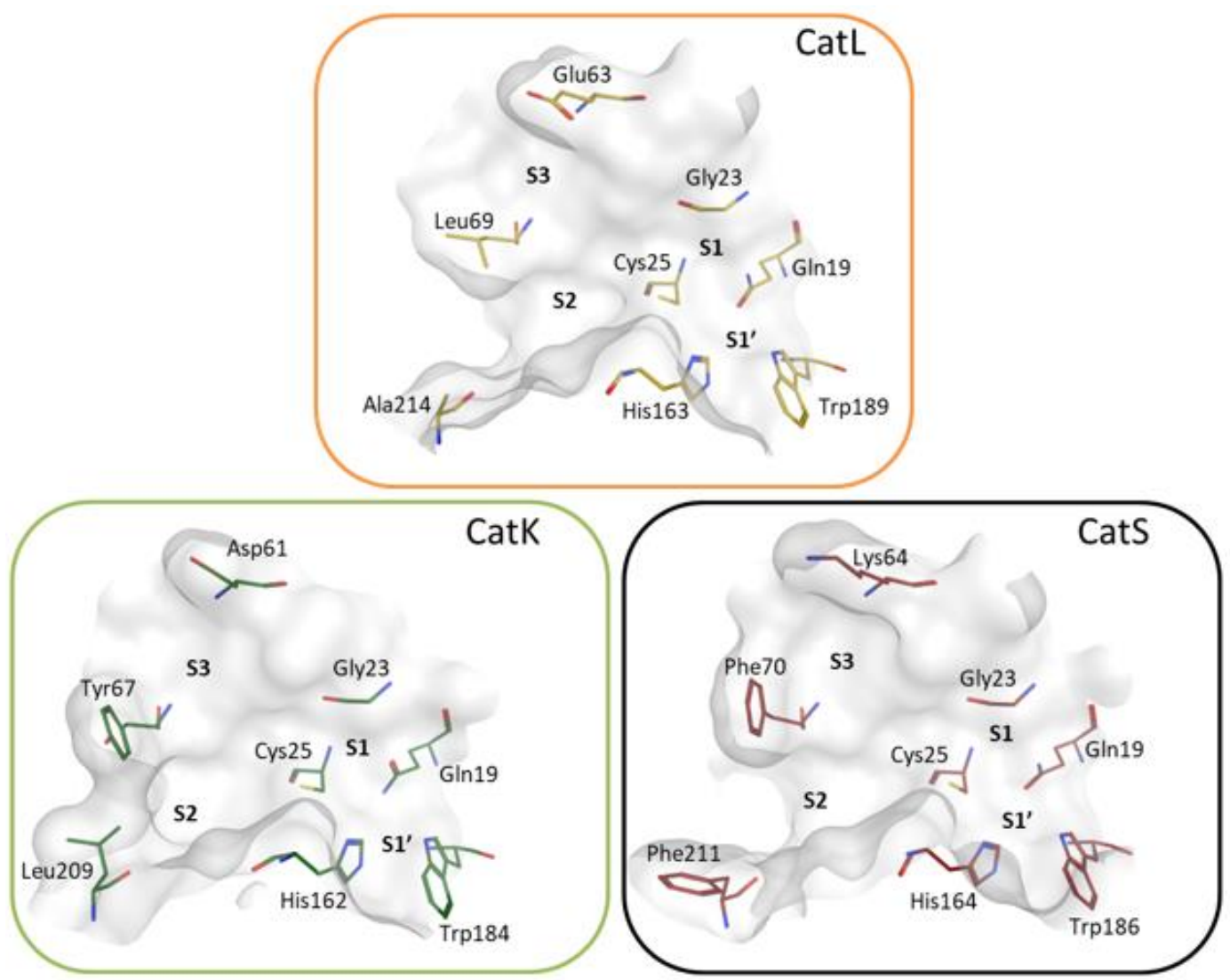

Source: Adapted from CIANNI, L. et al. Can Cysteine Protease Cross-class Inhibitors Achieve Selectivity? Journal of Medicinal Chemistry, 30 jul. 2019.

\subsection{Covalent Reversible Inhibitors}

The CPs are effectively modulated by several classes of covalent inhibitors (CI) due to the presence of the active Cys residue of the enzyme, which facilitates nucleophilic attack to a susceptible electrophile. Examples of successful drugs that act through a covalent mechanism are aspirin and omeprazole (ÁBRÁNYI-BALOGH et al., 2018; SINGH et al., 2011).

CI possesses many advantages over non-covalent compounds, such as high affinity that can be translated into lower and less frequent dosing with decreased potential for off-target effects. Covalent drugs also result in long residence times on the target, which can lead to prolonged action (ÁBRÁNYI-BALOGH et al., 2018; DE CESCO et al., 2017; SMITH et al., 2009).

Covalent inhibitors can bind to the enzyme reversibly or irreversibly, depending on the rate of the reverse reaction (Figure 8). 
Figure 8: Generic mechanism in two-step played by covalent inhibitors, where $\mathrm{E}$ is the target enzyme, I is the inhibitor, E.I is the reversibly bound enzyme-inhibitor complex, and E-I is the formation of a covalent bond between the target and inhibitor.

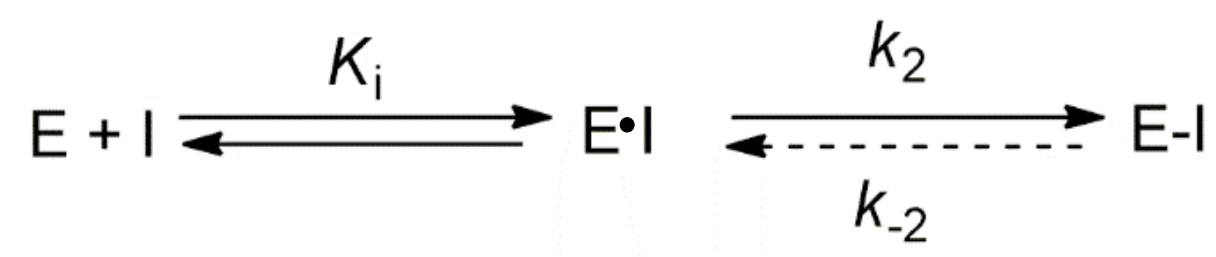

Source: Adapted from STRELOW, J. M. A Perspective on the Kinetics of Covalent and Irreversible Inhibition. SLAS DISCOVERY: Advancing Life Sciences R\&D, v. 22, n. 1, p. 3-20, Jan. 2017.

The $K_{\mathrm{i}}$ (inhibition constant) is the noncovalent binding constant that tells how strong the affinity of the inhibitor for the target is. Reversible covalent inhibitors have a finite value for the constants $k_{2}$ and $k_{-2}$, as for irreversible inhibitors, the $k_{-2}$ will be virtually zero (BAILLIE, 2016; SINGH et al., 2011). For the therapeutic field, reversible inhibitors are more interesting than irreversible ones, due to the high toxicity that sometimes comes along with irreversible drugs.

CI has an electrophilic center responsible for binding to the enzyme known as a warhead. The warhead modulates affinity, selectivity, and the mechanism of inhibition, being an essential moiety for the recognition of the molecule by its target. A wide range of functional groups can be used as warheads (SILVA et al., 2017).

In the present work, a nitrile moiety was used as a warhead. Nitriles are of abundant interest due to its countless versatility, related to the short and polarized triple bond, which makes it possible to go into deep clefts (BERTEOTTI et al., 2014), displaying as well, good metabolic stability (FLEMING et al., 2010). The interaction of this moiety with the CPs involves the $s p$ carbon of the nitrile that will form a reversible covalent bond with the Cys thiol.

A class of inhibitors called dipeptidyl nitrile was used in this work, these compounds are known to be CPs inhibitors for decades, presenting good inhibitory activity and selectivity (AVELAR et al., 2015; OTTO; SCHIRMEISTER, 1997).

A dipeptidyl nitrile scaffold (Figure 9a) was designed considering the recognition sites for proteolytic enzymes. The aim was to determine which variations in P1, P2, and P3 (Figure $9 b)$, lead to a higher affinity with the targets. 
Figure 9: (a) Dipeptidyl nitrile scaffold with the nitrile group as a warhead. (b) Neq0570 and the mode of interaction with the binding site of the CP.

a)

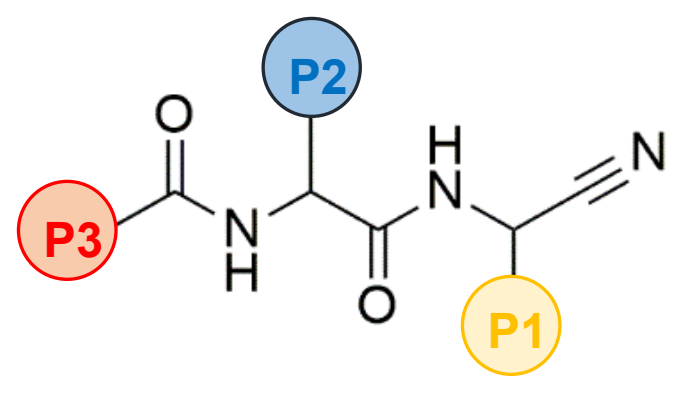

b)

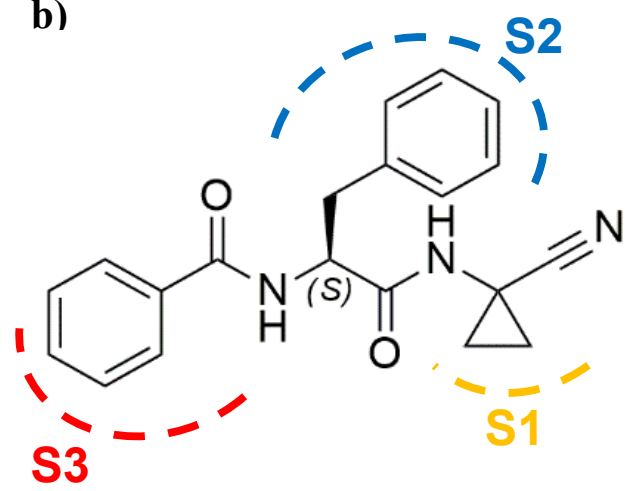

Source: Own author

The substances used in this work will be analyzed by their affinity, through the analysis of the structural-activity relationship and by comparison between the dot structure modifications in pairs of molecules.

\subsection{Structure-Activity Relationship}

Drug discovery is a multidisciplinary area, in which compounds need to be optimized for several reasons, which includes affinity improvement, bioavailability, safety, among other properties before they become a promising drug candidate. One way to optimize compounds is by using structure-activity relationship (SAR) analysis.

SAR is the relationship between the chemical or 3D structure of a molecule and its biological activity. SAR is a fundamental analysis in drug discovery, from primary screening to lead optimization and can be divided into two groups - those based on regression models (QSAR) and those based on physicochemical approaches (GUHA, 2013). An understanding of the SAR for a set of compounds, allows one to elucidate the chemical space of the desired molecule and use that information for further optimization regarding physicochemical properties or activity/selectivity index (GUHA, 2013; WAWER; BAJORATH, 2011).

In a research conducted by the NEQUIMED/IQSC/USP group at the University of São Paulo (USP), a SAR study was conducted for some $\mathrm{Cz}$ inhibitors. Several structural modifications at the $\mathrm{P} 2$ and $\mathrm{P} 3$ positions were performed in a dipeptidyl nitrile scaffold (Figure 10). The modifications led to a compound with over 100 fold higher affinity toward $\mathrm{Cz}$ than the prototypical compound, providing information about the enzyme preferences in the S2 and S3 pocket (AVELAR et al., 2015). 
Figure 10: Structural representation of a dipeptidyl nitrile as cruzain covalent reversible inhibitor used for SAR studies, with the positions were structural modifications occurred market as blue (P2) and red (P3) in the molecule structure.

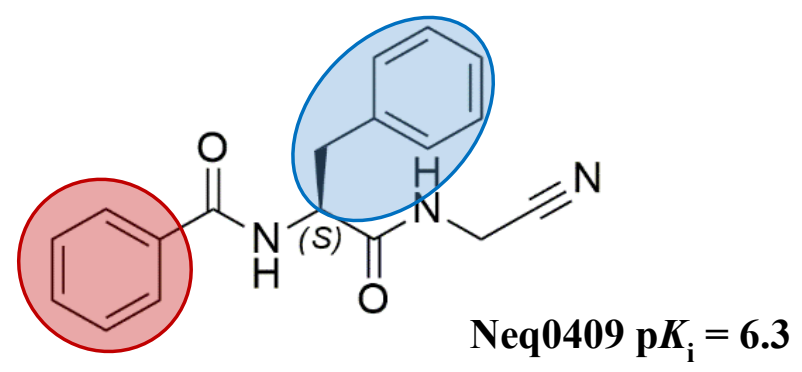

Source: Adapted from AVELAR, L. A. A. et al. Molecular Design, Synthesis and Trypanocidal Activity of Dipeptidyl Nitriles as Cruzain Inhibitors. PLOS Neglected Tropical Diseases, v. 9, n. 7, p. e0003916, 14 Jul. 2015

\subsection{Matched Molecular Pair Analysis (MMPA)}

MMPA is a concept that seeks to evaluate substances properties associated with a single located structural change, as exemplified in Figure 11 (GRIFFEN et al., 2011). The substructure shared between MMP partners is called key fragment, and the substructures that are different are called value fragment. If this change in the affinity, commonly expressed as $\mathrm{p} K_{\mathrm{i}}$ values, corresponds to be equal or higher than $2.0 \mathrm{log}$ units, matched molecular pairs (MMPs) are called activity cliffs. If no meaningful change ( $\Delta \mathrm{p} K_{\mathrm{i}} \pm 0.2 \log$ units) is present, such pairs are called bioisosteres (FUCHS et al., 2015; KRAMER et al., 2014; STUMPFE; BAJORATH, 2012).

Figure 11: MMPA for two dipeptidyl nitrile inhibitors of Cathepsin B, where a change, shown in red, for the compound (1) from the compound (2), in orange, exhibit a difference in the activity of $1.0 \mathrm{log}$ unit.

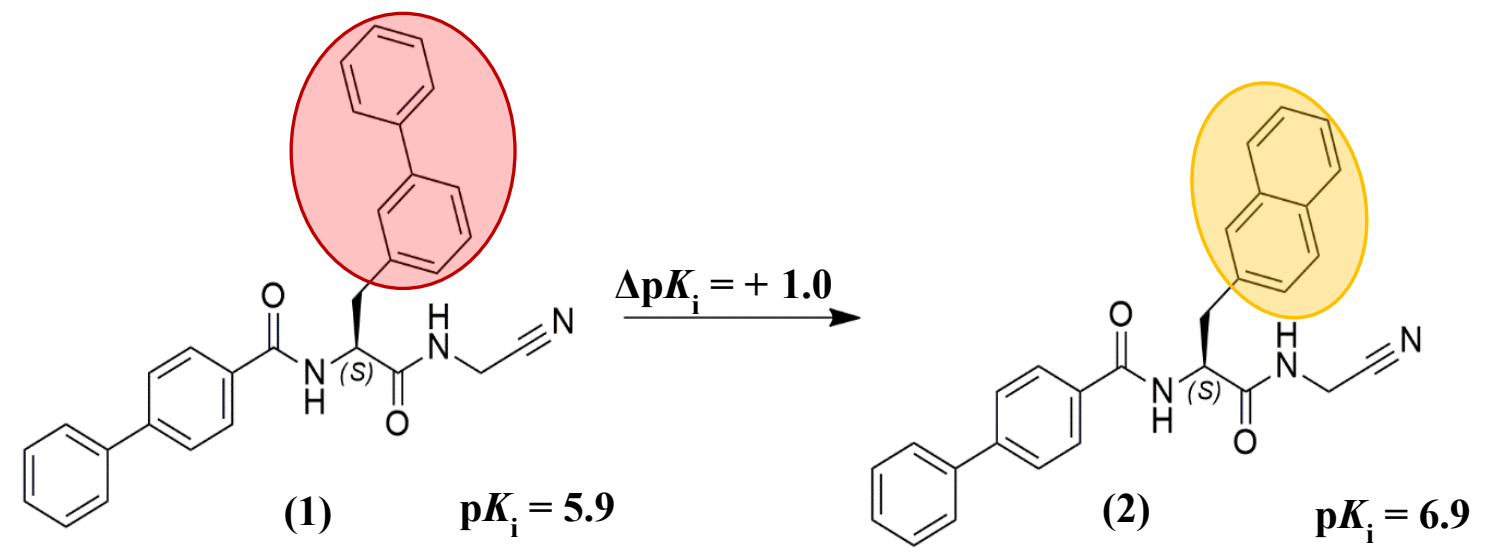

Source: Adapted from SCHMITZ, J. et al. Cathepsin B Inhibitors: Combining Dipeptide Nitriles with an Occluding Loop Recognition Element by Click Chemistry. ACS Medicinal Chemistry Letters, v. 7, n. 3, p. 211-216, 10 Mar. 2016. 
The relationships between MMPs may be simple, as a hydrogen atom change for a chlorine atom, or more complex involving a significant change in some part of the molecule (BIRCH et al., 2009). Despite the structural changes, MMPA results also depend on the chemical environment. The chemical properties of an atom/group can have a pronounced impact on the effect of the chemical transformation (KRAMER et al., 2014; PAPADATOS et al., 2010)

A crucial role of the MMPA is its use in the optimization of molecules aiming to obtain a relationship between structure and activity (SAR), having an advantage of dealing directly with measured data, providing clear understanding and interpretation of the results (GRIFFEN et al., 2011).

In the present work, the affinity of a large number of inhibitors was determined using a fluorimeter, in which the $\mathrm{p} K_{\mathrm{i}}$ values were obtained. We were able to use similar protocols for the five CPs making a fast and efficient determination of the constants.

Furthermore, a study using the differential scanning calorimetry (DSC) technique was performed with $\mathrm{Cz}$. The technique allows one to identify the temperature in which the protein is $50 \%$ in the folded form and $50 \%$ unfolded $(\mathrm{Tm})$ by heating the protein solution at constant pressure. Along with the Tm determination, the $\Delta \mathrm{Cp}$ and $\Delta \mathrm{H}$ of the process of unfolding are also determined. Therefore, the thermal stability investigation of $\mathrm{Cz}$ was performed in the presence of some of the bests inhibitors in this work, using DSC, seeking to evaluate the magnitude of stabilization $(\Delta \mathrm{Tm})$ of the $\mathrm{Cz}$ structure when incubated with the ligands. 


\section{OBJECTIVES}

The main goal of this work is to evaluate the affinity of 22 covalent reversible inhibitors with a dipeptidyl nitrile scaffold against five cysteine proteases of the papain family, being two from parasites and three from mammalians. Additionally, characterize the thermal unfolding of cruzain, as well as to evaluate the thermal stabilization of its structure in the presence of different ligands by differential scanning calorimetry (DSC).

\subsection{Specific Objectives}

I. Determine the inhibition constants $\left(K_{\mathrm{i}}\right)$ for a range of covalent reversible inhibitors against cruzain, $L m C P B$, and $h \mathrm{CatL}$ using a fluorimetric technique.

II. Select some inhibitors based on their structures similarities with a $\mathrm{p} K_{\mathrm{i}}$ equal or higher than 7.0, which are going to be tested against $h$ CatS and $h$ CatK.

III. Analyze the chosen compounds relating their structures and activities with the five CPs.

IV. Study the thermal unfolding of cruzain.

V. Study the thermal unfolding of cruzain in the presence of ligands. 


\section{MATERIAL AND METHODS}

The enzymes cruzain and $L m C P B$ were expressed in the NEQUIMED/IQSC/USP laboratories by Ms. Fabiana Rosini and Dr. Jean F. R. Ribeiro, respectively. The synthesis of the inhibitors used in this work was performed by Ms. Lorenzo Cianni, Dr. Daniela de Vita, and Dr. Anwar Shamin.

All reagents and solvents were purchased from the companies Sigma-Aldrich, CombiBlocks, and Bachem. No prior procedures of purification were performed. The human enzymes Cathepsin-L, Cathepsin-S, and Cathepsin-K, were purchased from the companies SigmaAldrich and Enzo Life Sciences.

The computer software used to analyze the fluorimeter (spectroscopic technique) and the DSC data were the Microsoft Excel, Gen5 ${ }^{\mathrm{TM}}$ Biotek®, SygmaPlot 10, Origin 8.5 and Nano Analyze.

\subsection{Enzyme Kinetics Assays}

The assays were conducted with the fluorimeter equipment Biotek Synergy HT system, in which the rate of hydrolysis of the fluorogenic substrates Z-Phe-Arg-AMC (Sigma-Aldrich/ Combi-Blocks) and Z-Leu-Arg-AMC (Bachem) were monitored for five enzymes. Different protocols were used in the assays, as reported below.

\subsection{1. $\quad$ Determination of the Michaelis constant $\left(K_{M}\right)$ for Cruzain, LmCPB, and hCatL}

The enzyme kinetics assays were done at $25{ }^{\circ} \mathrm{C}$ using a 96-well black microplate (Corning®) with an excitation wavelength of $360 \mathrm{~nm}$ and an emission wavelength of $460 \mathrm{~nm}$. The enzymes were activated with an assay buffer $100 \mathrm{mM}$ sodium acetate $\mathrm{pH}$ 5.5, $300 \mathrm{mM}$ of $\mathrm{NaCl}$ and $5 \mathrm{mM}$ of EDTA (Sigma-Aldrich), containing $7 \mathrm{mM}$ DTT (Sigma-Aldrich), $0.014 \%$ of Triton X-100 (Sigma-Aldrich), in an ice bath between 15-20 minutes, depending on the enzyme. The concentrations used for the enzymes were $0.15 \mathrm{nM}, 7 \mathrm{nM}$ and $1.9 \mathrm{nM}$ for cruzain, $L m C P B$ and $h$ CatL (Sigma-Aldrich/Enzo Life Sciences), respectively. The reaction rate was followed for $5 \mathrm{~min}$ in the fluorimeter, in which the rate of hydrolysis of the substrate Z-PheArg-AMC was monitored. It was used a final concentration of DMSO (Sigma-Aldrich) of $5 \%$ 
$(10 \mu \mathrm{L})$ in each well. The assays were performed in triplicates. It was used eight different substrate concentrations, prepared with a 0.5 dilution factor.

\subsubsection{Determination of the Michaelis constant $\left(K_{M}\right)$ for hCatK}

Human recombinant Cat-K (Enzo Life Sciences) was assayed at $25{ }^{\circ} \mathrm{C}$ using a 96-well black microplate with an excitation wavelength of $360 \mathrm{~nm}$ and an emission wavelength of 460 $\mathrm{nm}$. The enzymes were activated at $37^{\circ} \mathrm{C}$ (SANYO $\mathrm{CO}_{2}$ incubator) for 30 minutes in the assay buffer $100 \mathrm{mM}$ sodium acetate $\mathrm{pH} 5.5,300 \mathrm{mM}$ of $\mathrm{NaCl}$ and $5 \mathrm{mM}$ of EDTA, containing $7 \mathrm{mM}$ DTT, $0.014 \%$ of Triton X-100. The concentration of the enzyme was $0.15 \mathrm{nM}$. The reaction rate was followed for $5 \mathrm{~min}$ in the fluorimeter, in which the rate of hydrolysis of the substrate Z-Leu-Arg-AMC was monitored. It was used a final concentration of DMSO of $5 \%(10 \mu \mathrm{L})$ in each well. The assay was performed in triplicates. It was used eight different substrate concentrations, prepared with a 0.5 dilution factor.

\subsection{3. $\quad$ Determination of the Michaelis constant $\left(K_{M}\right)$ for hCatS}

Human recombinant Cat-S (Enzo Life Sciences) was assayed at $25^{\circ} \mathrm{C}$ using a $96-w e l l$ black microplate with an excitation wavelength of $360 \mathrm{~nm}$ and an emission wavelength of 460 $\mathrm{nm}$. The enzymes were activated with an assay buffer $100 \mathrm{mM}$ sodium citrate $\mathrm{pH} 6.0,50 \mathrm{mM}$ of $\mathrm{NaCl}$ and $2 \mathrm{mM}$ of EDTA, containing $7 \mathrm{mM}$ DTT, $0.014 \%$ of Triton X-100, and it was then incubated at $37^{\circ} \mathrm{C}$ for 60 minutes. The concentration of the enzyme was $1.12 \mathrm{nM}$. The reaction rate was followed for $5 \mathrm{~min}$ in the fluorimeter, in which the rate of hydrolysis of the substrate Z-Phe-Arg-AMC was monitored. It was used a final concentration of DMSO of $5 \%(10 \mu \mathrm{L})$ in each well. The assay was performed in triplicates. It was used eight different substrate concentrations, prepared with a 0.5 dilution factor.

\subsubsection{Determination of the inhibition constant $\left(K_{i}\right)$ for cruzain, $L m C P B$, hCatL, hCatK, and hCatS}

The inhibition constants were determined through an indirect test, in which substrate and inhibitor are in the same solution of the enzyme. It was used a competitive inhibition protocol; the experiment was already done by previous members of the NEQUIMED/IQSC/USP group (CIANNI et al., 2018). 
For enzymes activation steps and enzymes concentrations, it was used the same protocol described above (section 3.1). The substrates concentration used in the assay was fixed and equal to the $K_{\mathrm{M}}$, so $[\mathrm{S}]=K_{\mathrm{M}}$.

The initial concentrations of the inhibitors varied from 50 to $0.01 \mu \mathrm{M}$, in which seven solutions were prepared in DMSO with a 0.5 dilution factor. Negative control was performed with DMSO. The experiment was done in triplicates. The final concentration of DMSO in each well was $5 \%$.

The inhibitors were incubated with the enzyme solution for 2 minutes before the reaction started by the addition of the substrate.

The apparent inhibition constant of the inhibitors was calculated using a non-linear adjustment of the data, where $v_{\mathrm{s}}$. is the steady-state velocity, $v_{0}$ is the velocity in the absence of inhibitor and $[\mathrm{I}]$ is the inhibitor concentration.

$$
v_{S}=\frac{v_{0}}{\frac{1+[I]}{K_{i}^{a p p}}} \quad \text { Equation } 2
$$

The actual inhibition constant $K_{\mathrm{i}}$ was determined by the correction of $\mathrm{K}_{\mathrm{i}}^{\mathrm{app}}$, using the Cheng and Prusoff (YUNG-CHI; PRUSOFF, 1973) equation. Substrates concentrations were equal to the $\mathrm{K}_{\mathrm{M}}$ value.

$$
K_{\mathrm{i}}=\frac{K_{\mathrm{i}}^{\mathrm{app}}}{1+\frac{[\mathrm{S}]}{[\mathrm{KM}]}} \quad \rightarrow \quad K_{\mathrm{i}}=\frac{K_{\mathrm{i}}^{\mathrm{app}}}{2} \quad \text { Equation } 3
$$

The assays were conducted, if necessary, until a higher concentration of $50 \mu \mathrm{M}$ for weak inhibitors. When the $\mathrm{p} K_{\mathrm{i}}$ value was lower than 5.0 the results were displayed as a percentage of inhibition, which is equal to the RFU s ${ }^{-1}$ obtained for the highest inhibitor concentration divided by the RFU s ${ }^{-1}$ obtained for the blank sample.

\subsection{Differential Scanning Calorimetry Assay}

The thermal stability assay was carried out for cruzain. The Tm, temperature in which half of the protein is in the folded and unfolded form, were determined along with the $\Delta \mathrm{H}_{\mathrm{Tm}}$. The experiment was performed in a differential scanning calorimetry- Nano DSC of the TA Instruments. The instrument consists of two cells with a $600 \mu \mathrm{L}$ of capacity, being one for the sample solution and the other for the reference. 
Cruzain was thawed at room temperature for approximately 5 minutes. After that, the protein was added in a dialysis membrane (Amicon Ultra) of $15 \mathrm{~mL}$ and $10 \mathrm{kDa}$, along with a buffer solution of $100 \mathrm{mM}$ sodium acetate, $300 \mathrm{mM}$ of $\mathrm{NaCl}$ and $5 \mathrm{mM}$ of EDTA pH 5.5 and 1 $\mathrm{mM}$ of $\beta$-mercaptoethanol (Sigma-Aldrich). The solution was centrifuged (Eppendorf 5804R) at $4500 \mathrm{rcf}$ at $4{ }^{\circ} \mathrm{C}$ for 35 minutes. Afterward, the solution was transferred to a micro centrifuge tube and kept on ice. The $\mathrm{Cz}$ concentration was measured in $\mathrm{mg} \mathrm{mL}^{-1}$ using a DeNovixDS-11+ spectrometer; the measurement was repeated three times.

The samples for the reversibility assay were prepared with a final volume of $1000 \mu \mathrm{L}$. The sample solution was prepared with a $\mathrm{Cz}$ concentration of $30 \mu \mathrm{M}\left(0.7 \mathrm{mg} \mathrm{mL}^{-1}\right)$, acetate buffer $\mathrm{pH} 5.5,0.014 \% \mathrm{v} / \mathrm{v}$ of Triton X-100, and $5 \%$ of DMSO. The reference cell was prepared with the acetate buffer $\mathrm{pH} 5.5,0.014 \% \mathrm{v} / \mathrm{v}$ of Triton X-100, and $5 \%$ of DMSO. Both samples were degassed for 5 minutes before being added in the equipment cells.

The experiment was performed with sequential scans at $3 \mathrm{~atm}$ and with a rate of 2 ${ }^{\circ} \mathrm{C} / \mathrm{min}$. First, the sample was heated from 0 to 90 degrees, then it was cooled to $0{ }^{\circ} \mathrm{C}$ and again heated to $90{ }^{\circ} \mathrm{C}$. The experiment was performed in duplicates.

\subsection{2. $\quad$ Thermal stability of cruzain with different ligands}

The dialysis of the protein was made in the same way described before. The samples were prepared with a final volume of $1000 \mu \mathrm{L}$. The sample solution was prepared with a $\mathrm{Cz}$ concentration of $30 \mu \mathrm{M}\left(0.7 \mathrm{mg} \mathrm{mL}^{-1}\right)$, acetate buffer $\mathrm{pH} 5.5,0.014 \% \mathrm{v} / \mathrm{v}$ of Triton X-100, 5 $\%$ of DMSO and with a ligand concentration of $120 \mu \mathrm{M}$. The reference cell was prepared with the acetate buffer $\mathrm{pH} 5.5,0.014 \% \mathrm{v} / \mathrm{v}$ of Triton X-100, and $5 \%$ of DMSO. Both samples were degassed for 5 minutes before being added in the equipment cells.

The blank was made for all the compounds, where the protein was removed from the sample cell. The experiment was performed in duplicates.

The experiment was performed with a single scan at 3 atm and with a rate of $2{ }^{\circ} \mathrm{C} / \mathrm{min}$, where the samples were heated, ranging from $0{ }^{\circ} \mathrm{C}$ to $90{ }^{\circ} \mathrm{C}$. 


\section{RESULTS AND DISCUSSION}

\subsection{Kinetic Characterization of Dipeptidyl Nitriles}

In order to evaluate the activity of the five CPs, the $K_{\mathrm{M}}$ and $\mathrm{V}_{\max }$ were determined through the Michaelis-Menten equation. In the assays, two different substrates were used, the Z-Phe-Arg-AMC and Z-Leu-Arg-AMC (Figure 12). Both substrates are fluorogenic due to the presence of a coumarin moiety. Through a hydrolysis reaction, the substrate is cleaved by the enzyme which releases the 7-amino-4-methylcoumarin fluorescent group.

Figure 12: Structures of the substrates Z-Phe-Arg-AMC (a) and Z-Leu-Arg-AMC (b) with their structural differences highlighted in red at the P2 position. The guanidine group $\left(\mathrm{p} K_{\mathrm{a}}=12.5\right)$ of the arginine, present in both substrates, is protonated under the assay conditions $(\mathrm{pH}=5.5)$.

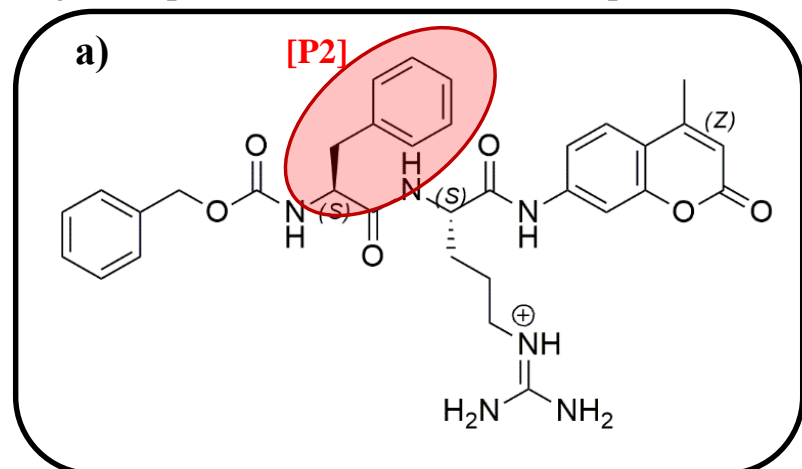

b)

Source: Own author

For $\mathrm{Cz}, \mathrm{LmCPB}, h \mathrm{CatL}$, and $h \mathrm{CatS}$ the substrate Z-Phe-Arg-AMC was used, while ZLeu-Arg-AMC was used for $h \mathrm{CatK}$. The main reason for the use of the two substrates lays in the differences in the $\mathrm{S} 2$ pocket of these CPs. $\mathrm{Cz}, \mathrm{LmCPB}, h \mathrm{CatL}$, and $h \mathrm{CatS}$ have a deep mainly hydrophobic S2 pocket. So, the Z-Phe-Arg-AMC bearing Phenylalanine in P2 has moderate to high affinity for these CPs. On the other hand, $h$ CatK has a smaller S2 pocket and it privileges Leucine or Isoleucine as amino acid in P2.

The protocols also varied in the time and temperature of activation, for $\mathrm{Cz}, \operatorname{LmCPB}$, and $h$ CatL the activation occurred in an ice bath in an interval of 10 to 20 minutes. $h$ CatK and $h$ CatS were activated at $37^{\circ} \mathrm{C}$ taking about 30 to 60 minutes (FRIZLER et al., 2011).

Two different $\mathrm{pHs}$ were used in the assays, one being $\mathrm{pH} 5.5$ and the other 6.0. Because the activation of $\mathrm{Cz}, L m \mathrm{CPB}, h \mathrm{CatL}$ and $h \mathrm{CatK}$ occurs in slightly acidic media, the $\mathrm{pH}$ chosen for the assays was 5.5. $h$ CatS have an optimum $\mathrm{pH}$ between 6.0 and 7.5, so the $\mathrm{pH} 6.0$ was chosen for the assays (TURK et al., 2012). 
The Michaelis-Menten plot was obtained for the five CPs having the rate of the reaction $\left(\mu \mathrm{mol} \mathrm{g} \mathrm{g}^{-1}\right)$ in the $\mathrm{y}$-axis and concentration $(\mu \mathrm{M})$ in the $\mathrm{x}$-axis, as shown in Figure $13 \mathrm{for} \mathrm{Cz}$.

Figure 13: Velocity plot as a function of Z-Phe-Arg-AMC concentration for cruzain fit in the MichaelisMenten equation.

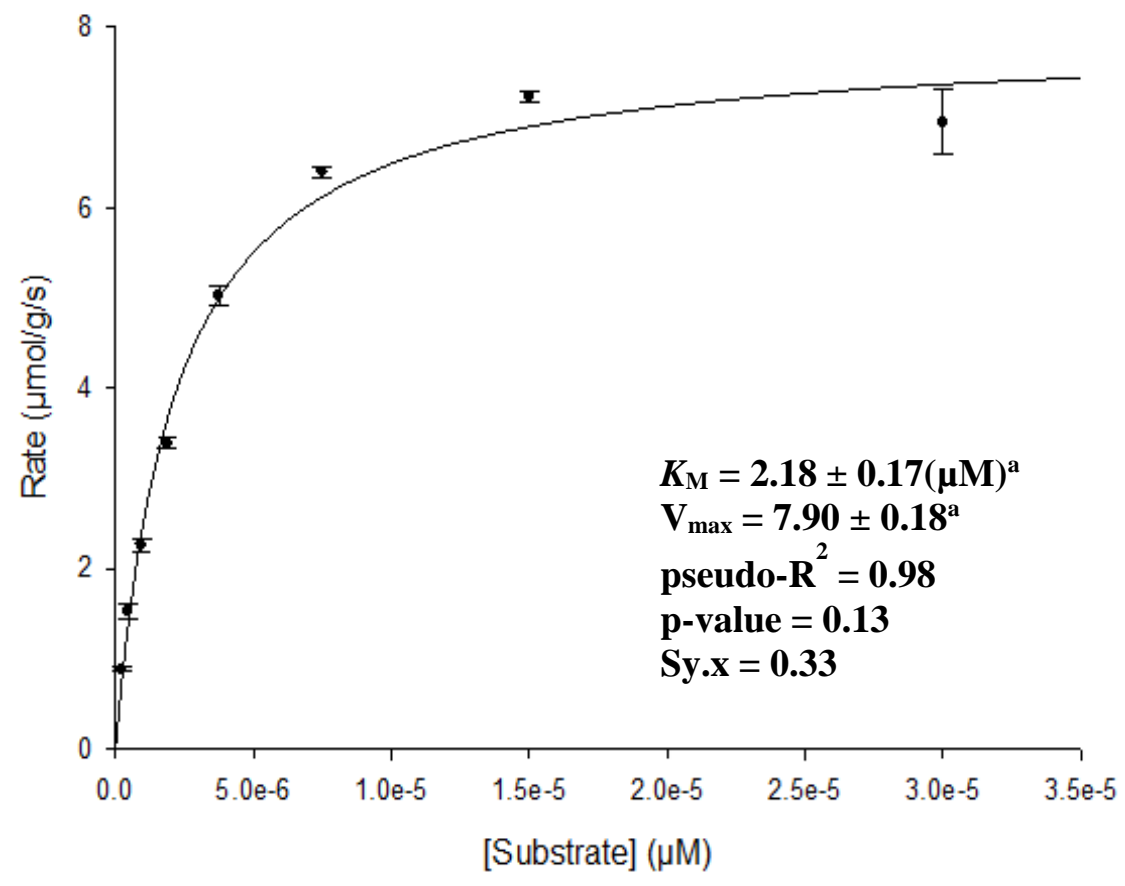

${ }^{a}$ Obtained using $v=\frac{V_{\max }[S]}{K_{M}+[S]}$

The $K_{\mathrm{M}}$ and $\mathrm{V}_{\max }$ obtained for all the CPs are shown in Table 1, every assay was done in triplicate and at least twice. The plots can be seen in Appendix A.

Table 1: $K_{\mathrm{M}}$ and $\mathrm{V}_{\max }$ results for the five CPs obtained through the Michaelis-Menten equation. The experimental $K_{\mathrm{M}}$ results showed at BRENDA ${ }^{\mathrm{a}}$ website for $\mathrm{Cz}$ is 1 to $3 \mu \mathrm{M} ; \mathrm{LmCPB} 5$ to $17 \mu \mathrm{M} ; h \mathrm{CatL}$ $=0.7$ to $6 \mu \mathrm{M} ; h \mathrm{CatS}=14$ to $42 \mu \mathrm{M} ; h \mathrm{CatK}$ is 1.5 to $4.6 \mu \mathrm{M}$.

\begin{tabular}{ccccc} 
Enzyme & $\boldsymbol{K}_{\mathbf{M}}(\boldsymbol{\mu M})$ & $\mathbf{V}_{\mathbf{m a x}}\left(\boldsymbol{\mu m o l} \mathbf{~ g}^{-\mathbf{1}} \mathbf{s}^{\mathbf{- 1}}\right)$ & $\boldsymbol{k}_{\text {cat }}\left(\mathbf{s}^{\mathbf{- 1}}\right)$ & $\boldsymbol{k}_{\text {cat }} / \boldsymbol{K}_{\mathbf{M}}\left(\mathbf{M}^{\mathbf{- 1}} \mathbf{s}^{\mathbf{- 1}}\right)$ \\
\hline Cruzain $^{\mathrm{b}}$ & $1.8 \pm 0.2$ & $7.4 \pm 0.6$ & $0.2 \pm 0.01$ & $11.1 \times 10^{4}$ \\
\hline LmCPB $^{\mathrm{b}}$ & $6.7 \pm 0.9$ & $81 \pm 8.5$ & $2.1 \pm 0.22$ & $31.3 \times 10^{4}$ \\
\hline$h$ CatL $^{\mathrm{c}}$ & $3.3 \pm 0.2$ & $11 \pm 0.8$ & $0.3 \pm 0.02$ & $9.1 \times 10^{4}$ \\
\hline$h$ CatS $^{\mathrm{d}}$ & $37 \pm 0.5$ & $4.6 \pm 1.5$ & $0.1 \pm 0.04$ & $0.3 \times 10^{4}$ \\
\hline$h$ CatK $^{\mathrm{d}}$ & $1.7 \pm 0.07$ & $2.2 \pm 0.7$ & $0.06 \pm 0.01$ & $3.5 \times 10^{4}$ \\
\hline
\end{tabular}

${ }^{a}$ https://www.brenda-enzymes.org/

${ }^{\mathrm{b}}$ Results obtained through the average of four measurement

${ }^{\mathrm{c}}$ Results obtained through the average of three measurement

${ }^{\mathrm{d}}$ Results obtained through the average of two measurement 
From the $K_{\mathrm{M}}$ and $\mathrm{V}_{\max }$, it is possible to calculate the $k_{\text {cat }}$ and the $k_{\text {cat }} / K_{\mathrm{M}}$ ratio. The less efficient enzyme in the assay conditions is $h$ CatS. This enzyme has a high $K_{\mathrm{M}}$ value, which indicates a lower affinity for the substrate. The turnover number $\left(k_{\mathrm{cat}}\right)$ and the ratio $k_{\mathrm{cat}} / K_{\mathrm{M}}$ for $h$ CatS were the lowest among the enzymes, indicating the low efficiency in hydrolyzing the substrate. Indeed, $h \mathrm{CatS}$ has a preference for branched hydrophobic residues in the S2 subsite (CHOE et al., 2006). As for the other CPs, $k_{\text {cat }}$ and $k_{\text {cat }} / K_{\mathrm{M}}$ exhibit satisfying results with high conversion rates of the substrates.

Having obtained the $K_{\mathrm{M}}$ values for the five enzymes, the inhibition assays were performed with a wide range of covalent reversible inhibitors. In the inhibition assays, the compounds were incubated with the enzyme in which the substrate solution is subsequently added. The substrate will try to displace the inhibitor from the active site of the enzyme by a displacement mechanism. As soon as the inhibitor is displaced, the substrate will be hydrolyzed by the enzyme, and the fluorescence signal will be observed. The higher the inhibitor affinity for the enzyme, the lower the observed fluorescence signal. The fluorescence signal has units of velocity $\left(\mathrm{RFU} \mathrm{s}{ }^{-1}\right)$ and was plotted against different inhibitors concentrations $\left(\mathrm{mol} \mathrm{L}^{-1}\right)$ as shown in Figure 14 for the compound Neq0570. The inhibition constant $K_{\mathrm{i}}$ was obtained from equation 2 through a nonlinear fitting and was then converted to $\mathrm{p} K_{\mathrm{i}}\left(-\log _{10}=K_{\mathrm{i}}\right)$. The higher the $\mathrm{p} K_{\mathrm{i}}$, the greater the affinity of the compound for the target.

Figure 14: Inhibition curve obtained for the prototypic compound Neq0570 against Cruzain in the presence of the substrate Z-Phe-Arg-AMC.

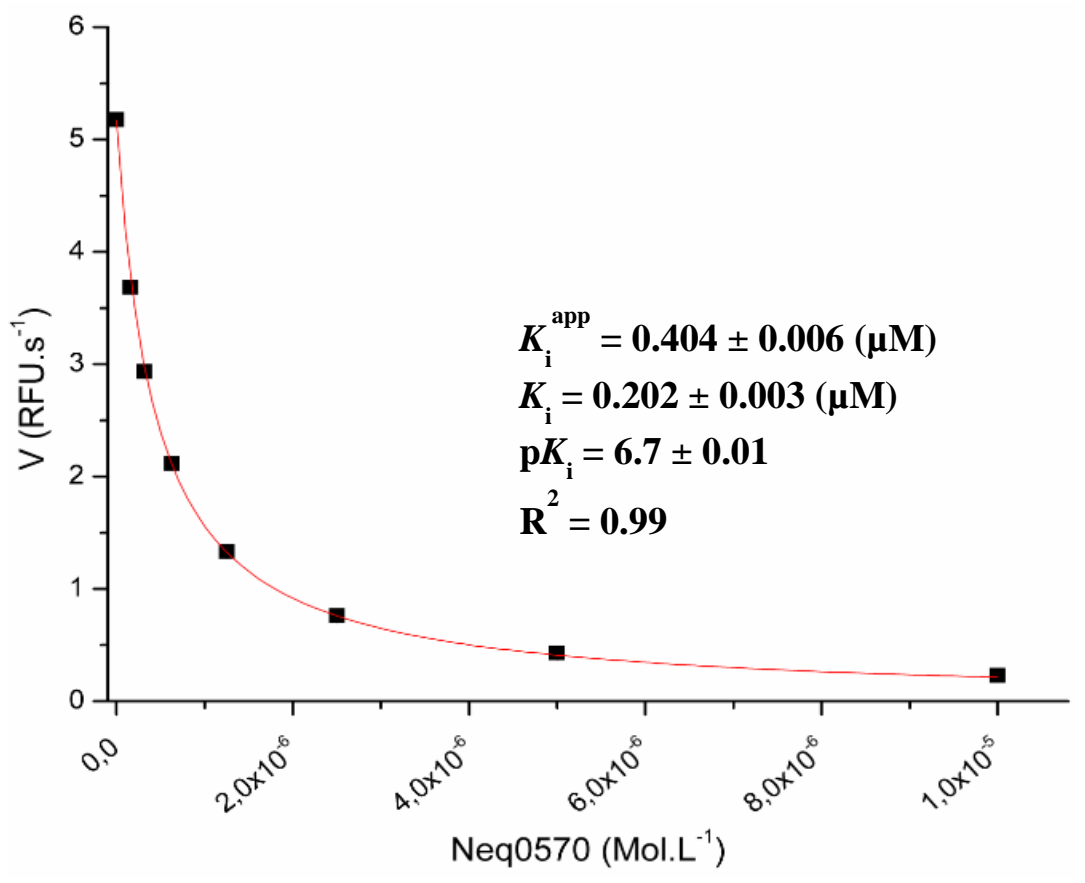


Twenty-two compounds were selected for the inhibition assays with the five CP in which their $\mathrm{p} K_{\mathrm{i}}$ values and structures are presented in Table 2. Compounds bearing a pyrazole group in the $\mathrm{P} 3$ position were chosen to evaluate the influence of this group in the bimolecular recognition process. The trifluoro ethylamine group in $\mathrm{P} 3 / \mathrm{P} 2$ was also chosen, as they are derivatives of Odanacatib and BaCz007. Compounds with a sulfonamide in P3 were selected to evaluate if this class of compounds is an acceptable bioisostere to replace the amide bond in $\mathrm{P} 3 / \mathrm{P} 2$. Lastly, pairs of compounds with different structural groups in P1 were selected to map the $\mathrm{S} 1$ and $\mathrm{S} 1$ ' subsites, since little is known about these interactions.

In addition to the 22 compounds selected, a total of 130 compounds were tested against $\mathrm{Cz}, 110$ against $L m \mathrm{CPB}$ and 82 against $h$ Cat-L. These inhibition studies were perform in collaboration with other members of the NEQUIMED/IQSC/USP group.

\subsection{MMP/SAR analysis of a series of dipeptidyl nitriles}

The chosen compounds are dipeptidyl nitrile that acts as reversible covalent inhibitors and displays a competitive mechanism of inhibition (AVELAR et al., 2015).

Table 2: Inhibitors chosen for the SAR and bio calorimetric studies with the $\mathrm{p} K_{\mathrm{i}}$ values for the five CPs, as well as their molecular structures. Protozoa CPs are black colored and mammalian blue-colored.

\begin{tabular}{|c|c|c|c|c|c|}
\hline Structure & $\mathbf{p} K_{\mathrm{i}}(\mathrm{Cz})$ & $\begin{array}{c}\mathbf{p} K_{\mathrm{i}} \\
(\operatorname{LmCPB})\end{array}$ & $\begin{array}{c}\mathbf{p} \boldsymbol{K}_{\mathbf{i}} \\
(h \text { CatL) }\end{array}$ & $\begin{array}{c}\mathbf{p} K_{\mathbf{i}} \\
(h \text { CatK) }\end{array}$ & $\begin{array}{c}\mathbf{p} K_{\mathrm{i}} \\
(h \mathrm{CatS})\end{array}$ \\
\hline Neq0533.1 & $7.3 \pm 0.01$ & $7.1 \pm 0.01$ & $8.2 \pm 0.01^{\mathrm{a}}$ & $6.5 \pm 0.03^{a}$ & $6.8 \pm 0.07^{a}$ \\
\hline Neq0569.2 & $7.8 \pm 0.01$ & $7.3 \pm 0.04$ & $7.6 \pm 0.01^{\mathrm{a}}$ & $8.3 \pm 0.2^{a}$ & $7.4 \pm 0.03^{a}$ \\
\hline Neq0570 & $6.7 \pm 0.01$ & $6.6 \pm 0.01$ & $7.4 \pm \mathbf{0 . 0 3}$ & $6.4 \pm 0.02$ & $7.3 \pm 0.01$ \\
\hline
\end{tabular}




\begin{tabular}{|c|c|c|c|c|c|}
\hline $\begin{array}{r}\text { Neq0635.1 } \\
F\end{array}$ & $7.3 \pm 0.02$ & $6.9 \pm 0.02$ & $7.4 \pm 0.05$ & $6.4 \pm 0.02$ & $7.6 \pm 0.02$ \\
\hline Neq0641 & $7.3 \pm 0.01$ & $7.3 \pm 0.03$ & $6.6 \pm 0.03$ & $7.1 \pm 0.01$ & $7.2 \pm 0.05$ \\
\hline Neq0642 & $8.1 \pm 0.01$ & $7.7 \pm 0.05$ & $6.1 \pm 0.03$ & $7.9 \pm 0.03$ & $6.9 \pm 0.03$ \\
\hline Neq0643.1 & $8.7 \pm 0.03$ & $8.6 \pm 0.02$ & $8.8 \pm 0.03$ & $8.6 \pm 0.01$ & $8.7 \pm 0.06$ \\
\hline Neq0818 & $7.3 \pm 0.01$ & $6.8 \pm 0.05$ & $7.7 \pm \mathbf{0 . 0 2}$ & $7.2 \pm 0.04$ & $8.0 \pm 0.03$ \\
\hline Neq0819 & $7.4 \pm 0.03$ & $7.1 \pm 0.02$ & $7.4 \pm 0.05$ & $7.1 \pm 0.02$ & $7.4 \pm 0.03$ \\
\hline Neq0831 & $7.0 \pm 0.07$ & $7.0 \pm 0.06$ & $6.4 \pm 0.02$ & $6.8 \pm 0.03$ & $7.4 \pm 0.03$ \\
\hline
\end{tabular}




\begin{tabular}{|c|c|c|c|c|c|}
\hline Neq0838 & $6.8 \pm 0.02$ & $6.8 \pm 0.02$ & $6.5 \pm 0.01$ & $6.6 \pm 0.07$ & $7.0 \pm 0.02$ \\
\hline Neq0865 & $6.9 \pm 0.01$ & $6.2 \pm 0.02$ & $7.3 \pm 0.03^{a}$ & $6.2 \pm 0.07^{\mathrm{a}}$ & $7.7 \pm 0.1^{a}$ \\
\hline Neq0866 & $7.4 \pm 0.04$ & $6.7 \pm 0.01$ & $8.6 \pm 0.05^{a}$ & $6.4 \pm 0.07^{a}$ & $6.7 \pm 0.1^{\mathrm{a}}$ \\
\hline Neq0866. & $6.3 \pm 0.03$ & $6.1 \pm 0.03$ & $6.9 \pm 0.01^{a}$ & $5.6 \pm 0.04^{a}$ & $5.9 \pm 0.05^{a}$ \\
\hline Neq0877 & $7.2 \pm 0.05$ & $6.8 \pm 0.04$ & $8.1 \pm 0.04^{a}$ & $6.0 \pm 0.03^{a}$ & $6.5 \pm 0.05^{a}$ \\
\hline Neq0922 & $7.9 \pm 0.01$ & $7.7 \pm 0.01$ & $7.2 \pm 0.03^{a}$ & $7.8 \pm 0.02^{\mathrm{a}}$ & $7.3 \pm 0.01^{a}$ \\
\hline
\end{tabular}




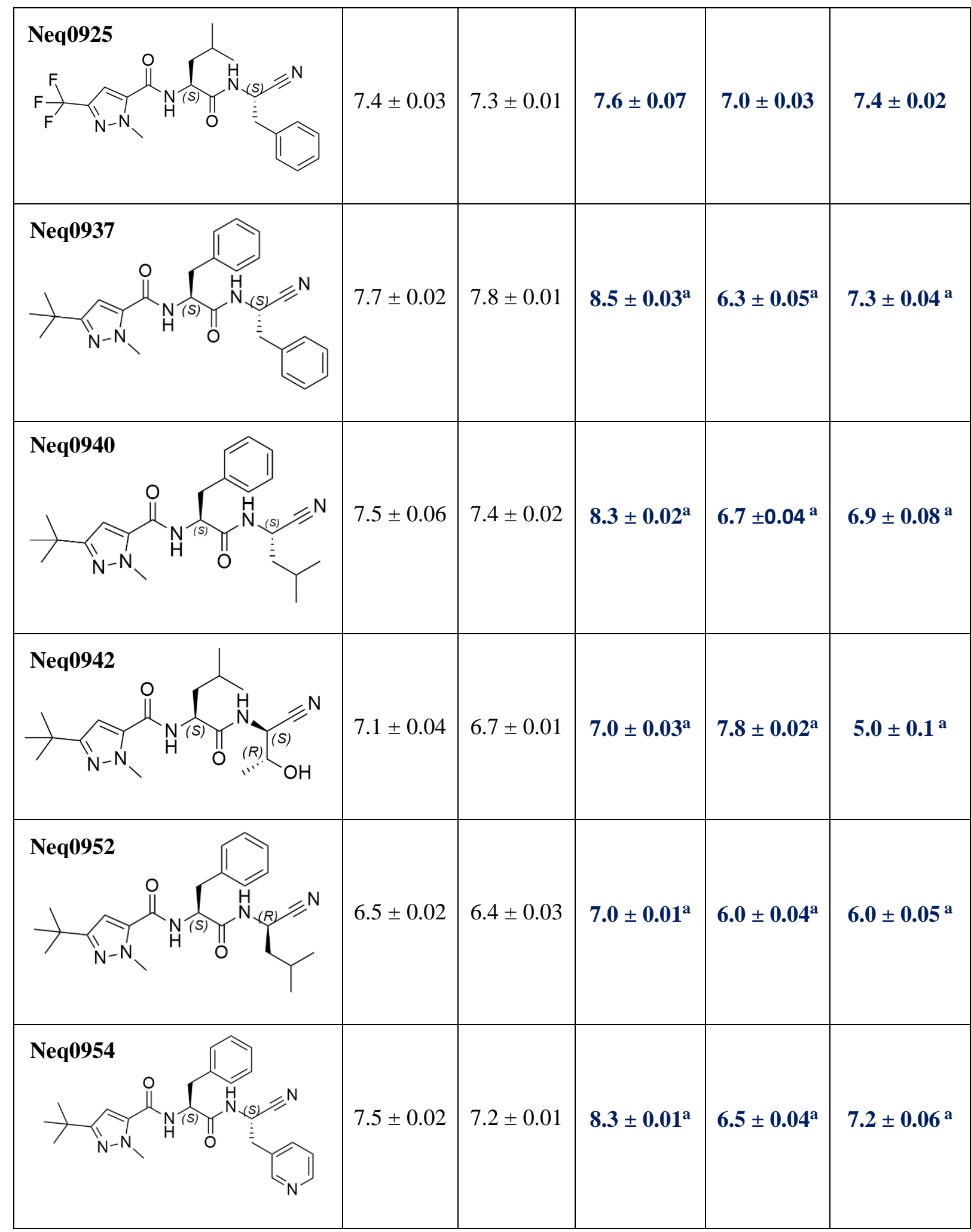

${ }^{\mathrm{a}}$ Kinetics assays performed at the University of Bonn (Germany). The same protocol was used for the determination of the $\mathrm{p} K_{\mathrm{i}} \mathrm{s}$.

The MMP/SAR analysis considered the differences in affinity related to a structural change, defined as $\Delta \mathrm{p} K_{\mathrm{i}}$. The $\Delta \mathrm{p} K_{\mathrm{i}}$ is calculated through the differences in affinity between two molecules (e.g., $\Delta \mathrm{p} K_{\mathrm{i}}=\mathrm{p} K_{\mathrm{i}}[\mathbf{N e q 0 5 6 9 . 2}]-\mathrm{p} K_{\mathrm{i}}$ [Neq0533.1]). $\Delta \mathrm{p} K_{\mathrm{i}}$ values lower than $0.2 \log$ 
units were considered not significant for affinity. For selectivity, a $\Delta \mathrm{p} K_{\mathrm{i}}$ equal or higher than $1.0 \log$ units was considered significant. Therefore, 8 compounds with different substituents at the P1, P2, and P3 positions and different stereochemistry were evaluated in Figure 15.

Figure 15: MMPA of Neq0533.1 with seven compounds with $\Delta \mathrm{p} K_{\mathrm{i}}$ values corresponding to structural modifications targeting five enzymes. Positive modifications are shown in green, negative in red, and when no significant difference was observed in grey. Modifications in P1 are highlighted as orange, P2 blue and P3 red.

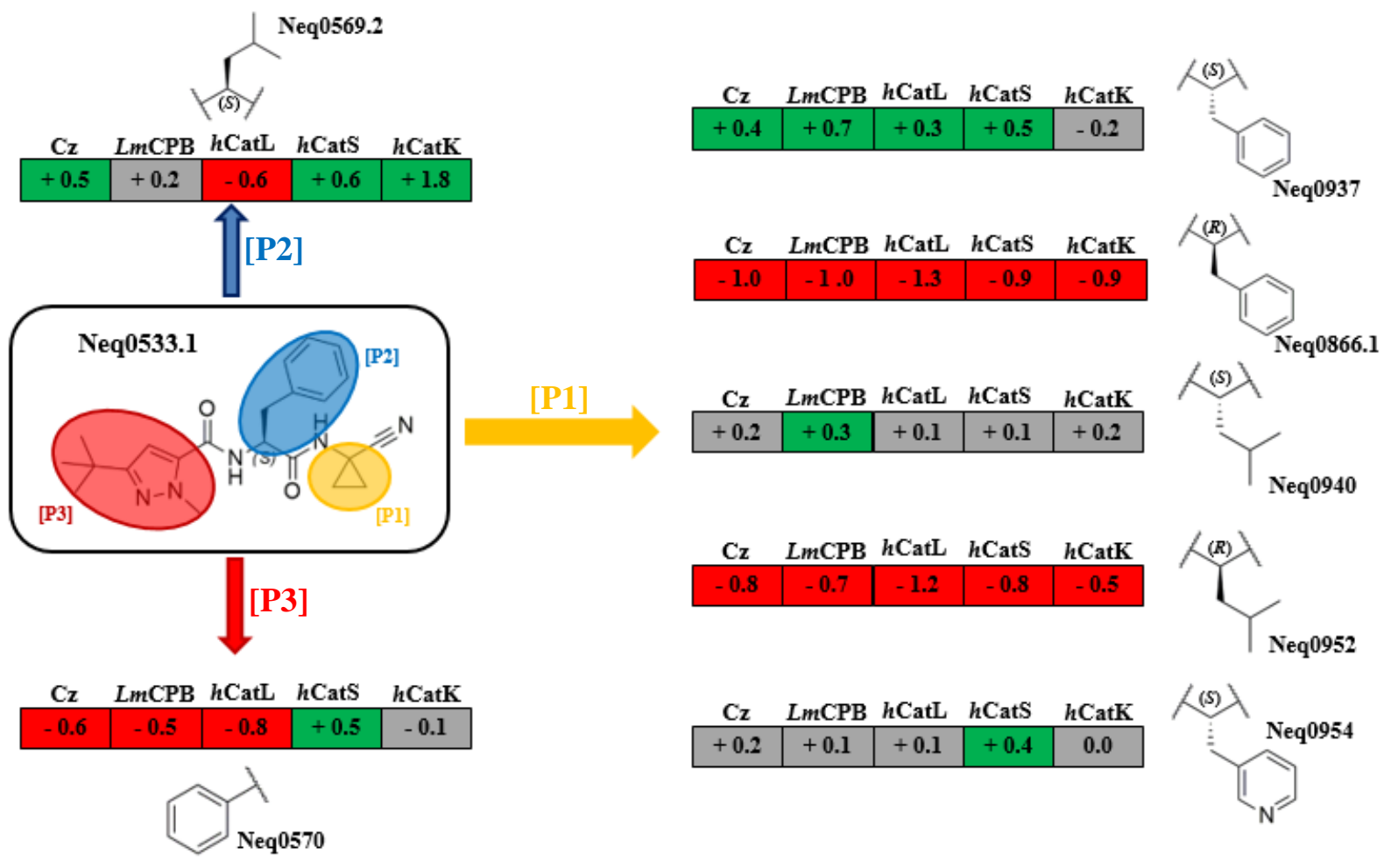

The structural modification at the $\mathrm{P} 3$ position changing the 3-(tert-butyl)-1-methyl-1 Hpyrazole (Neq0533.1) for the phenyl group (Neq0570) led to a loss in affinity for almost all the CPs, except for $h$ CatS. Changing the 3-(tert-butyl)-1-methyl-1H-pyrazole for the phenyl brought a significant decrease for $h$ CatL affinity due to the methyl in the 3-(tert-butyl)-1methyl-1H-pyrazole group, which is able to perform van der Waals interactions with the Leu69 residue in the $\mathrm{S} 3$ pocket of $h \mathrm{CatL}$ (ASAAD et al., 2009). As for $h$ CatS, the Phe70 residue in the S3 pocket can possibly perform $\pi-\pi$ stacking interactions with the phenyl ring of the inhibitor without having enough space to accommodate the bulkier 3-tert-butyl-N-methylpyrazole group (JADHAV et al., 2014).

Modification in P2 changing a Phe (Neq0533.1) for a Leu (Neq0569.2) led to a gain in the affinity for four of the CPs, with the highest change observed for $h$ CatK $(+1.8 \log$ units). 
$h$ CatL was affected as expected due to the preference of this enzyme for aromatic residues in the $\mathrm{P} 2$ position.

Structural modifications in P1 take into account five compounds. Not surprisingly, the $(S)$ configuration of the moiety in P1 was favored rather than the $(R)$ configuration, as also observed in a recent study for amino acids in P2 (AVELAR et al., 2015). The substitution of the cyclopropane to the $(S)$-benzyl (Neq0937) raised the affinity for all CPs. However, when the $(R)$ configuration (Neq0866.1) was analyzed, a considerable loss in affinity occurred. The exchange of the cyclopropane for the iso-propyl (Neq0940) did not lead to any particular improvement.

The modification from the cyclopropane to the pyridine group (Neq0954), maintains the affinity for all the CPs. Despite no significant change, pyridine is a fascinating group in the medicinal chemistry field. The pyridine raises the solubility of the inhibitor without modifying the main hydrophobic interaction with the target protein.

Other structural modifications at the P1 position were investigated among pairs of compounds, as shown in Figure 16. 
Figure 16: MMPA with $\Delta \mathrm{p} K_{\mathrm{i}}$ values corresponding to structural modifications in the P1 position targeting five enzymes. Positive modifications are shown in green, negative in red, and when no significant difference was observed in grey. Modifications in P1 are marked as orange.
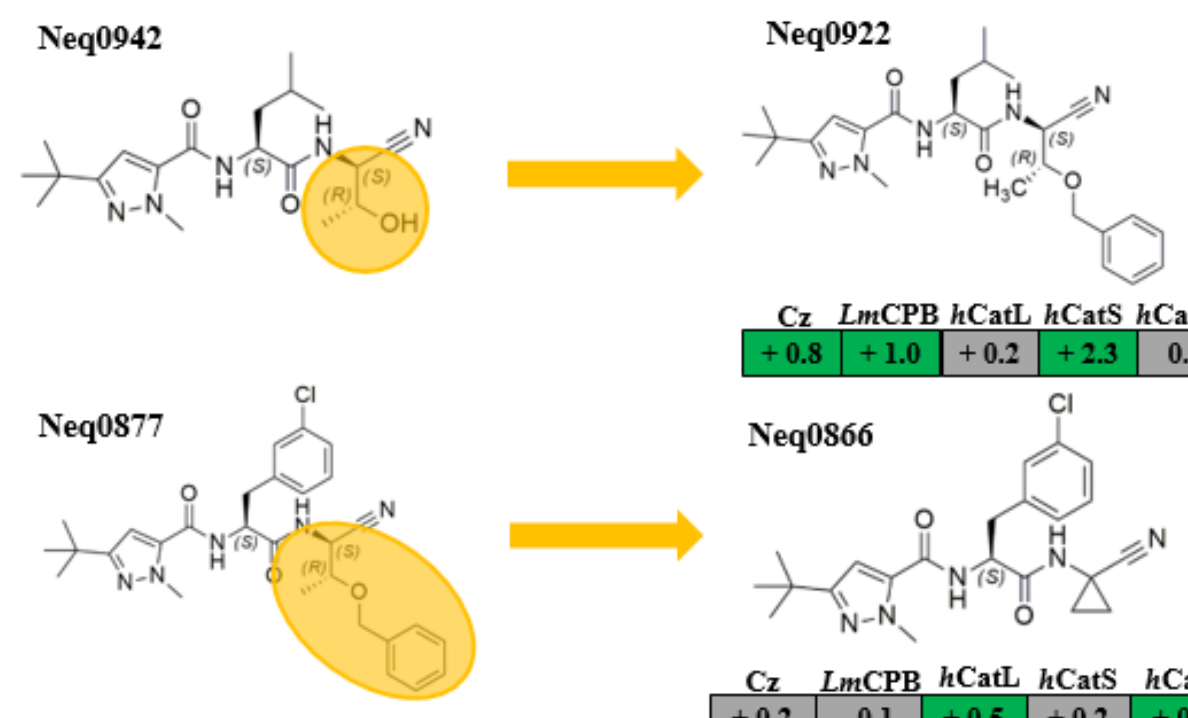

$\mathrm{Cz} L m \mathrm{CPB} h \mathrm{CatL}$ CatS $h \mathrm{CatK}$

\begin{tabular}{|l|l|l|l|l|}
+0.8 & +1.0 & +0.2 & +2.3 & 0.0 \\
\hline
\end{tabular}
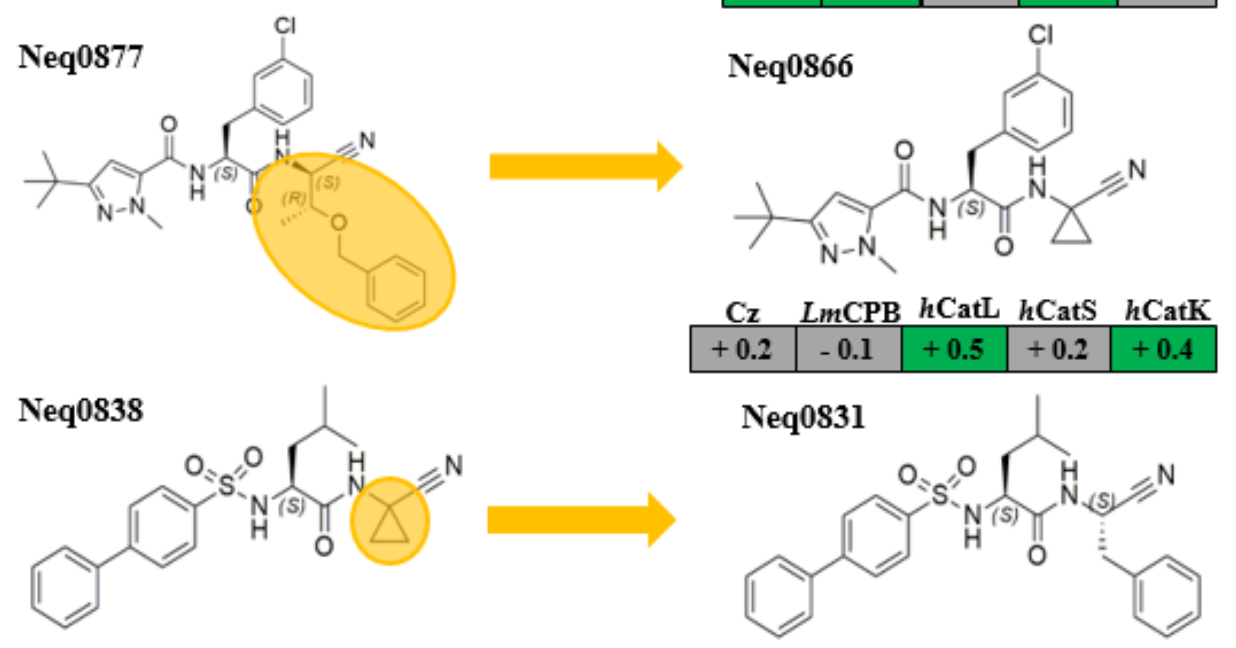

Cz $L m \mathrm{CPB} h \mathrm{CatL} h \mathrm{CatS} \quad h \mathrm{CatK}$

\begin{tabular}{l|l|l|l|l|}
+0.2 & +0.2 & -0.1 & +0.4 & +0.2 \\
\hline
\end{tabular}

Neq0635.1

Neq0643<smiles>CC(C)C[C@H](NC(=O)NC1CC2CCC1C2N)C(F)(F)F</smiles>

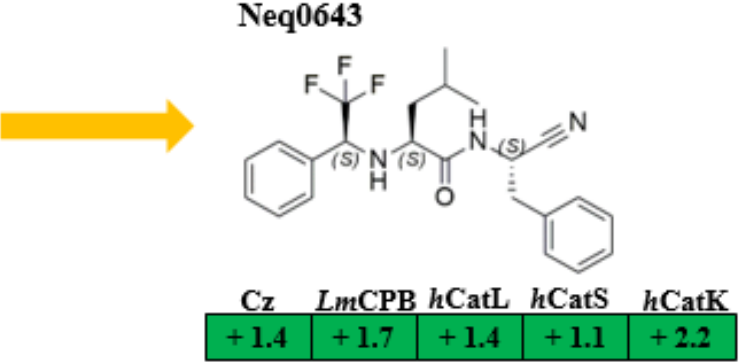

The modification in P1 for Neq0942 to Neq0922 brought significant changes in affinity for $\mathrm{Cz}, L m \mathrm{CPB}$, and $h \mathrm{CatS}$, especially for $h \mathrm{CatS}$, for the latter we observed an activity cliff with an improvement in affinity over one hundredfold. $h \mathrm{CatS}, \mathrm{Cz}$, and $L m \mathrm{CPB}$ may not tolerate hydrogen bond donors as the hydroxyl group in the threonine, while showing a preference for hydrogen bond acceptors and large hydrophobic moiety as the protected benzyl threonine (Thr$\mathrm{O}-\mathrm{Bn}$ ) in Neq0922. It is important to point out that the Thr-O-Bn moiety is interacting with the $\mathrm{S} 1$ ' subsite of the CPs and not the $\mathrm{S} 1$. The Thr-O-Bn is a large and flexible group and thus have a different mode of interaction leading to the $\mathrm{S} 1$ ' pocket. 
For Neq0877 and Neq0866, no significant change in affinity occurred for the five CPs when the Thr-O-Bn was changed to the smallest cyclopropane moiety. Probably the loss of S1'P1 interaction is counterbalanced with the higher electrophilic character of the carbon on the nitrile due to its interactions with the cyclopropane. In a medicinal chemist point of view, the cyclopropane group contains other important features as metabolic stability, small size, and absence of stereogenic centers (TALELE, 2016).

The effects described above were detected as well for the sulfonamides Neq0838 and Neq0831, in which the substitution of the cyclopropane group to a benzyl group led to no meaningful differences in affinity.

The greatest improvement in affinity was observed when the non-peptidic pairs Neq0635.1 and Neq0643.1 were analyzed. The modification of a cyclopropane to a benzyl group led to over one log unit increase in affinity. An activity cliff was observed for $h$ CatK, with over one hundredfold of gain in the compounds' affinity. For this reason, the inhibitors will be further analyzed for their chemical properties through a SAR cycle (Figure 20).

Some modifications in the P2 and P3 positions were also analyzed between pairs, as depicted in Figure 17. 
Figure 17: MMPA with $\Delta \mathrm{p} K_{\mathrm{i}}$ values corresponding to structural modifications in $\mathrm{P} 2$ and $\mathrm{P} 3$ targeting five enzymes. Positive modifications are shown in green, negative in red, and when no significant difference was observed in grey. Modifications in P2 are marked as blue and P3 as red.

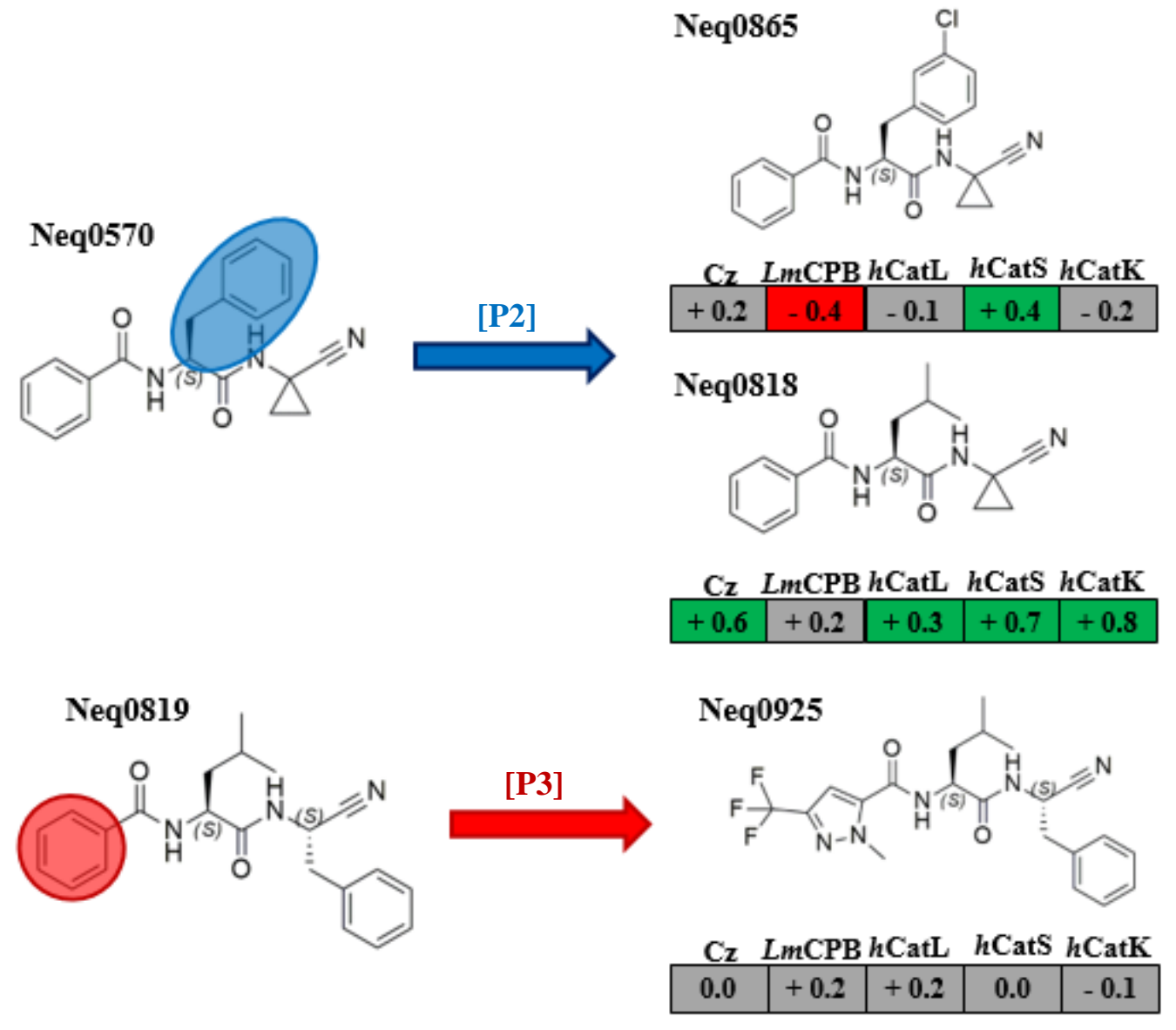

The transformation at P2 changing the phenyl ring for the 3-chlorophenyl leads to no significant improvement. When changing the $(S)$-Phe for the $(S)$-Leu group a slight increase in affinity occurred for all the five CPs. $h$ CatK was the enzyme in which the modification affects more positively due to the preference for a small group in that position.

When taking into account the P3 modifications, the use of the 1-methyl-3(trifluoromethyl)-1H-pyrazole group (Neq0925) has brought no significant effect in affinity. This implies that the substitution of the tert-butyl for the $\mathrm{CF}_{3}$ in the 1-methyl-1H-pyrazole structure influenced negatively the affinity. It was possible to assume that the trifluoromethyl moiety, due to its high polarity, forced the orientation of the pyrazole in the $\mathrm{P} 3$ pocket blocking hydrophobic interactions with the Leu69. It is important to point out that in all cases when the 3-(tert-butyl)-1-methyl-1H-pyrazole was used a gain in the inhibitors' affinity was observed.

Stereochemistry differences in pairs, for the $\mathrm{P} 1$ and $\mathrm{P} 3$ position were evaluated as shown in Figure 18. 
Figure 18: Analysis of different stereochemistry in MMP with $\Delta \mathrm{p} K_{\mathrm{i}}$ values corresponding to structural modifications targeting five enzymes. Positive modifications are shown in green, negative in red. Modifications in $\mathrm{P} 1$ are marked as orange and $\mathrm{P} 2 / \mathrm{P} 3$ as blue.
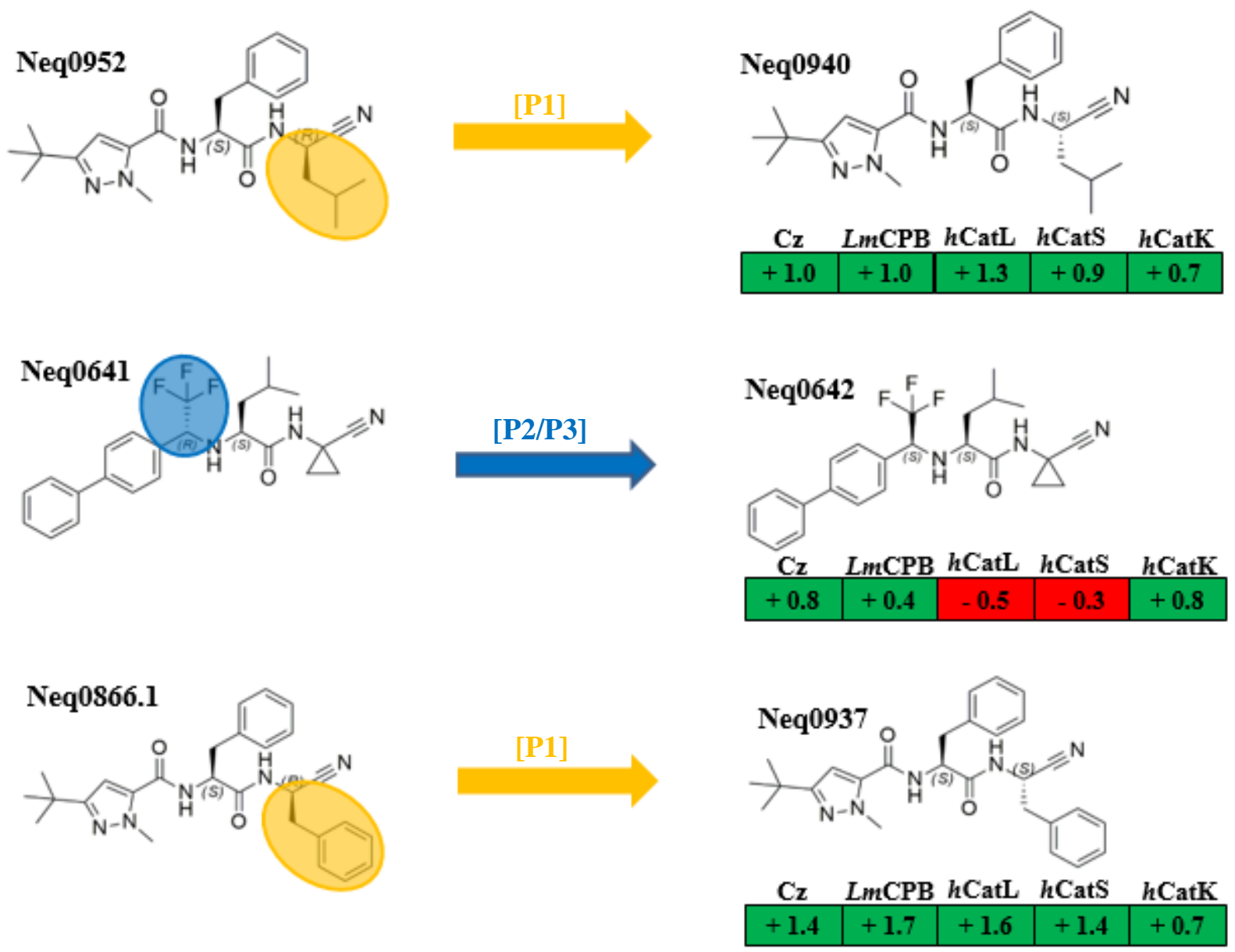

As discussed earlier, the transformations at P1 lead to a gain of almost 1.0 logarithmic unit or more, for the 5 enzymes, thereby showing a strong preference for the $\mathrm{S}$ configuration. When analyzing the $\mathrm{P} 2 / \mathrm{P} 3$ position, specifically for the trifluoro ethylamine group configuration, the enzymes did not suffer significant changes in affinity regard of the inversion of configuration. These results give the opportunity to use both configurations without greater loss in affinity for CPs. The $\mathrm{CF}_{3}$ group is an interesting group in medicinal chemistry because it can mimic the $\mathrm{C}=\mathrm{O}$ of the peptide bond and bring metabolic stability to the molecule. The $\mathrm{sp}_{3}$ hybridization of the atoms in the $\mathrm{CF}_{3}$ group allows better orientation of the molecule in the enzyme's active site, improving interactions with the target and thus improving affinity (SANI; VOLONTERIO; ZANDA, 2007).

A double transformation cycle was made aiming to identify structural changes that leads to a gain in the compound's affinity by analyzing the additivity in the SAR (Figure 19). Additivity can be evaluated when comparing a $\Delta \mathrm{p} K_{\mathrm{i}}$ value related to double structural 
transformations of a pair with the sum of the $\Delta \mathrm{p} K_{\mathrm{i}}$ values resulted from the pairs of individual transformations. The additivity analysis considers all the processes that occur when a structural modification is made in a molecule, such as changes in the types of molecular interactions and their physicochemical characteristics.

The effects of the structural transformations can be additive, superadditive or subadditive. A superadditive effect occurs when the $\Delta \mathrm{p} K_{\mathrm{i}}$ related to more than one structural transformation is higher than the sum of the pairs $\Delta \mathrm{p} K_{\mathrm{i}}$. A subadditive effect occurs when the sum of the affinities of individual structural transformations are greater than the affinity of the two structural transformations. The additive effect occurs when the individual structural transformations are equal to the affinity observed for the two structural transformations.

Figure 19: Nonadditivity in SAR analysis of four compounds where the $\Delta \mathrm{p} K_{\mathrm{i}}$ values shown are related to $h C a t K$ inhibition. The green arrow represents positive changes in affinity and the grey arrow no significant change. Blue circles indicate a structural modification in P2 and brown circle in P3.

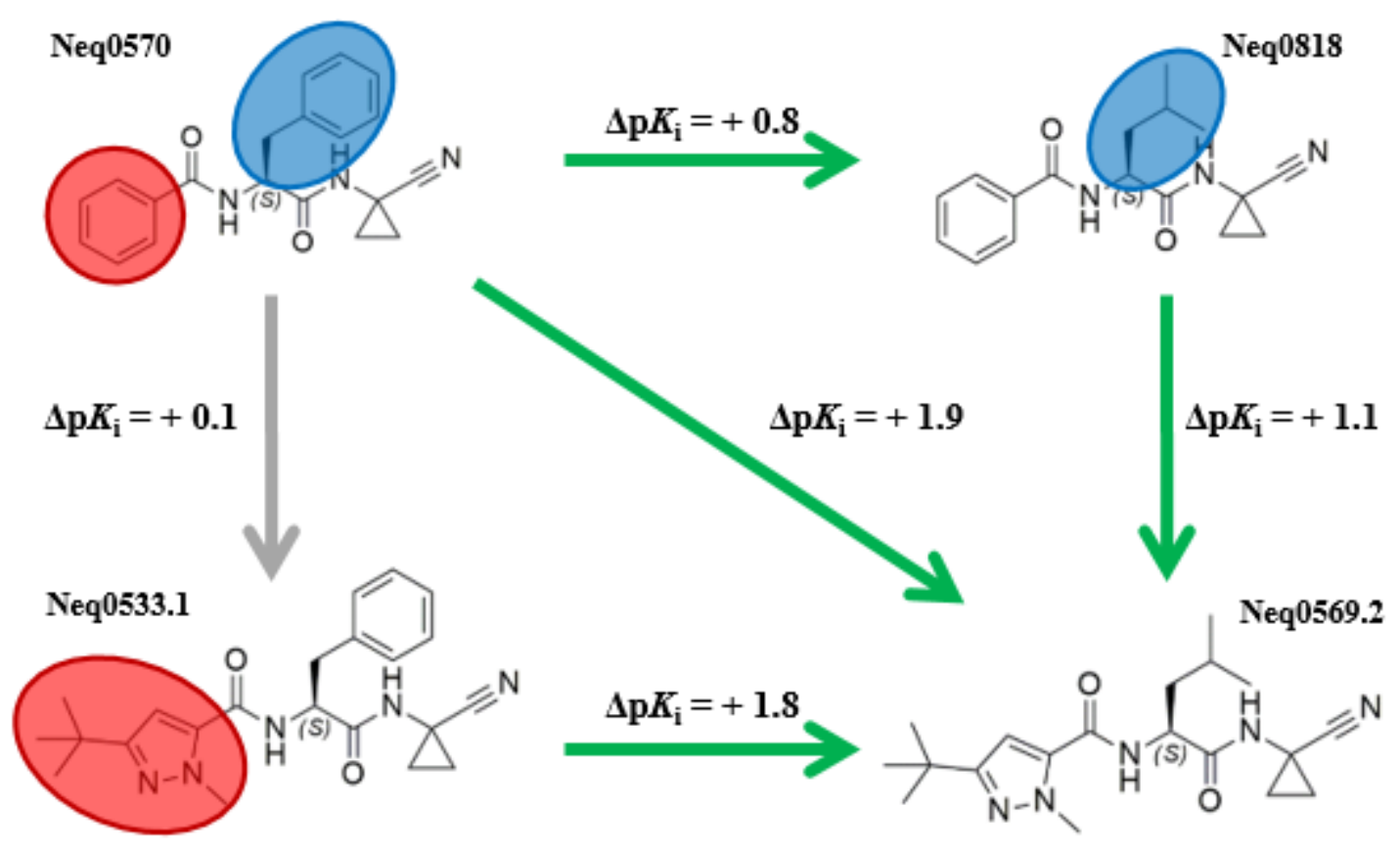

Table 3 shows the $\Delta \mathrm{p} K_{\mathrm{i}}$ for the five CPs related to the figure 19 cycle.

Table 3: $\Delta \mathrm{p} K_{\mathrm{i}}$ for the four CPs from the SAR analysis of Figure 19, the notation $[\mathrm{X} \rightarrow \mathrm{Y}]$ indicates a structural modification. Diagonal transformation is highlighted in orange

\begin{tabular}{|c|c|c|c|c|c|}
\hline Structural transformation & $\mathbf{C z}$ & $\boldsymbol{L m C P B}$ & $\boldsymbol{h C a t L}$ & $\boldsymbol{h C a t K}$ & $\boldsymbol{h C a t S}$ \\
\hline$[\mathbf{N e q 0 5 7 0} \rightarrow \mathbf{N e q 0 8 1 8}]$ & +0.6 & +0.2 & +0.3 & +0.8 & +0.7 \\
\hline$[\mathbf{N e q 0 5 7 0} \rightarrow$ Neq0533.1] & +0.6 & +0.5 & +0.8 & +0.1 & -0.5 \\
\hline$[\mathbf{N e q 0 5 3 3 . 1} \rightarrow \mathbf{N e q 0 5 6 9 . 2}]$ & +0.5 & +0.2 & -0.6 & +1.8 & +0.6 \\
\hline$[$ Neq0818 $\rightarrow$ Neq0569.2] & +0.5 & +0.5 & -0.1 & +1.1 & -0.6 \\
\hline
\end{tabular}




$[\mathrm{Neq0570} \rightarrow$ Neq0569.2 $]+1.1 \quad+0.7 \quad+0.2 \quad+1.9+0.1$

Strong superadditivity was observed for $h$ CatK in which the sum of the $\Delta \mathrm{p} K_{\mathrm{i}}$ of the transformations [Neq0570 $\rightarrow$ Neq0818] and [Neq0570 $\rightarrow$ Neq0533.1] was equal to +0.9 and the double structural modification to a $\Delta \mathrm{p} K_{\mathrm{i}}$ of +1.9 . The obtained results demonstrated the greater influence that substituents at the P2 position have for $h \mathrm{CatK}$. The structural transformations between $[\mathrm{Neq0570} \rightarrow \mathrm{Neq0818}]$ and [Neq0533.1 $\rightarrow$ Neq0569.2] displayed the largest gain in affinity. This gain is related to the structural change of a Phe for the Leu group in $\mathrm{P} 2$ which fits better in the S2 pocket of the enzyme. In addition, the structural changes in the $\mathrm{P} 3$ position demonstrate that the 3-(tert-butyl)-1-methyl- $1 H$-pyrazole has a positive effect in affinity for $h \mathrm{CatK}$ when combined with the Leu in P2. The 3-(tert-butyl)-1-methyl-1Hpyrazole can increase the number of interactions between the inhibitor and the target. The S3 pocket of $h$ CatK has a Tyr67 and an Asn61 residue which can form H-bond interactions with the nitrogen atom on the pyrazole ring.

$\mathrm{Cz} \Delta \mathrm{p} K_{\mathrm{i}}$ values for the individual structural transformations [Neq0570 $\left.\rightarrow \mathbf{N e q 0 8 1 8}\right]=$ +0.6 and $[$ Neq0570 $\rightarrow$ Neq0533.1] $=+0.6$ shown in Figure 19 sum up +1.2 . The double structural transformations that correspond to [Neq0570 $\rightarrow$ Neq0569.2] has a $\Delta \mathrm{p} K_{\mathrm{i}}$ of +1.1 . As a difference in $\Delta \mathrm{p} K_{\mathrm{i}}$ of \pm 0.2 is considered not meaningful, the results showed that the structural transformations on $\mathrm{Cz}$ have an additive effect. The same effect was observed for $L m C P B$ since both $\Delta \mathrm{p} K_{\mathrm{i}}$ were equal to +0.7 .

$h$ CatL and $h$ CatS displayed effects of subadditivity for the structural transformations reported in Figure 19.

Alongside with the cycle shown in Figure 19, another double transformation cycle was made using some of the compounds in Table 2 (Figure 20). We seek to evaluate if there are additivity effects in the structural transformations between the pairs that lead to Neq0643.1. 
Figure 20: Nonadditivity in SAR analysis of six compounds where the $\Delta \mathrm{p} K_{\mathrm{i}}$ values shown are related to cruzain inhibition. The green arrow represents positive changes in affinity, red arrows a negative change in affinity and grey arrow no change in affinity. Orange circles indicate a structural modification in P1, blue circles modifications in $\mathrm{P} 2$ and brown circle in P3.

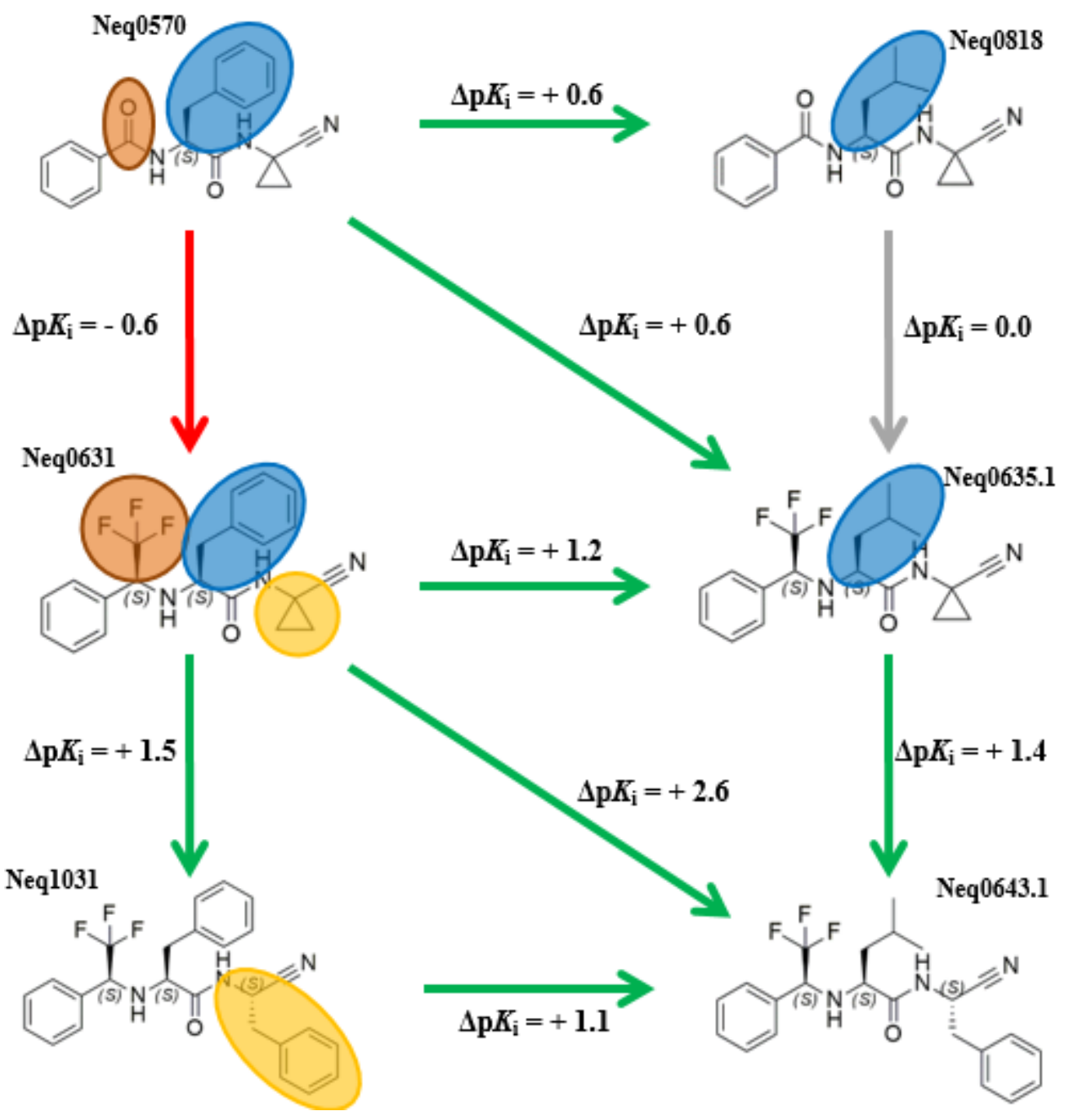

In the Table below, the $\Delta \mathrm{p} K_{\mathrm{i}}$ for $L m \mathrm{CPB}, h \mathrm{CatL}, h \mathrm{CatS}$, and $h$ CatK of Figure 20 are presented.

Table 4: $\Delta \mathrm{p} K_{\mathrm{i}}$ for the four CPs from the SAR analysis of Figure 20 , the notation $[\mathrm{X} \rightarrow \mathrm{Y}]$ indicates a structural modification. Diagonal transformations are highlighted in orange.

\begin{tabular}{|c|c|c|c|c|c|}
\hline Structural transformation & $\mathbf{C z}$ & $\boldsymbol{L m C P B}$ & $\boldsymbol{h C a t L}$ & $\boldsymbol{h C a t S}$ & $\boldsymbol{h C a t K}$ \\
\hline$[\mathbf{N e q 0 5 7 0} \rightarrow$ Neq0818] & +0.6 & +0.2 & +0.3 & +0.7 & +0.8 \\
\hline$[\mathbf{N e q 0 5 7 0} \rightarrow \mathbf{N e q 0 6 3 1}]$ & -0.6 & -0.8 & -0.6 & -0.1 & -1.0 \\
\hline$[$ Neq0570 $\rightarrow$ Neq0635.1] & +0.6 & +0.3 & 0.0 & +0.3 & 0.0 \\
\hline$[$ Neq0818 $\rightarrow$ Neq0635.1] & 0.0 & +0.1 & -0.3 & -0.4 & -0.8 \\
\hline$[$ Neq0631 $\rightarrow$ Neq0635.1] & +1.2 & +1.1 & +0.6 & +0.4 & +1.6 \\
\hline$[$ Neq0631 $\rightarrow$ Neq1031] & +1.5 & +1.9 & +1.7 & +1.0 & +1.5 \\
\hline$[$ Neq0631 $\rightarrow$ Neq0643.1] & +2.6 & +2.8 & +2.0 & +1.5 & +3.2 \\
\hline$[$ Neq0635.1 $\rightarrow$ Neq0643.1] & +1.4 & +1.7 & +1.4 & +1.1 & +2.2 \\
\hline
\end{tabular}




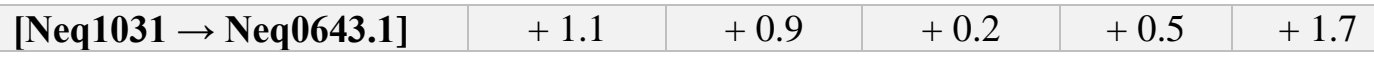

The upper part of the cycle consists of a flat SAR because there were no significant gains in affinity. At the same time, all transformations observed were superadditive. The structural transformation related to the $\Delta \mathrm{p} K_{\mathrm{i}}$ of [Neq0570 $\rightarrow$ Neq0635.1] were below $1.0 \mathrm{log}$ units. The individual transformation of [Neq0570 $\rightarrow$ Neq0631] brought a decrease in the compounds affinities for the five CPs. This loss of almost $1.0 \mathrm{log}$ unit is due to the change in the $\mathrm{P} 3$ position, changing the $\mathrm{C}=\mathrm{O}$ bond to the $\mathrm{CF}_{3}$ group. In addition, we see that the loss related to the $\mathrm{CF}_{3}$ group only occurs when the Phe and cyclopropane are at the P2 and P1 position, respectively. The structural modification of [Neq0631 $\rightarrow$ Neq0635.1] with the change of the Phe in the $\mathrm{P} 2$ position for the Leu and maintaining the $\mathrm{CF}_{3}$ group has brought an expressive increase in affinity of almost 100 times. Therefore, the combination of the $\mathrm{CF}_{3}$ group with the Leu at the $\mathrm{P} 2$ position has a positive effect on affinity.

For the lower part of the cycle, which leads to Neq0643.1 from Neq0631, the structural transformations for the five CPs were all additive as the differences in $\Delta \mathrm{p} K_{\mathrm{i}}$ were between \pm 0.1/0.2 log units, considered insignificant.

Opposed to the first cycle, a massive improvement in affinity was obtained in the second cycle. One could justify these phenomena by considering that when the $\mathrm{CF}_{3}$ is implemented, the mode of binding (MoB) of the inhibitors change, allowing a better accommodation of $\mathrm{P} 1$, $\mathrm{P} 2$ and P3 moieties in the subsites pockets. Indeed, the $\mathrm{CF}_{3}$ moiety raises the affinity of the inhibitors of about one hundredfold. Modifications at P1 and P2 displayed high gain in affinity in an additive and subadditive way. These structural modifications lead to the most potent compound of the work, Neq0643.1. Table 5 shows the physical-chemical properties for the compounds.

Table 5: Physical-chemical properties of the compounds presented in Figure 20.

\begin{tabular}{|c|c|c|c|c|}
\hline Compounds & MW $\left(\mathbf{g ~ M o l}^{-\mathbf{1}}\right)^{\mathbf{a}}$ & H-Bond Donor $^{\mathbf{a}}$ & H-Bond Acceptor $^{\mathbf{a}}$ & $\log _{\mathbf{( o / w )}} \mathbf{a}^{\mathbf{a}}$ \\
\hline Neq0570 & 319.4 & 2 & 3 & 2.2 \\
\hline Neq0631 & 387.4 & 2 & 6 & 3.6 \\
\hline Neq0818 & 299.4 & 2 & 3 & 2.0 \\
\hline Neq0635.1 & 353.4 & 2 & 6 & 3.4 \\
\hline Neq1031 & 451.5 & 2 & 6 & 4.8 \\
\hline Neq0643.1 & 417.5 & 2 & 6 & 4.5 \\
\hline
\end{tabular}

${ }^{\text {a }}$ Results obtained in the swissadme website, access in 10/07/2019.

As we can see in the Table above, the molecular weight of Neq0643.1 is bigger than Neq0570 and Neq0631. Compared with Neq0570, the number of atoms that can accept 
hydrogen bond was folded, being one of the possible reasons for the high affinity observed for the five CPs. The $\log \mathrm{P}_{(\mathrm{o} / \mathrm{w})}$ was also higher, making the molecule more lipophilic, a very desirable characteristic for bioactive compounds. Nonetheless, these properties will need to be better balanced with cell-based studies.

The five CPs have high affinity for the Neq0643.1, with $\mathrm{p} K_{\mathrm{i}}$ varying from 8.6 to 8.8. These results are very optimistic for a bioactive compound due to the high capability to inhibit all the CPs. At the same time, has brought a surplus characteristic, that is the lack of selectivity of the molecule.

\subsection{Selectivity study amid the five CPs}

Selectivity can be a very difficult task to accomplish for CPs inhibition (CIANNI et al., 2019). In this way, an analysis was conducted to evaluate the selectivity of 22 compounds (Table 2), considering their affinities for the five CPs. The results obtained for the comparison between $L m C P B \times h C a t L$ are shown in Figure 21 . The rest of the analysis is shown in the Appendix B.

Figure 21: Selectivity analysis obtained for $L m \mathrm{CPB}$ over $h$ CatL. The compounds in the blue and orange circles have differences in $\mathrm{p} K_{\mathrm{i}}$ greater or equal to $1.0 \log$ units.

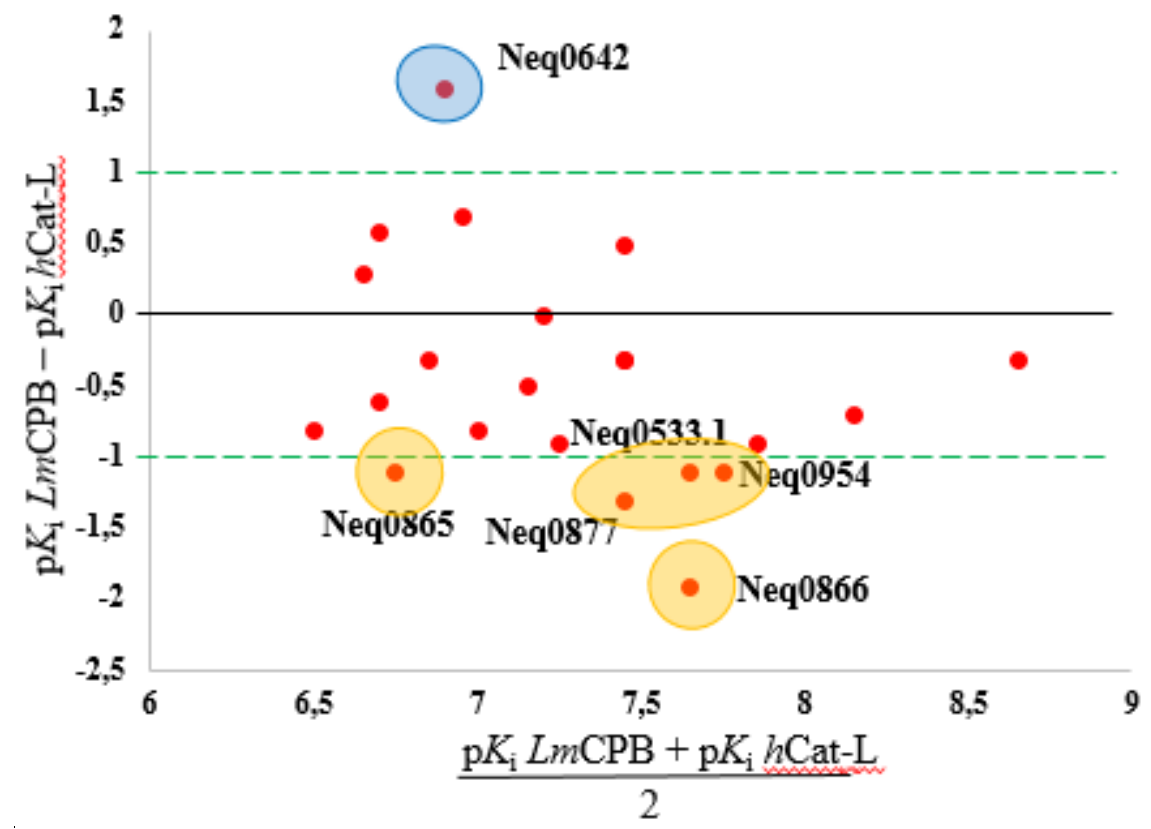

The $\mathrm{y}$-axis shows the differences between the $\mathrm{p} K_{\mathrm{i}}$ values for two enzymes and the $\mathrm{x}$ axis the average of the $\mathrm{p} K_{\mathrm{i}} \mathrm{s}$. Inhibitors for which CPs have high affinity (x-axis) are placed in 
the right part of the graph. The highest selectivity is observed for inhibitors that are farthest from zero on the y-axis.

As shown in Figure 21, the compounds are mostly distributed in the negative part of the graph. This indicates a tendency in selectivity for $h$ CatL. Above the +1.0 line, only Neq0642 exhibits a selectivity of more than $1.0 \log$ unit for $L m C P B$. As for $h$ CatL, five compounds displayed high selectivity for this enzyme with over $1.0 \log$ unit of differences in $\mathrm{p} K_{\mathrm{i}}$.

$\mathrm{Cz}$ was analyzed (Appendix B) with the cathepsins in which Neq0642 and Neq0942 displayed a difference in $\mathrm{p} K_{\mathrm{i}}$ of more than $2.0 \log$ units over $h \mathrm{CatL}$ and $h \mathrm{CatS}$ respectively. Analyzing the selectivity of $\mathrm{Cz}$ with $h \mathrm{CatK}$, Neq0866, Neq0877, Neq0937 and Neq0954, had greater selectivity for $\mathrm{Cz}$.

For $h \mathrm{CatL}$ and $h \mathrm{CatS}$, the compounds showed to be more selective for $h \mathrm{CatL}$, with 7 compounds with differences in $\mathrm{p} K_{\mathrm{i}}$ greater than $1.0 \log$ unit. As for $h \mathrm{CatL}$ and $h \mathrm{CatK}$, the differences are even greater, having ten compounds with over $1.0 \log$ units of differences in $\mathrm{p} K_{\mathrm{i}}$, in which Neq0866, Neq0877, and Neq0937 displayed more than $2.0 \log$ unit of selectivity over $h$ CatK.

Finally, the observed selectivity between $h \mathrm{CatS}$ and $h \mathrm{CatK}$ places most inhibitors close to the 0 axis. Nevertheless, most of them have more preference for $h \mathrm{CatS}$. Both enzymes had two compounds displaying selectivity beyond $1.0 \log$ unit.

In general, mammalian CPs have more affinity for the inhibitors than the protozoan CPs. Cysteine cathepsins showed high affinity for 15 of the 22 inhibitors studied. The $h$ CatL showed better affinity/selectivity for eleven inhibitors in which the most relevant were Neq0533.1, Neq0866.1, and Neq0954, which exhibit similar structures with the 3-(tert-butyl)-1-methyl$1 H$-pyrazole in $\mathrm{P} 3$ and the Phe residue at $\mathrm{P} 2$. The key modifications sit on $\mathrm{P} 1$ position, in which these inhibitors carry different moieties.

On the other hand, the most selective inhibitor among the cathepsins was Neq0942, displaying a preference for $h \mathrm{CatK}$ and $h \mathrm{CatL}$ over $h \mathrm{CatS}$ of almost $3.0 \log$ units. The most important feature in Neq0942 structure is the threonine residue at P1, bringing a crucial element to attain selectivity among the mammalian CPs. Nevertheless, Neq0642 displayed more selectivity for the protozoan CPs, with over $2.0 \mathrm{log}$ units of difference in affinity. This inhibitor has a $\mathrm{CF}_{3}$ moiety in $\mathrm{P} 3 / \mathrm{P} 2$ and a biphenyl at $\mathrm{P} 3$, thus, could be explored to achieve selectivity over mammalian CPs.

With the relationships settled, flanked by compound structures and the enzymes, a biocalorimetric study was conducted for $\mathrm{Cz}$ with the ligands Neq0533.1, Neq0569.2, Neq0570, 
Neq0635.1, Neq0643.1, Neq0818, Neq0865, Neq0866, Neq0922, Neq0925, Neq0937, Neq0940, Neq0942, and Neq0954, in which the structures are shown in the table 2.

\subsection{Differential scanning calorimetry study}

The DSC technique was used to evaluate the thermal stability of $\mathrm{Cz}$ with some of the compounds, which are identified in Table 7.

First, a reversibility study of the thermal unfolding of $\mathrm{Cz}$ was performed, seeking to identify if the process of unfolding is reversible or irreversible. Therefore, sequential scans were performed in which firstly the native protein solution was heated to $90{ }^{\circ} \mathrm{C}$, cooled and then, heated again. The result obtained is shown in Figure 22.

Figure 22: Reversibility assay performed for $\mathrm{Cz}$. The blue line corresponds to the first heating scan, ranging from 0 to $90{ }^{\circ} \mathrm{C}$, the green line corresponds to the cooling scan and the red line to the second heating process. The peak of the unfolding process is depicted with $\mathrm{Tm}=66.4^{\circ} \mathrm{C}$. The scans were done at 3 atm and with a rate of $2{ }^{\circ} \mathrm{C}$ per minute.

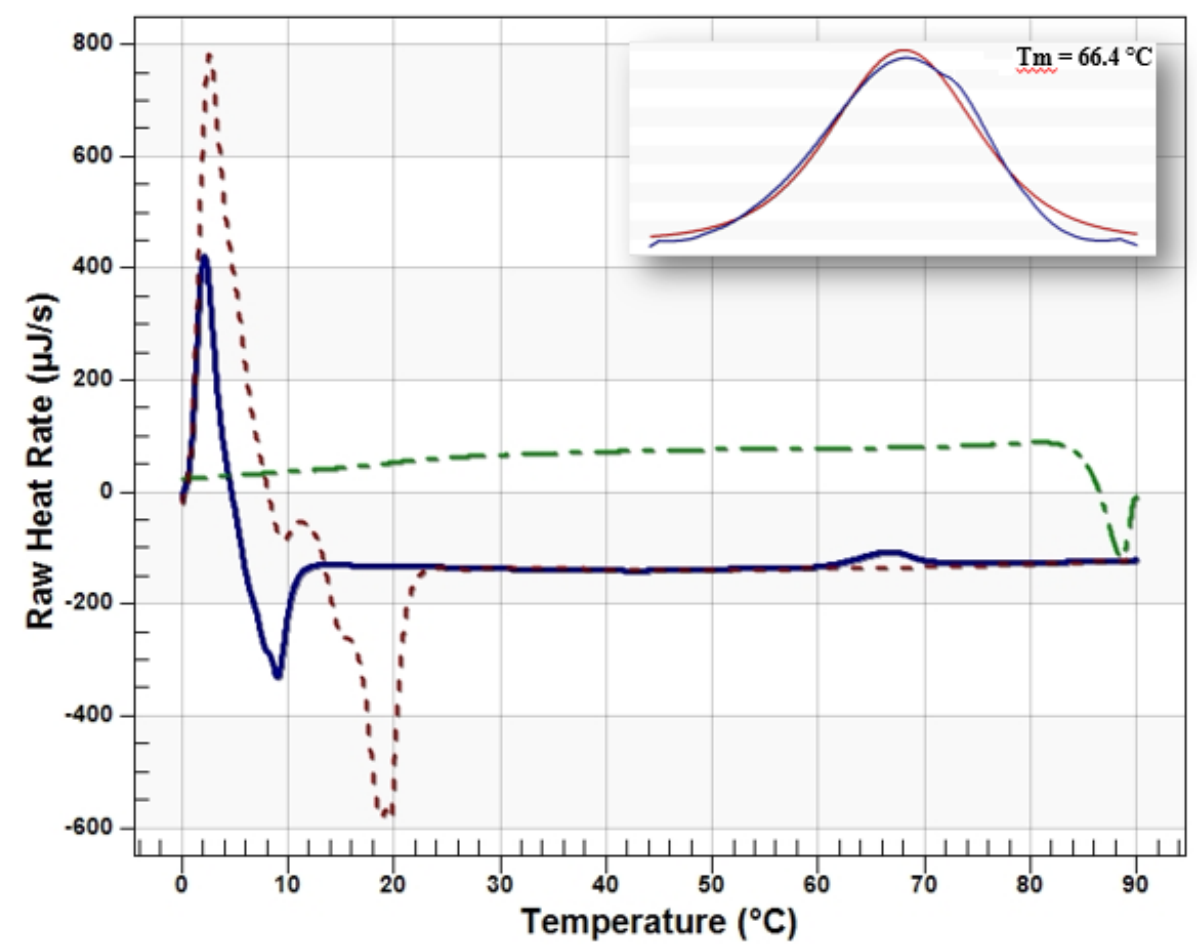

By the sequential scans, it was determined that $\mathrm{Cz}$ has an irreversible unfolding due to the non-appearance of a peak in the second heating scan. This result is in agreement with previous studies made for papain and other CPs of this family, in which an irreversible 
unfolding was also noticed (SOLÍS-MENDIOLA; ROJO-DOMÍNGUEZ; HERNÁNDEZARANA, 1993).

Having established the irreversibility unfolding of the protein, the assay of the native protein was done to determine its temperature of melting (Tm) (Figure 23).

Figure 23: (a) Raw data before the baseline subtraction where the integration of the area of the peak was performed. (b) Cruzain unfolding peak obtained after the correction of the blank (buffer-buffer), the blue line corresponds to the raw data obtained and the red line is the adjustment of the curve using a Two-State Scaled model. The solution was heated from 0 to $90{ }^{\circ} \mathrm{C}$ in acetate buffer $\mathrm{pH}=5.5,3 \mathrm{~atm}$ and a rate of $2{ }^{\circ} \mathrm{C} / \mathrm{min}$.

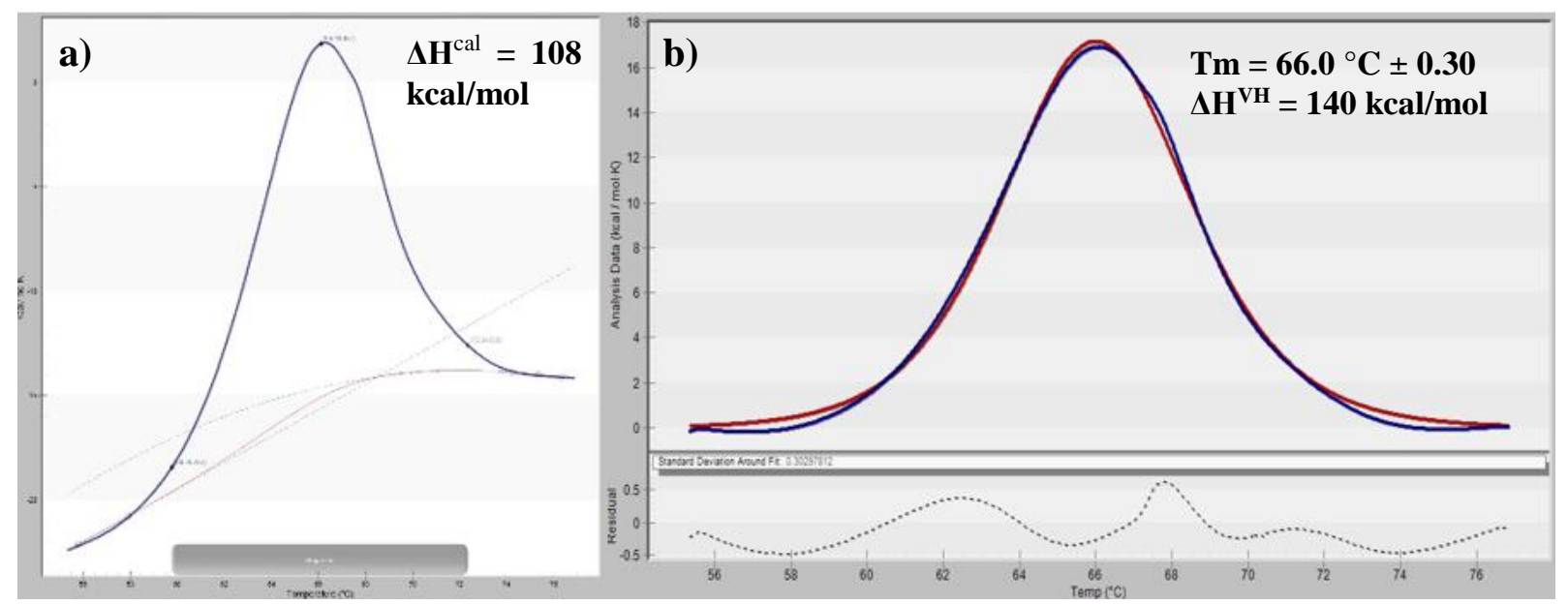

In the figure above, an endothermic peak was observed being characteristic for proteins thermal unfolding. The presence of one peak is an indicative of the protein structure cooperativity. $\mathrm{Cz}$ has a two-domain structure and because only one peak appeared in the scan, both domains unfold cooperatively. At Figure 23(a) the peak begins in a lower stage and finishes in a higher one due to the heat capacity $(\mathrm{Cp})$ change of the thermal unfolding of the protein. A positive $\Delta \mathrm{Cp}$ was observed for $\mathrm{Cz}$ with a mean value of approximately $+6.8 \mathrm{kcal}$ $\mathrm{mol}^{-1} \mathrm{~K}^{-1}$. A positive $\Delta \mathrm{Cp}$ indicates that the $\mathrm{Cp}$ of the unfolding state is greater than the folded state, that is mainly due to the exposure of hydrophobic amino acids of the protein structure to the solvent molecules (PRABHU; SHARP, 2005).

Calorimetric enthalpy was obtained by integrating the area under the peak before the baseline subtraction (Figure 23a) and the value corresponds to the enthalpy at the Tm when there is an equilibrium between the folded and unfolded forms of the protein. The $\Delta \mathrm{H}^{\text {cal }}$ consists of endothermic and exothermic contributions correlated to the bonds and interactions disrupted by the heating process. The $\Delta \mathrm{H}^{\mathrm{VH}}$ was obtained when the fit of the raw data was done using a 
two-state scaled model (Figure $23 \mathrm{~b}$ ), this fit takes into account the equilibrium constant $\left(\mathrm{K}_{\mathrm{eq}}\right)$ considering that both forms of the protein are in perfect equilibrium.

In addition, the ratio $\Delta \mathrm{H}^{\mathrm{cal} /} \Delta \mathrm{H}^{\mathrm{VH}}$ of the enthalpies was obtained aiming to identify if the unfolding process of $\mathrm{Cz}$ follows a two-state model, without the formation of intermediates. If $\Delta \mathrm{H}^{\text {cal }}$ is equal to $\Delta \mathrm{H}^{\mathrm{VH}}$ the unfolding process follows a two-state model, but if $\Delta \mathrm{H}^{\text {cal }}$ were greater or lower than $\Delta \mathrm{H}^{\mathrm{VH}}$ the thermal unfolding may occur through the presence of an intermediate (BRUYLANTS; WOUTERS; MICHAUX, 2005).

The Tm of the unfolding process, the calorimetric enthalpy $\left(\Delta \mathrm{H}^{\mathrm{cal}}\right)$ and the Van't Hoff enthalpy $\left(\Delta \mathrm{H}^{\mathrm{VH}}\right)$, are shown in Table 6 , as long as the $\Delta \mathrm{H}^{\mathrm{cal} /} \Delta \mathrm{H}^{\mathrm{VH}}$ ratio.

Table 6: Experimental results of $\mathrm{Cz}$ thermal denaturation. All values are an average of four independent experiments.

\begin{tabular}{c|c|c|c|}
$\mathbf{T m}\left({ }^{\circ} \mathbf{C}\right)$ & $\Delta \mathbf{H}^{\mathrm{cal}}(\mathbf{k c a l} / \mathbf{m o l})$ & $\mathbf{\Delta} \mathbf{H}^{\mathrm{VH}}(\mathbf{k c a l} / \mathbf{m o l})$ & $\Delta \mathbf{H}^{\mathrm{cal} /} \mathbf{\Delta} \mathbf{H}^{\mathrm{VH}}$ \\
\hline $66.4 \pm 0.1$ & $100 \pm 5$ & $113 \pm 12$ & 0.9 \\
\hline
\end{tabular}

As shown in Table 6, the ratio $\Delta \mathrm{H}^{\mathrm{cal} /} \Delta \mathrm{H}^{\mathrm{VH}}$ is very close to 1.0 and the standard deviation of the analysis indicates that both enthalpies can be equal, and the process of unfolding can be considered of two states with an equilibrium constant equal to 1 . So, as the enthalpy values are close, a thermal unfolding without the presence of intermediates was considered for $\mathrm{Cz}$.

Afterward, the analysis proceeded to the investigation of the thermal unfolding of $\mathrm{Cz}$ in the presence of different ligands (Table 2). The parameters obtained are shown in the Table below.

Table 7: Experimental results obtained for fourteen compounds when incubated with $\mathrm{Cz}$ and analyzed by DSC. The $\Delta \mathrm{Tm}$ was obtained by subtracting the Tm of the incubated protein by the Tm of the native protein. The conditions for the assays were the same used for native cruzain assays with the only difference being the presence of the ligands. The mean values of the two measurements are presented.

\begin{tabular}{|c|c|c|c|c|c|}
\hline Ligand & $\mathbf{T m}\left({ }^{\circ} \mathbf{C}\right)$ & $\begin{array}{c}\Delta \mathbf{T m} \\
\left({ }^{\circ} \mathbf{C}\right)\end{array}$ & $\begin{array}{c}\mathbf{\Delta H}^{\text {Cal }} \\
(\mathbf{k c a l} / \mathbf{m o l})\end{array}$ & $\begin{array}{c}\mathbf{\Delta H}^{\mathbf{V H}} \\
(\mathbf{k c a l} / \mathbf{m o l})\end{array}$ & $\mathbf{\Delta H}^{\mathbf{c a l}} / \mathbf{\Delta H}^{\mathbf{V H}}$ \\
\hline $\mathbf{N e q 0 5 3 3 . 1}$ & 76.7 & 10.5 & $105 \pm 6$ & $189 \pm 13$ & 0.5 \\
\hline $\mathbf{N e q 0 5 6 9 . 2}$ & 79.3 & 13.1 & $117 \pm 2$ & $196 \pm 7$ & 0.6 \\
\hline Neq0570 & 72.5 & 6.1 & $115 \pm 2$ & $133 \pm 2$ & 0.8 \\
\hline Neq0635.1 & 76.4 & 10.2 & $107 \pm 6$ & $193 \pm 12$ & 0.5 \\
\hline Neq0643.1 & 79.7 & 13.5 & $127 \pm 15$ & $187 \pm 2$ & 0.7 \\
\hline Neq0818 & 76.9 & 10.7 & $128 \pm 28$ & $191 \pm 12$ & 0.7 \\
\hline Neq0865 & 75.0 & 8.8 & $68 \pm 2$ & $190 \pm 22$ & 0.4 \\
\hline Neq0866 & 76.2 & 10.0 & $93 \pm 2$ & $185 \pm 9$ & 0.5 \\
\hline Neq0922 & 77.1 & 10.9 & $125 \pm 13$ & $178 \pm 11$ & 0.7 \\
\hline Neq0925 & 76.7 & 10.5 & $92 \pm 2$ & $190 \pm 4$ & 0.5 \\
\hline Neq0937 & 76.2 & 10.0 & $75 \pm 2$ & $198 \pm 12$ & 0.4 \\
\hline Neq0940 & 76.8 & 10.6 & $88 \pm 2$ & $202 \pm 12$ & 0.4 \\
\hline
\end{tabular}




\begin{tabular}{|l|l|l|l|l|l|}
\hline Neq0942 & 75.8 & 9.60 & $77 \pm 5$ & $212 \pm 15$ & 0.4 \\
\hline Neq0954 & 76.6 & 10.4 & $74 \pm 3$ & $188 \pm 9$ & 0.4 \\
\hline
\end{tabular}

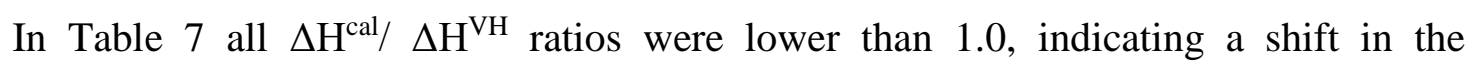
equilibrium of the process. The Tm values are higher than that obtained for the native protein, showing that the ligands are interacting with the folded protein, therefore, stabilizing $\mathrm{Cz}$ structure. The positive shift indicates that the equilibrium constant was displaced to the folded form due to the stabilization of the $\mathrm{Cz}$ structure. Because of that, when $\mathrm{Cz}$ is bound to the ligands the thermal unfolding probably occurred through the presence of an intermediate and the two domains may unfold separately but not independently as only one peak was observed. Figure 24 shows the Gaussian obtained for $\mathrm{Cz}$ bound to Neq0569.2, one that best stabilizes $\mathrm{Cz}$.

Figure 24: Cruzain unfolding peak when incubated with Neq0569.2 obtained after the correction of the blank (buffer-buffer), the blue line corresponds to the raw data obtained and the red line is the adjustment of the curve using a Two-State Scaled model. The solution was heated from 0 to $90{ }^{\circ} \mathrm{C}$ in acetate buffer $\mathrm{pH}=5.5,3 \mathrm{~atm}$ and a rate of $2{ }^{\circ} \mathrm{C} / \mathrm{min}$.

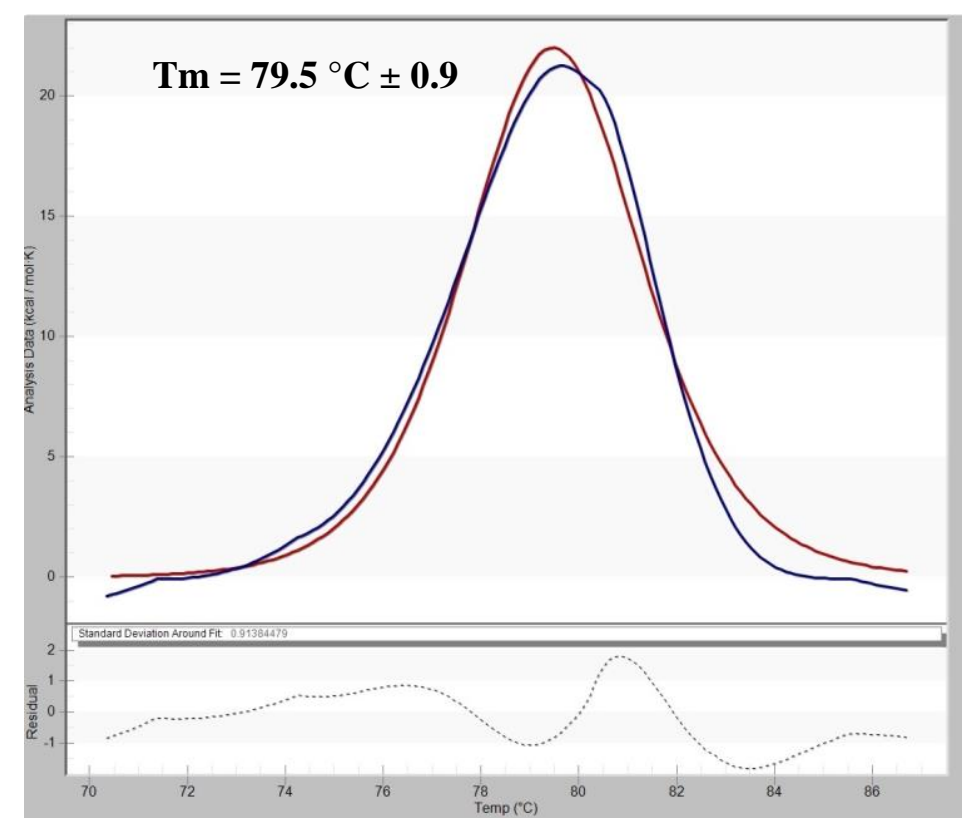

The $\Delta \mathrm{Cp}$ for the unfolding of $\mathrm{Cz}$ in the presence of the ligands varied between positive and negative values. A negative $\triangle \mathrm{Cp}$ characterizes polar solvation (PRABHU; SHARP, 2005) that was noticed for compounds that have more atoms capable of accepting hydrogen bonds, being the case for ligands with the $\mathrm{CF}_{3}$ and pyrazole groups.

A positive temperature shift, like the one obtained in Figure 24, is believed to be proportional to the affinity of a ligand. A plot of $\mathrm{p} K_{\mathrm{i}}$ versus $\Delta \mathrm{Tm}$ (Figure 25 ) was made to identify a possible correlation among the two parameters. 
Figure 25: Scatter plot correlating affinity $\left(\mathrm{p} K_{\mathrm{i}}\right)$ and thermal stability $(\Delta \mathrm{Tm})$ of $\mathrm{Cz}$ with fourteen inhibitors.

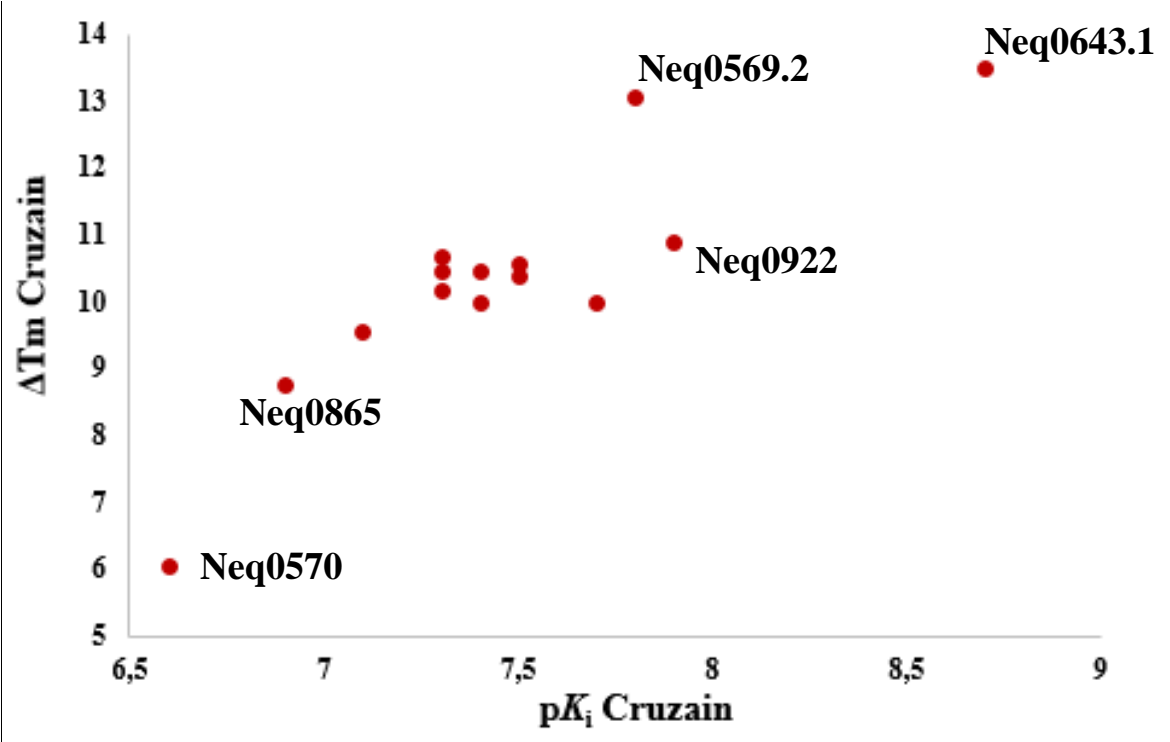

The scattered points suggest a linear trend that, however, should be further investigated. Neq0570 and Neq0865 which have the lowest $\mathrm{p} K_{\mathrm{i}}$ values, 6.7 and 6.9 respectively, were the only ones that present a $\Delta \mathrm{Tm}$ lower than $10^{\circ} \mathrm{C}$. This may be due to the less quantity of groups/atoms that are H-bond acceptors in these compounds, making the inhibitors to perform fewer interactions with the protein when compared with the rest of the ligands.

Most of the ligands have $\mathrm{p} K_{\mathrm{i}}$ between 7.0 and 8.0, because of that, the $\Delta \mathrm{Tm}$ did not suffer significant changes being around 9.5 to $11^{\circ} \mathrm{C}$.

The most potent ligand of the series against $\mathrm{Cz}$, Neq0643.1 ( $K_{\mathrm{i}}=8.7$ ) was able to thermally stabilized $\mathrm{Cz}$ structure in $13.5{ }^{\circ} \mathrm{C}$. This molecule has $6 \mathrm{H}$-bond acceptors groups/atoms in its structure, different from the other molecules that have between 3 and 4, being Neq0635.1 the only exception (it has also 6 H-bond acceptors). This may be one of the reasons for its high affinity and capability to stabilize $\mathrm{Cz}$.

Neq0922 $\left(\mathrm{p} K_{\mathrm{i}}=7.9\right)$, that has a similar affinity for $\mathrm{Cz}$ as Neq0569.2, stabilized $\mathrm{Cz}$ structure two degrees lower than Neq0569.2. Both ligands have the same moieties at the P3 and $\mathrm{P} 2$ positions, but differ in the $\mathrm{P} 1$. The ligands must have a different pose when bound to the enzyme, as Neq0922 have a moiety in P1 that goes to the S1' pocket. Furthermore, Neq0569.2 and Neq0643.1 have almost $1.0 \mathrm{log}$ unit of differences in $\mathrm{p} K_{\mathrm{i}}$ and their structures lack similarity, however, they have almost the same $\Delta \mathrm{Tm}$. A molecular docking study could be performed to identify the possible reasons for these results, evaluating the pose that these molecules have when in the protein's active site. 


\section{CONCLUSION}

In this work, we have identified covalent reversible inhibitors with high affinity for protozoan and mammalian CPs which are involved in different disease states. A high efficient protocol was implemented to test several reversible inhibitors for a panel of CPs. Structural modifications in P1, P2 and P3 positions in a dipeptidyl nitrile scaffold were performed and analyzed through an MMP/SAR analysis.

The P1 position exhibits a preference for the $S$ stereochemistry. A great loss in the affinity of the inhibitors was observed when the $R$ configuration was employed, independently of the functional group in that position. Overall, the cyclopropane at P1 was more effective than the (S)-benzyl, improving the ability of inhibition for the five CPs. The threonine residue at P1 displayed less gain in affinity than the Thr-O-Bn. An improvement in affinity was observed when using the Thr-O-Bn moiety for $\mathrm{Cz}, \mathrm{LmCPB}$, and $h \mathrm{CatS}$, while no change was noticed for $h$ CatL and $h$ CatK. The Thr-O-Bn moiety in $\mathrm{P} 1$ is an attractive group for targeting $h$ CatS selectively since an increase of one hundredfold in affinity was observed for Neq0922. The $(S)$ benzyl at P1 showed to be an interesting group when combined with the trifluoro ethylamine moiety at the $\mathrm{P} 3 / \mathrm{P} 2$ position. When both moieties were used, a gain of more than $1.0 \log$ unit was observed for the five CPs.

Switching Phe to a Leu on P2, when combined with a phenyl group in P3, an improvement in affinity for three CPs is observed, with a minor effect on $L m C P B$ and $h$ CatL. When Leu is on P2 and 3-(tert-butyl)-1-methyl-1H-pyrazole sitting on P3, a high increase in some CPs affinities is observed, especially for $h$ CatK. Nonetheless, there is a decrease in the $\mathrm{p} K_{\mathrm{i}}$ value for $h$ CatL. Therefore, these combinations can be explored to get high affinity and selective inhibitors for $h \mathrm{CatK}$ and $h$ CatL.

In summary, the 3-(tert-butyl)-1-methyl-1H-pyrazole is an attractive group at the P3 position for four CPs. For $h$ CatS, this moiety at P3 brought no gain in affinity being the phenyl group more compelling for this enzyme. The stereochemistry of the $\mathrm{CF}_{3}$ group in $\mathrm{P} 3 / \mathrm{P} 2$ brought an interesting result, in which both configurations were tolerable. A slight preference for the $S$ configuration was noticed for $\mathrm{Cz}, L m \mathrm{CPB}$, and $h \mathrm{CatK}$, while the $R$ were preferred for $h \mathrm{CatL}$ and $h$ CatS. Thanks to our structural analysis, we have identified that P3/P2 modifications strongly influence the possible mode of interaction of inhibitors. There is better accommodation on the site and thus a greater capacity for inhibition. 
Neq0643.1 is the most potent inhibitor of this work with a $\mathrm{p} K_{\mathrm{i}}$ ranging from 8.6 and 8.8 for the five CPs, being a very interesting inhibitor for these enzymes. It is hard to say the reasons for the lack of selectivity observed for Neq0643.1.

In general, compounds displayed low selectivity amid the five CPs. The most important inhibitors were Neq0642, Neq0533.1, Neq0866.1, Neq0954, and Neq0942 achieving a difference in affinity of more than $2.0 \log$ units. Additionally, Neq0642 was the best selective inhibitor for the protozoan CPs. For the mammalian CPs, the structural features of Neq0533.1, Neq0866.1, and Neq0954 can be explored to achieve selectivity among the cathepsins, focusing on $h$ CatL.

An irreversible unfolding was observed for $\mathrm{Cz}$ along with a two-state unfolding process. Ligands that displayed the highest thermal stabilization of $\mathrm{Cz}$ were Neq0569.2 and Neq0643.1 with over $13{ }^{\circ} \mathrm{C}$. Other ligands have shown similar $\Delta \mathrm{Tm}$, ranging from 6.0 to $11^{\circ} \mathrm{C}$. Moreover, a might linear trend was observed between $\mathrm{p} K_{\mathrm{i}}$ and $\Delta \mathrm{Tm}$ values. However, further studies should be carried out to better understand these correlations at the molecular level.

Overall, this work has provided information on mammalian and protozoan $\mathrm{CP}$ preferences for dipeptidyl nitrile class inhibitors and how to obtain selectivity among them. Hence, with MMP/SAR analysis, we were able to discover and improve the knowledge of crossclass inhibitors for CPs within a number of structural transformations. Our efforts now offer the opportunity to plan new chemical entities (NCEs) directly, without resorting to expensive random testing campaigns. 


\section{REFERENCES}

ÁBRÁNYI-BALOGH, P.; PETRI, L.; IMRE, T.; SCARPINO, A.; HRAST, M.; MITROVIC, A.; FONOVIC, U. P.; NEMETH, K.; BARRETEAU, H.; ROPER, D.I.; HORVATI, K.; FRENCZY, G. G.; KOS, J.; ILAS, J.; GOBEC, S.; KESERU, G. M. A road map for prioritizing warheads for cysteine targeting covalent inhibitors. European Journal of Medicinal Chemistry, Issy les Moulineaux Cedex v. 160, p. 94-107, dez. 2018.

ABU-DAYYEH, I.; HASSANI, K.; WESTRA, E. R.; MOTTRAM, J.; OLIVIER, M. Comparative study of the ability of Leishmania mexicana Promastigotes and Amastigotes to alter macrophage signaling and functions. Infection and Immunity, Washington, v. 78, n. 6, p. $2438-2445,1$ jun. 2010.

AINSCOUGH, J. S.; MACLEOD, T.; BRAKEFIELD, R.; BARON, J. M.; ALASE, A.; WITTMANN, M.; STACEY, M. Cathepsin $\mathrm{S}$ is the major activator of the psoriasis-associated proinflammatory cytokine IL-36 $\gamma$. Proceedings of the National Academy of Sciences, Washington, v. 114, n. 13, p. E2748-E2757, 28 mar. 2017.

ARAFET, K.; FERRER, S.; MOLINER, V. Computational study of the catalytic mechanism of the cruzain cysteine protease. ACS Catalysis, Washington, v. 7, n. 2, p. 1207-1215, 3 fev. 2017.

ASAAD, N.; BETTEL, P. A.; COULSON, M. D.; DAWSON, J. E.; FORD, S.J.; GREHARDT, S.; GRIST, M.; HAMLIN, G. A.; JAMES, M. J.; JONES, E. V.; KAROUTCHI, G. I.; KENNY, P. W.; MORLEY, A. D.; OLDHAM, K.; RANKINE, N.; RYAN, D.; WELLS, S. L.; WOOD, L.; AUGUSTIN, M.; KRAPP. S.; SIMADER, H.; STEINBACHER, S. Dipeptidyl nitrile inhibitors of Cathepsin L. Bioorganic \& Medicinal Chemistry Letters, Oxford, v. 19, n. 15, p. 4280-4283, ago. 2009.

ATKINSON, H. J.; BABBITT, P. C.; SAJID, M. The global cysteine peptidase landscape in parasites. Trends in Parasitology, Oxford, v. 25, n. 12, p. 573-581, dez. 2009.

AVELAR, L. A. A.; CAMILO, C. D.; ALBUQUERQUE, S.; FERNANDES, W. B.; GONÇALEZ, C.; KENNY, P. W.; LEITÃO, A.; MCKERROW, J. H.; MONTANARI, C.A., OROZCO, E. V. M.; RIBEIRO, J. F. R.; ROCHA, J. R.; ROSINI, F.; SAIDEL, M. E. Molecular design, synthesis and trypanocidal activity of dipeptidyl nitriles as cruzain inhibitors. PLOS Neglected Tropical Diseases, San Francisco, v. 9, n. 7, p. e0003916, 14 jul. 2015.

BAILlIE, T. A. Targeted covalent inhibitors for drug design. Angewandte Chemie International Edition, Weinheim, v. 55, n. 43, p. 13408-13421, 17 out. 2016.

BARBOZA, M.; DUSCHAK, V. G.; FUKUYAMA, Y.; NONAMI, H.; ERRA-BALSELLS, R.; CAZZULO, J. J.; COUTO, A. S. Structural analysis of the N-glycans of the major cysteine proteinase of Trypanosoma cruzi: identification of sulfated high-mannose type oligosaccharides. FEBS Journal, Chichester, v. 272, n. 15, p. 3803-3815, 22 jul. 2005.

BEAUlIEU, C.; ISABEL, E.; FORTIER, A.; MASSÉ, F.; MELLON, C.; MÉTHOT, N.; NDAO, M.; NICOLL-GRIFFITH, D.; LEE, D.; PARK, H.; BLACK, W. C. Identification of potent and reversible cruzipain inhibitors for the treatment of Chagas disease. Bioorganic \& Medicinal Chemistry Letters, Oxford, v. 20, n. 24, p. 7444-7449, dez. 2010. 
BERTEOTTI, A.; VACONDIO, F.; LODOLA, A.; BASSI, M.; SILVA, C.; CAVALLI, A. Predicting the reactivity of nitrile-carrying compounds with cysteine: a combined computational and experimental study. ACS Medicinal Chemistry Letters, Washington, v. 5, n. 5, p. 501-505, 8 maio 2014.

BIRCH, A. M.; KENNY, P. W.; SIMPSON, I.; WHITTAMORE, P. R. Matched molecular pair analysis of activity and properties of glycogen phosphorylase inhibitors. Bioorganic \& Medicinal Chemistry Letters, Oxford, v. 19, n. 3, p. 850-853, fev. 2009.

BRUYLANTS, G.; WOUTERS, J.; MICHAUX, C. Differential scanning calorimetry in life science: thermodynamics, stability, molecular recognition and application in drug design. Current Medicinal Chemistry, Sharjah, v. 12, n. 17, p. 2011-2020, 1 ago. 2005.

CHEN, L.; LU, B.; YANG, Y.; ZHANG, W.; WANG, X.; ZHOU, H.; WEN, J.; YANG, Z.; $\mathrm{HU}, \mathrm{R}$. Elevated circulating cathepsin $\mathrm{S}$ levels are associated with metabolic syndrome in overweight and obese individuals. Diabetes/Metabolism Research and Reviews, Oxford, p. e3117, 14 dez. 2018.

CHOE, Y.; LEONETTI, F.; GREENBAUM, D. C.; LECAILLE, F.; BOGYO, M.; BROMME, D.; ELLMAN, J. A.; CRAIK, C. S. Substrate profiling of cysteine proteases using a combinatorial peptide library identifies functionally unique specificities. Journal of Biological Chemistry, Bethesda, v. 281, n. 18, p. 12824-12832, 5 maio 2006.

CIANNI, L.; SARTORI, G.; ROSINI, F.; DE VITA, D.; PIRES, G.; LOPES, B. R.; LEITÃO A.; BURTOLOSO, A. C.; MONTANARI, C. A. Leveraging the cruzain S3 subsite to increase affinity for reversible covalent inhibitors. Bioorganic Chemistry, Maryland Heights, v. 79, p. 285-292, set. 2018.

CIANNI, L.; FELDMANN, C. W.; GILBERG, E.; GUTSCHOW, M.; JULIANO, L.; LEITÃO, A.; BAJORATH, J.; MONTANARI, C. A. Can cysteine protease cross-class inhibitors achieve selectivity? Journal of Medicinal Chemistry, Washington, [2019?]. No prelo.

CONAGHAN, P. G.; OWES, M. A.; KINGSBURY, S. R.; BRETT, A.; GUILLARD, G.; TUNBLAS, K.; RIZOSKA, B.; LARSSON, T.; HOLMGREN, A.; MANNINEN, A.; GOHLIN, K.; HEBER, W.; GRAHAM, P.; JANSSON, A.; WADELL, C.; BETHELL, R.; OHD, J. Six months' treatment with MIV-711, a novel Cathepsin K inhibitor induces osteoarthritis structure modification: results from a randomized double-blind placebocontrolled phase IIA trial. Osteoarthritis and Cartilage, London, v. 26, p. S25-S26, abr. 2018.

DA SILVA, E. B.; DO NASCIMENTO PEREIRA, G. A.; FERREIRA, R. S. Trypanosomal cysteine peptidases: target validation and drug design strategies. In: MÜLLER, S.; CERDAN, R.; RADULESCU, O. (ed.). Comprehensive analysis of parasite biology: from metabolism to drug discovery. Weinheim: Wiley-VCH, 2016. p. 121-145.

DE CESCO, S.; KURIAN, J.; DUFRESNE, C.; MITTERMAIER, A. K.; MOITESSIER, N. Covalent inhibitors design and discovery. European Journal of Medicinal Chemistry, Issy les Moulineaux Cedex, v. 138, p. 96-114, set. 2017. 
DE LUCA, L.; FERRO, S.; BUEMI, M. R.; MONFORTE, A. M.; GITTO, R.; SCHIRMEISTER, T.; MAES, L. RESCIFINA, A.; MICALE, N. Discovery of benzimidazolebased Leishmania mexicana cysteine protease CPB2.8 $\triangle \mathrm{CTE}$ inhibitors as potential therapeutics for leishmaniasis. Chemical Biology \& Drug Design, Hoboken, v. 92, n. 3, p. 1585-1596, set. 2018.

DENNEMÄRKER, J.; LOHMULLER, T.; MAYERLE, J.; TACKE, M.; LERCH, M. M.; COUSSENS, L. M.; PETERS, C.; REINHECKEL, T. Deficiency for the cysteine protease cathepsin L promotes tumor progression in mouse epidermis. Oncogene, London, v. 29, n. 11, p. 1611-1621, mar. 2010.

DEU, E.; VERDOES, M.; BOGYO, M. New approaches for dissecting protease functions to improve probe development and drug discovery. Nature Structural \& Molecular Biology, New York, v. 19, n. 1, p. 9-16, jan. 2012.

DOYLE, P. S.; ZHOU, Y. M.; HSIEH, I.; GREENBAUM, D. C.; MCKERROW, J. H.; ENGEL, J. C. The Trypanosoma cruzi protease cruzain mediates immune evasion. PLoS Pathogens, San Franscico, v. 7, n. 9, p. e1002139, 1 set. 2011.

DRAG, M.; SALVESEN, G. S. Emerging principles in protease-based drug discovery. Nature Reviews Drug Discovery, London, v. 9, n. 9, p. 690-701, set. 2010a.

DRAG, M.; SALVESEN, G. S. Emerging principles in protease-based drug discovery. Nature Reviews Drug Discovery, London, v. 9, n. 9, p. 690-701, set. 2010 b.

FLEMING, F. F.; YAO, L.; RAVIKUMAR, P. C.; FUNK, L.; SHOOK, B. C. Nitrilecontaining pharmaceuticals: efficacious roles of the nitrile pharmacophore. Journal of Medicinal Chemistry, Washington, v. 53, n. 22, p. 7902-7917, 25 nov. 2010.

FOTI CUZZOLA, V.; PALlELA, E.; CELI, D.; BARRESI, M.; GIACOPPO, S.; BRAMANTI, P.; MARINO, S. Pharmacogenomic update on multiple sclerosis: a focus on actual and new therapeutic strategies. The Pharmacogenomics Journal, London, v. 12, n. 6, p. 453-461, dez. 2012.

FRIZLER, M.; LOHR, F.; FURTMANN, N.; KLAS, J.; GUTSCHOW, M. Structural optimization of azadipeptide nitriles strongly increases association rates and allows the development of selective cathepsin inhibitors. Journal of Medicinal Chemistry, Washington, v. 54, n. 1, p. 396-400, 13 jan. 2011.

FUCHS, J. E.; WELLENZOHN, B.; WESKAMP, N.; LIED, K. R. Matched peptides: tuning matched molecular pair analysis for biopharmaceutical applications. Journal of Chemical Information and Modeling, Washington, v. 55, n. 11, p. 2315-2323, 23 nov. 2015.

GAULTON, A.; HERSEY, A.; NOWOTKA, M.; BENTO, P.; CHAMBERS, J.; MENDES, D.; MUTOWO, P.; ATKINSON, F.; BELLIS, L. J.; CIBRIAN-UHALTE, E.; DAVIES, M.; DEDMAN, N.; KARLSSON, A.; MAGARINOS, M. P.; OVERINGTON, J. P.; PAPADATOS, G.; SMIT, I.; LEACH, A. R. The ChEMBL database in 2017. Nucleic Acids Research, Oxford, v. 45, n. D1, p. D945-D954, 4 jan. 2017.

GILLMOR, S. A.; CRAIK, C. S.; FLETTERICK, R. J. Structural determinants of specificity in the cysteine protease cruzain. Protein Science, Hoboken, v. 6, n. 8, p. 1603-1611, ago. 1997. 
GRIFFEN, E.; LEACH, A. G.; ROBB, G. R.; WARNER, D. J. Matched molecular pairs as a medicinal chemistry tool: miniperspective. Journal of Medicinal Chemistry, Washington, v. 54, n. 22, p. 7739-7750, 24 nov. 2011.

GUHA, R. On Exploring structure-activity relationships. In: KORTAGERE, S. (ed.). In silico models for drug discovery. Totowa: Humana Press, 2013. v. 993, p. 81-94.

HASANBASIC, S.; JAHIC, A.; KARAHMET, E.; SEJRANIC, A.; PRNJAVORAC, B. The role of cysteine protease in Alzheimer disease. Materia Socio Medica, Sarajevo, v. 28, n. 3, p. $235,2016$.

HERRERA-MAYORGA, V.; LARA-RAMIREZ, E. E.; CHACON,VARGAS, K. F.; AGUIRRE-ALVARADO， C.; RODRIGUEZ-PAEZ， L.; ALCANTARA-FARFAN, V,; CORDERO-MARTINEZ, J.; NOGUEDA-TORRES, B.; REYES-ESPINOSA, F.; BOCANERA-GARCIA, V.; RIVERA, G. Structure-based virtual screening and in vitro evaluation of new Trypanosoma cruzi cruzain inhibitors. International Journal of Molecular Sciences, Basel, v. 20, n. 7, p. 1742, 9 abr. 2019.

JADHAV, P. K.; SCHIFFLER, M. A.; GAVARDINAS, K.; KIM, E. J.; MATTHEWS, D. P.; STASZAK, M. A.; COFFEY, D. S.; SHAW, B. W.; CASSIDY, K. C.; BRIER, R. A.; ZHANG, Y.; CHRISTIE, R. M.; MATLER, W. F.; QING, K.; DURBIN, J. D.; WANG, Y.; DENG, G. G. Discovery of cathepsin S inhibitor LY3000328 for the treatment of abdominal aortic aneurysm. ACS Medicinal Chemistry Letters, Washington, v. 5, n. 10, p. 1138-1142, 9 out. 2014.

KĘDZIOR, M.; SEREDYŃSKI, R.; GUTOWICZ, J. Microbial inhibitors of cysteine proteases. Medical Microbiology and Immunology, Heidelberg, v. 205, n. 4, p. 275-296, ago. 2016.

KRAMER, C.; FUCHS, J. E.; WHITEBREAD, S.; GEDECK, P.; LIEDL, K. R. Matched molecular pair analysis: significance and the impact of experimental uncertainty. Journal of Medicinal Chemistry, Washington, v. 57, n. 9, p. 3786-3802, 8 maio 2014.

KRAMER, L.; TURK, D.; TURK, B. The future of cysteine cathepsins in disease management. Trends in Pharmacological Sciences, Oxford, v. 38, n. 10, p. 873-898, out. 2017.

LINDSTRÖM, E.; RIZOSKA, B.; HENDERSON, I.; TERELIUS, Y.; JERLING, M.; EDENIUS, C.; GRABOWASKA, U. Nonclinical and clinical pharmacological characterization of the potent and selective cathepsin $\mathrm{K}$ inhibitor MIV-711. Journal of Translational Medicine, London, v. 16, n. 1, dez. 2018.

MCGRATH, M. E.; PALMER, J. T.; BROMME, D.; SOMOZA, J. R. Crystal structure of human cathepsin S. Protein Science, Hoboken, v. 7, n. 6, p. 1294-1302, jun. 1998.

MCKERROW, J. H.; DOYLE, P. S.; ENGEL, J. C.; PODUST, L. M.; ROBERTSON, S. A.; FERREIRA, R.; SAXTON, T.; ARKIN, M.; KERR, I. D.; BRINEN, L. S.; CRAIK, C. S. Two approaches to discovering and developing new drugs for Chagas disease. Memórias do Instituto Oswaldo Cruz, Rio de Janeiro, v. 104, n. suppl 1, p. 263-269, jul. 2009.

MCKERROW, J. H. The diverse roles of cysteine proteases in parasites and their suitability as drug targets. PLOS Neglected Tropical Diseases, San Francisco, v. 12, n. 8, p. e0005639, 23 ago. 2018. 
MOTTRAM, J. C.; BROOKS, D. R.; COOMBS, G. H. Roles of cysteine proteinases of trypanosomes and Leishmania in host-parasite interactions. Current Opinion in Microbiology, Oxford, v. 1, n. 4, p. 455-460, ago. 1998.

MULDER, W. J. M.; JAFFER, F. A.; FAYAD, Z. A.; NAHRENDORF, M. Imaging and nanomedicine in inflammatory atherosclerosis. Science Translational Medicine, Washington, v. 6 , n. 239, p. 239sr1-239sr1, 4 jun. 2014.

MULLARD, A. Merck \& Co. drops osteoporosis drug odanacatib. Nature Reviews Drug Discovery, London, v. 15, n. 10, p. 669-669, out. 2016.

OLSON, O. C.; JOYCE, J. A. Cysteine cathepsin proteases: regulators of cancer progression and therapeutic response. Nature Reviews Cancer, London, v. 15, n. 12, p. 712-729, dez. 2015 .

OTTO, H.-H.; SCHIRMEISTER, T. Cysteine proteases and their inhibitors. Chemical Reviews, Washington, v. 97, n. 1, p. 133-172, fev. 1997.

PAPADATOS, G.; ALKAROURI, M.; GILLET, V. J.; WILLETT, P.; KADIRKAMANATHAN, V.; LUSCOMBE, C. N.; BRAVI, G.; RICHMOND, N. J.; PICKETT, S. D.; HUSSAIN, J.; JOHN M. PRITCHARD, J. M.; COOPER, A. W. J.; SIMON J. F. MACDONALD, S. J. F. lead optimization using matched molecular pairs: inclusion of contextual information for enhanced prediction of herg inhibition, solubility, and lipophilicity. Journal of Chemical Information and Modeling, Washington, v. 50, n. 10, p. 1872-1886, 25 out. 2010.

POREBA, M.; RUT, W.; VIZOVISEK, M.; GROBORZ, K.; KASPERKIEWICZ, P.; FINLAY, D.; VUORI, K.; TURK, D.; TURK, B.; SALVESEN, G. S.; DRAG, M. Selective imaging of cathepsin L in breast cancer by fluorescent activity-based probes. Chemical Science, Cambridge, v. 9, n. 8, p. 2113-2129, 2018.

POWERS, J. C.; ASGIAN, J. L.; EKICI, O. D.; JAMES, K. E. Irreversible inhibitors of serine, cysteine, and threonine proteases. Chemical Reviews, Washington, v. 102, n. 12, p. 46394750, dez. 2002.

PRABHU, N. V.; SHARP, K. A. Heat capacity in proteins. Annual Review of Physical Chemistry, Palo Alto, v. 56, n. 1, p. 521-548, 5 maio 2005.

QUILlES JUNIOR, J. C.; BERNARDI, P.H.J.; SILVA, S. C. M.; ROCHA, C. M. R.; MONTANARI, C. A.; LEITÃO, A. Biological activity and physicochemical properties of dipeptidyl nitrile derivatives against pancreatic ductal adenocarcinoma cells. Anti-Cancer Agents in Medicinal Chemistry, Sharjah, v. 19, n. 1, p. 112-120, 8 maio 2019.

ROBINSON, M. W.; DALTON, J. P. (eds.). Cysteine proteases of pathogenic organisms. New York: Springer Science; Austin: Landes Bioscience, 2011.

ROGERS, K. E.; KERANEN, H.; DURRANT, J. D.; RATMAN, J.; DOAK, A.; ARKIN, M. R.; MCCAMMON, J. A. Novel cruzain inhibitors for the treatment of Chagas' Disease. Chemical Biology \& Drug Design, Hoboken, v. 80, n. 3, p. 398-405, set. 2012. 
SAJID, M.; ROBERTSON, S. A.; BRINEN, L. S.; MCKERROW, J. H. Cruzain. In: ROBINSON, M. W.; DALTON, J. P. (eds.). Cysteine proteases of pathogenic organisms. Boston: Springer, 2011. v. 712, p. 100-115.

SANDERSON, S. J.; POLLOCK, K. G.; HILLEY, J. D.; MELDAL, M.; HILAIRE, P. S.; JULIANO, M. A.; JULIANO, L.; MOTTRAM, J. C.; COOMBS, G. H. Expression and characterization of a recombinant cysteine proteinase of Leishmania mexicana. Biochemical Journal, London, v. 347, n. 2, p. 383, 15 abr. 2000.

SANI, M.; VOLONTERIO, A.; ZANDA, M. The Trifluoroethylamine Function as Peptide Bond Replacement. ChemMedChem, Weinheim, v. 2, n. 12, p. 1693-1700, 10 dez. 2007.

SIKLOS, M.; BENAISSA, M.; THATCHER, G. R. J. Cysteine proteases as therapeutic targets: does selectivity matter? A systematic review of calpain and cathepsin inhibitors. Acta Pharmaceutica Sinica B, Beijing, v. 5, n. 6, p. 506-519, nov. 2015.

SILVA, D. G.; RIBEIRO, J. F. R.; DE VITA, D.; CIANNI, L.; FRANCO, C. H.; FREITAS JUNIOR, L. H.; MORAES, C. B.; ROCHA, J. R.; BURTOLOSO, A. C.; KENNY, P. W.; LEITÃO, A.; MONTANARI, C. A. A comparative study of warheads for design of cysteine protease inhibitors. Bioorganic \& Medicinal Chemistry Letters, Oxford, v. 27, n. 22, p. 5031-5035, nov. 2017.

SINGH, J.; PETTER, R. C.; BAILLIE, T.A.; WHITTY, A. The resurgence of covalent drugs. Nature Reviews Drug Discovery, London, v. 10, n. 4, p. 307-317, abr. 2011.

SMITH, A. J. T.; ZHANG, X.; LEACH, A.G.; HOUK, K. N. Beyond picomolar affinities: quantitative aspects of noncovalent and covalent binding of drugs to proteins. Journal of Medicinal Chemistry, Washington, v. 52, n. 2, p. 225-233, 22 jan. 2009.

SOLÍS-MENDIOLA, S.; ROJO-DOMÍNGUEZ, A.; HERNÁNDEZ-ARANA, A. Cooperativity in the unfolding transitions of cysteine proteinases. Calorimetric study of the heat denaturation of chymopapain and papain. Biochimica et Biophysica Acta (BBA) - Protein Structure and Molecular Enzymology, Amsterdam, v. 1203, n. 1, p. 121-125, nov. 1993.

STONE, J. A.; MCCREA, J. B.; WITTER, R.; STOCH, S. S. Clinical and translational pharmacology of the cathepsin K inhibitor odanacatib studied for osteoporosis. British Journal of Clinical Pharmacology, Chichester, v. 85, n. 6, p. 1072-1083, jun. 2019.

STUMPFE, D.; BAJORATH, J. Exploring activity cliffs in medicinal chemistry: miniperspective. Journal of Medicinal Chemistry, Washington, v. 55, n. 7, p. 2932-2942, 12 abr. 2012.

TABISH, T.; PRANJOL, M. Z.; HORSELL, D. W.; RAHAT, A. A. M.; WHATMORE, J. L.; WINYARD, P. G.; ZHANG, S. Graphene oxide-based targeting of extracellular Cathepsin D and Cathepsin L as a novel anti-metastatic enzyme cancer therapy. Cancers, Basel, v. 11, n. 3, p. 319, 6 mar. 2019.

TALELE, T. T. The "Cyclopropane Fragment" is a versatile player that frequently appears in preclinical/clinical drug molecules. Journal of Medicinal Chemistry, Washington, v. 59, n. 19, p. 8712-8756, 13 out. 2016. 
TURK, V.; STOKA, V.; VASILJEVA, O.; RENKO, M.; SUN, T.; TURK, B.; TURK, D. Cysteine cathepsins: from structure, function and regulation to new frontiers. Biochimica et Biophysica Acta (BBA) - Proteins and Proteomics, Amsterdam, v. 1824, n. 1, p. 68-88, jan. 2012.

VERMA, S.; DIXIT, R.; PANDEY, K. C. Cysteine proteases: modes of activation and future prospects as pharmacological targets. Frontiers in Pharmacology, Lausanne, v. 7, p. 1-12, 25 abr. 2016.

WAWER, M.; BAJORATH, J. Local structural changes, global data views: graphical substructure-activity relationship trailing. Journal of Medicinal Chemistry, Washington, v. 54, n. 8, p. 2944-2951, 28 abr. 2011.

WILliAMS, R. A.; TETLEY, L.; MOTTRAM, J. C.; COOMBS, G. H. Cysteine peptidases CPA and CPB are vital for autophagy and differentiation in Leishmania mexicana. Molecular Microbiology, Chichester, v. 61, n. 3, p. 655-674, ago. 2006.

YUNG-CHI, C.; PRUSOFF, W. H. Relationship between the inhibition constant (KI) and the concentration of inhibitor which causes 50 per cent inhibition (I50) of an enzymatic reaction. Biochemical Pharmacology, Philadelphia, v. 22, n. 23, p. 3099-3108, dez. 1973.

ZAIDI, M.; TROEN, B.; MOONGA, B. S.; ABE, E. Cathepsin K, osteoclastic resorption, and osteoporosis therapy. Journal of Bone and Mineral Research, Hoboken, v. 16, n. 10, p. 17471749, 1 out. 2001.

ZHAI, X.; MEEK, T. D. Catalytic mechanism of cruzain from Trypanosoma cruzi as determined from solvent kinetic isotope effects of steady-state and pre-steady-state kinetics. Biochemistry, Washington, v. 57, n. 22, p. 3176-3190, 5 jun. 2018. 


\section{APPENDIX}

\section{APPENDIX A- KM ASSAYS}

- Cruzain assay replicates:

Figure 1: Cruzain velocity plot as a function of Z-Phe-Arg-AMC concentration adjusted in the Michaelis-Menten equation.

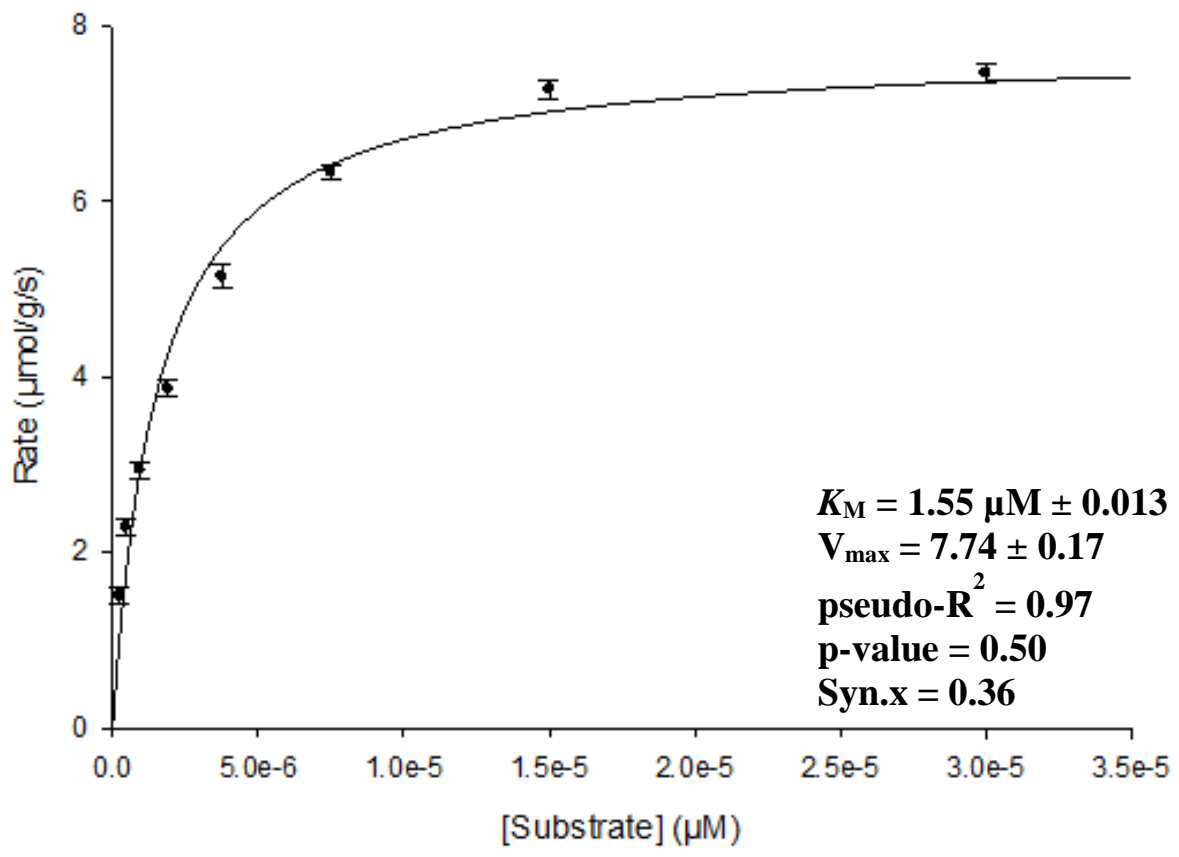

Figure 2: Cruzain velocity plot as a function of Z-Phe-Arg-AMC concentration adjusted in the Michaelis-Menten equation.

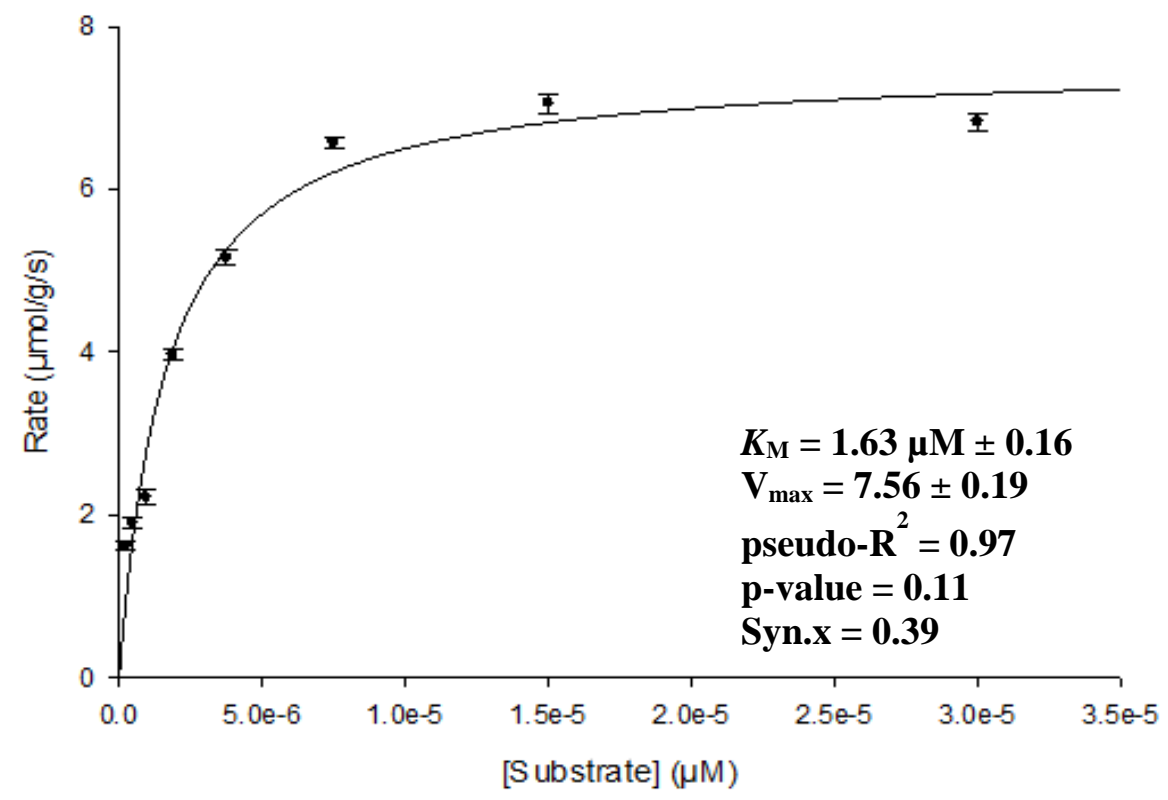


Figure 3: Cruzain velocity plot as a function of Z-Phe-Arg-AMC concentration adjusted in the Michaelis-Menten equation.

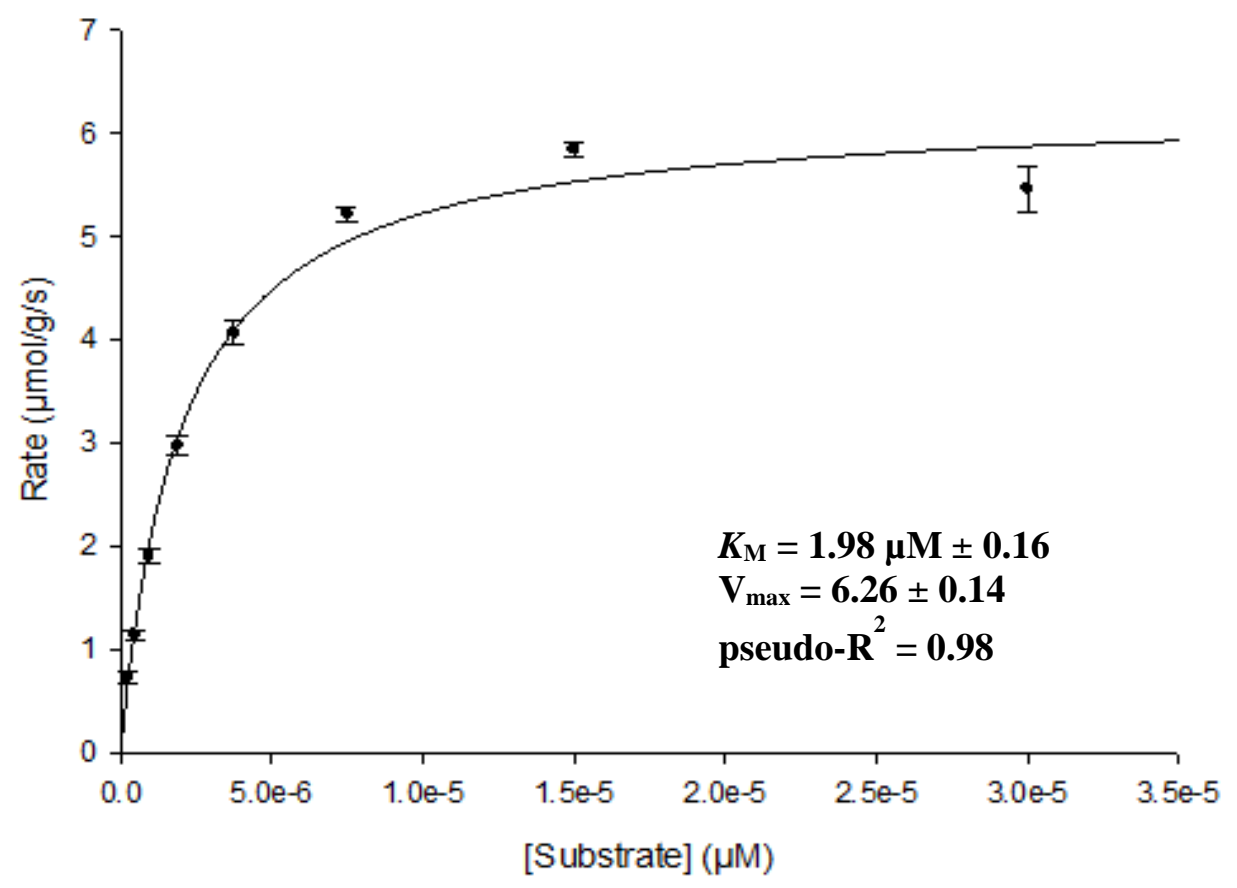

- $\quad L m C P B$ assay replicates:

Figure 4: $L m C P B$ velocity plot as a function of Z-Phe-Arg-AMC concentration adjusted in the Michaelis-Menten equation.

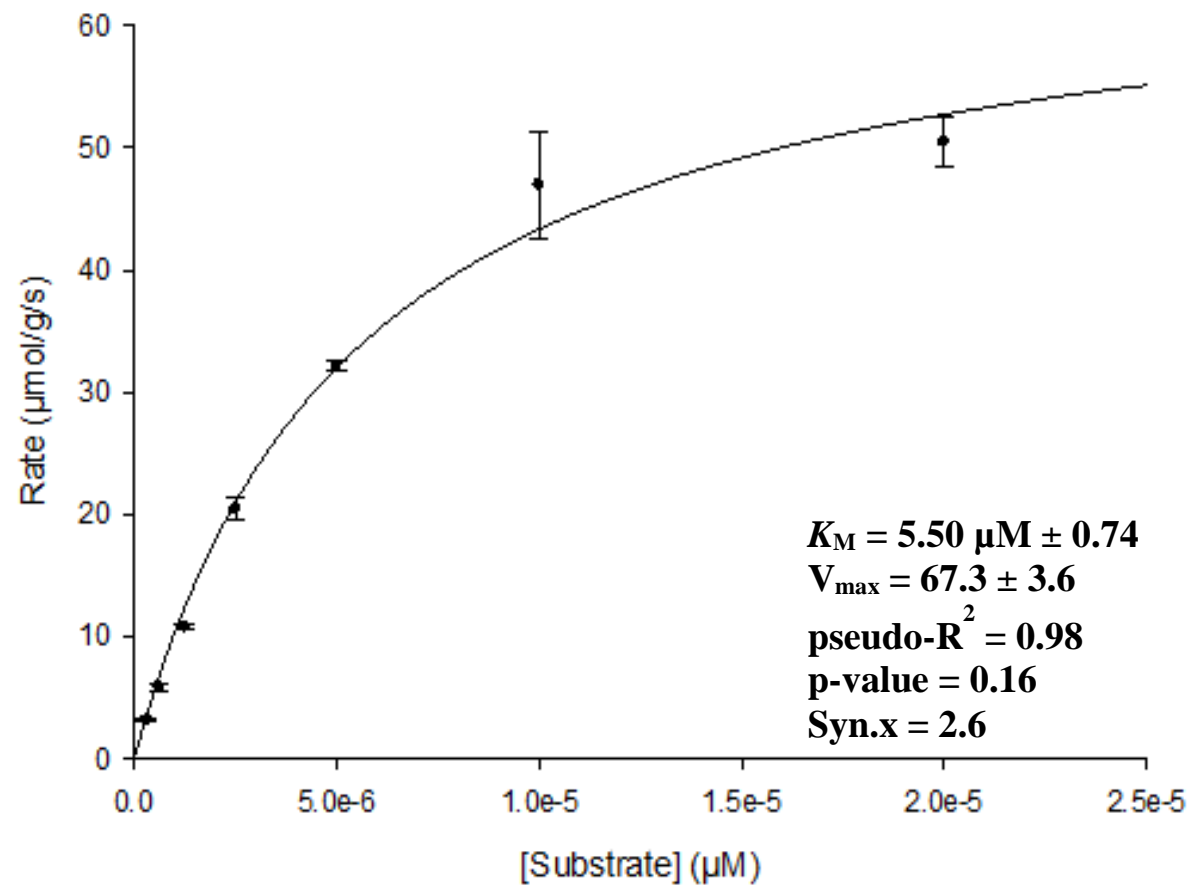


Figure 5: $L m \mathrm{CPB}$ velocity plot as a function of Z-Phe-Arg-AMC concentration adjusted in the Michaelis-Menten equation.

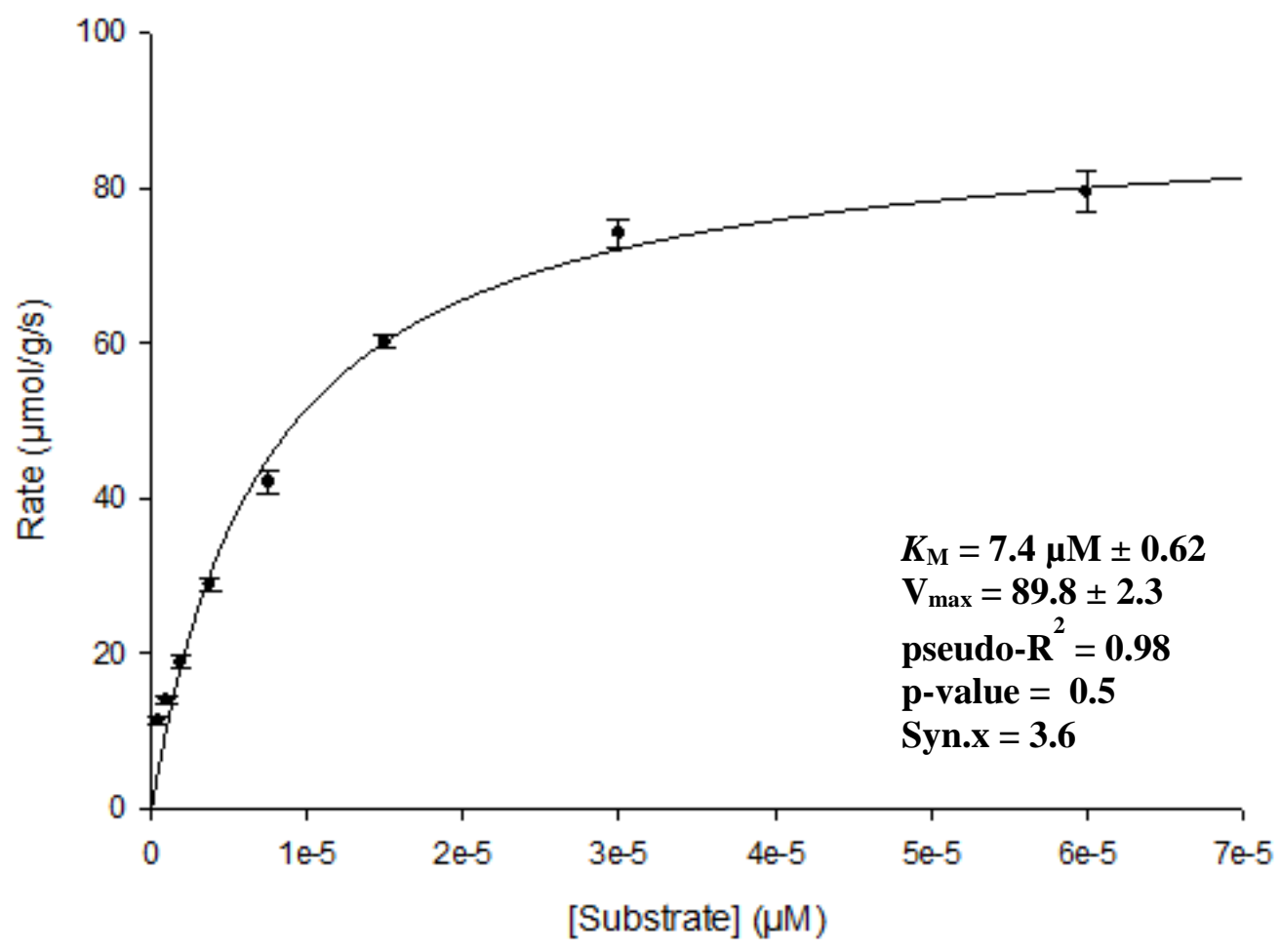

Figure 6: $L m C P B$ velocity plot as a function of Z-Phe-Arg-AMC concentration adjusted in the Michaelis-Menten equation.

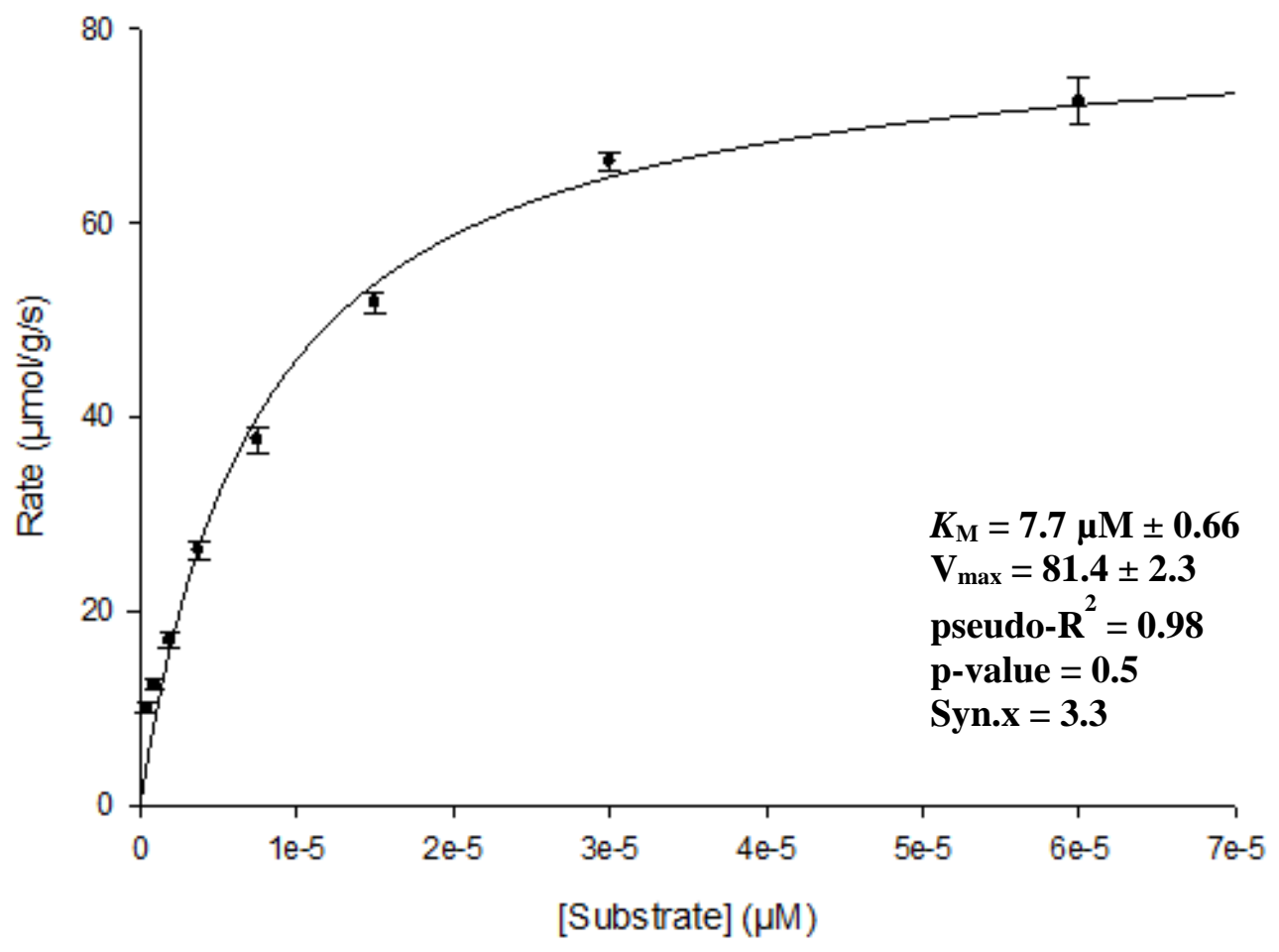


Figure 7: $\operatorname{LmCPB}$ velocity plot as a function of Z-Phe-Arg-AMC concentration adjusted in the Michaelis-Menten equation.

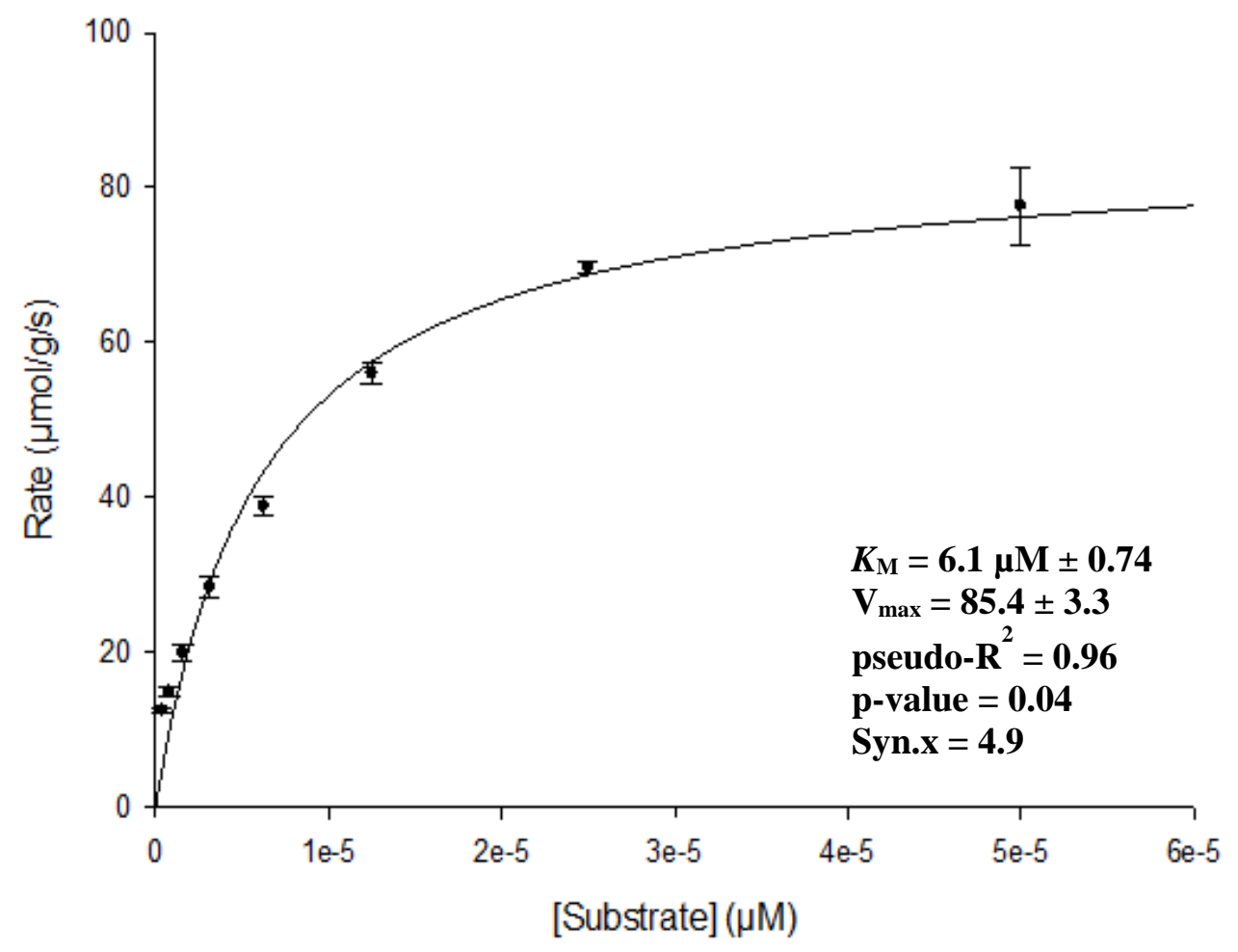

- $h$ CatL replicates:

Figure 8: $h$ CatL velocity plot as a function of Z-Phe-Arg-AMC concentration adjusted in the MichaelisMenten equation.

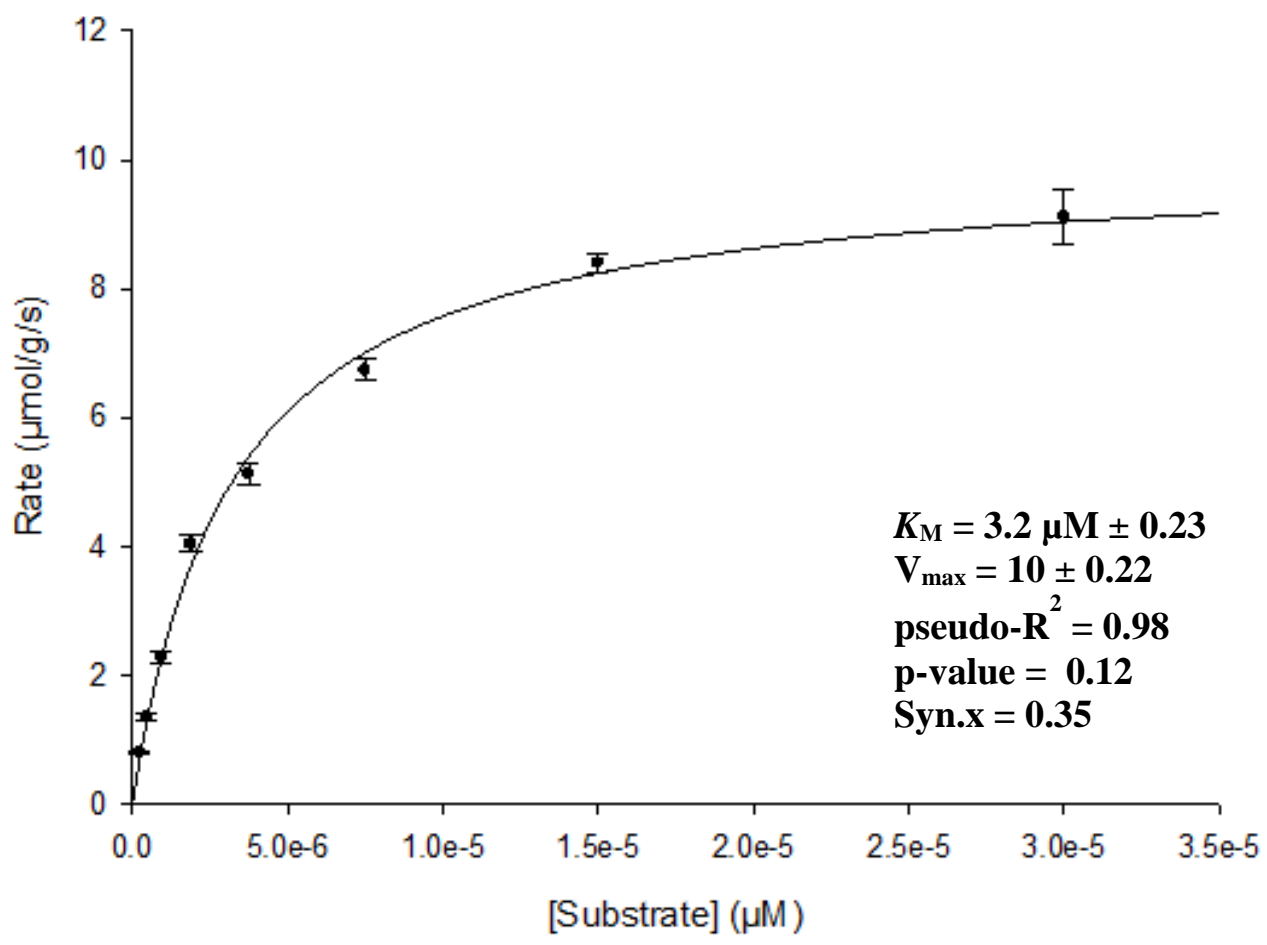


Figure 9: $h$ CatL velocity plot as a function of Z-Phe-Arg-AMC concentration adjusted in the MichaelisMenten equation.

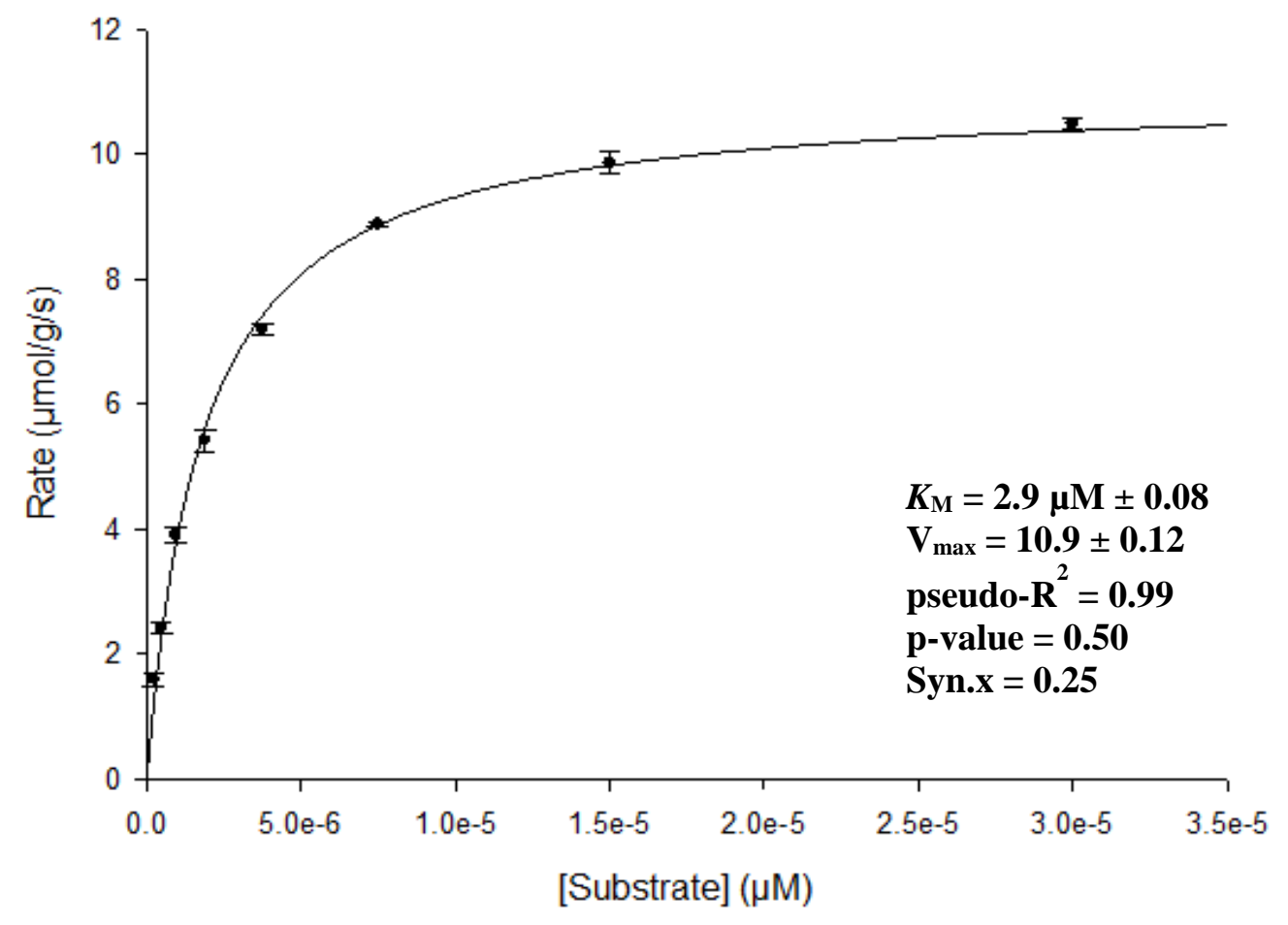

Figure 10: $h$ CatL velocity plot as a function of Z-Phe-Arg-AMC concentration adjusted in the MichaelisMenten equation.

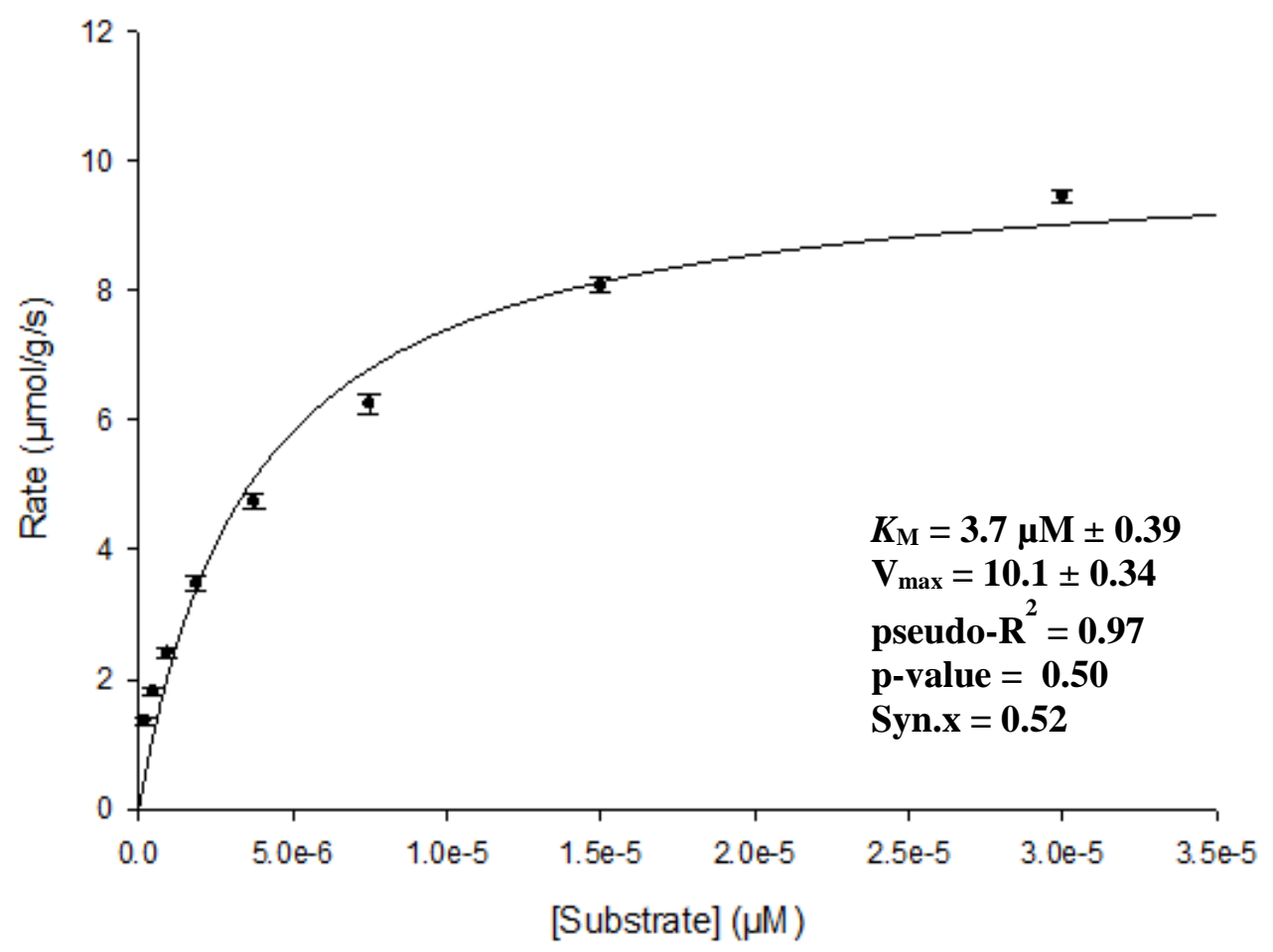


- $h$ CatS replicates:

Figure 11: $h$ CatS velocity plot as a function of Z-Phe-Arg-AMC concentration adjusted in the MichaelisMenten equation.

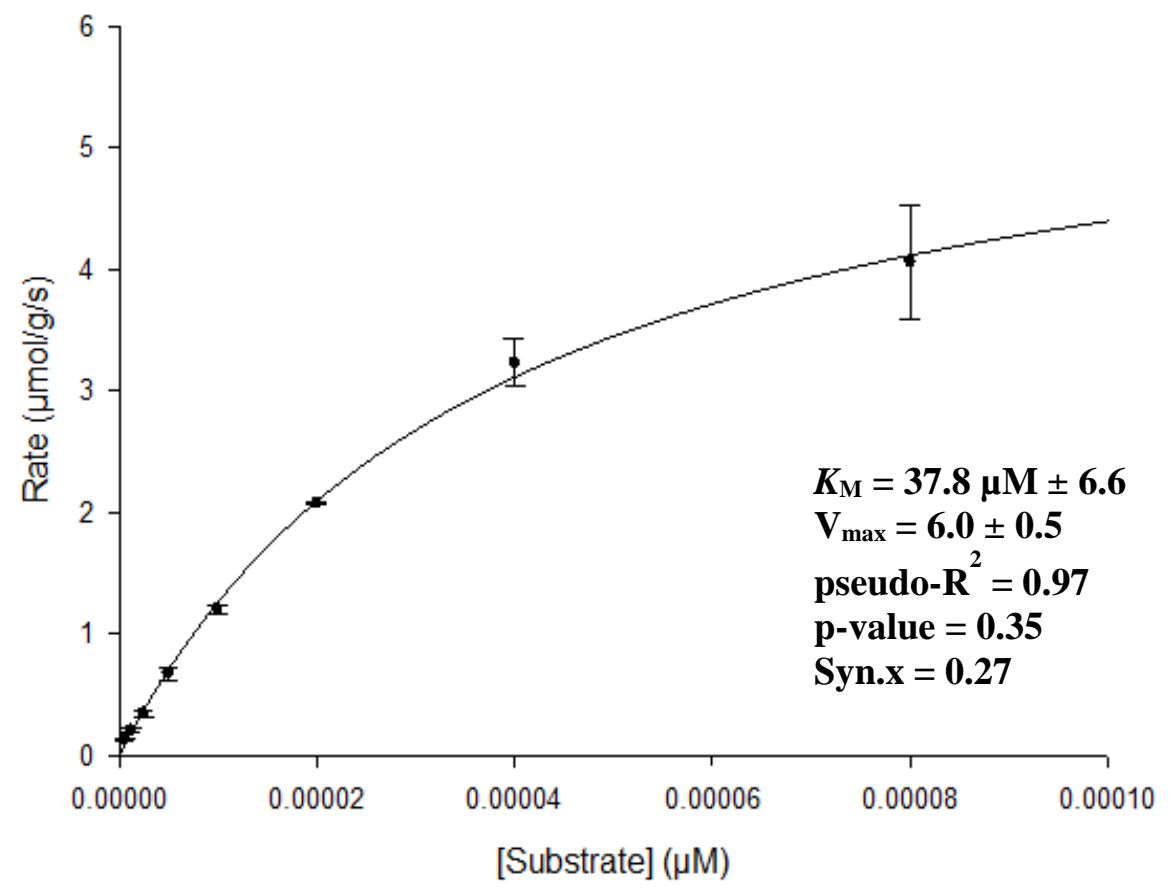

Figure 12: $h$ CatS velocity plot as a function of Z-Phe-Arg-AMC concentration adjusted in the MichaelisMenten equation.

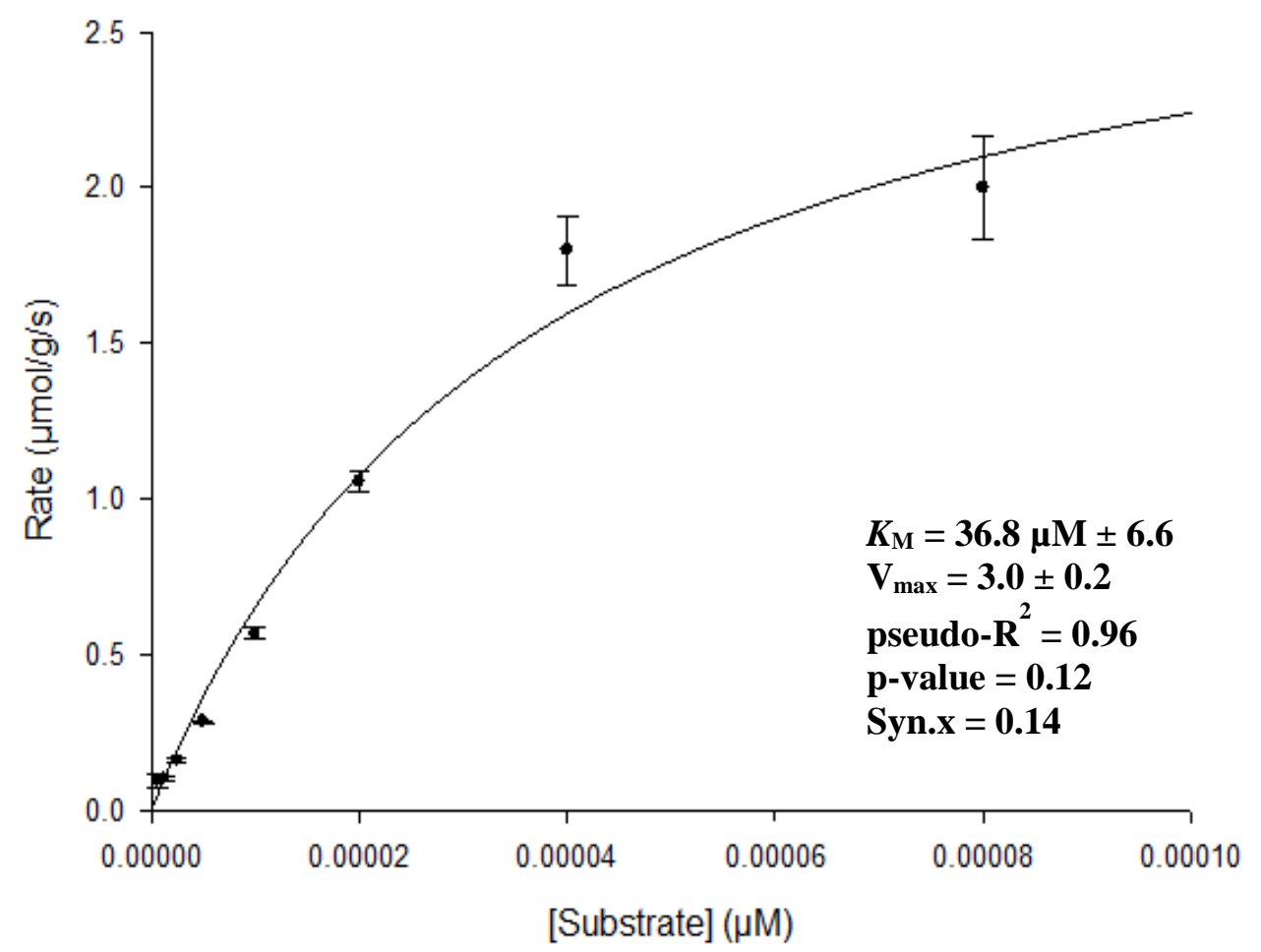


- $h$ CatK replicates:

Figure 13: $h$ CatK velocity plot as a function of Z-Leu-Arg-AMC concentration adjusted in the Michaelis-Menten equation.

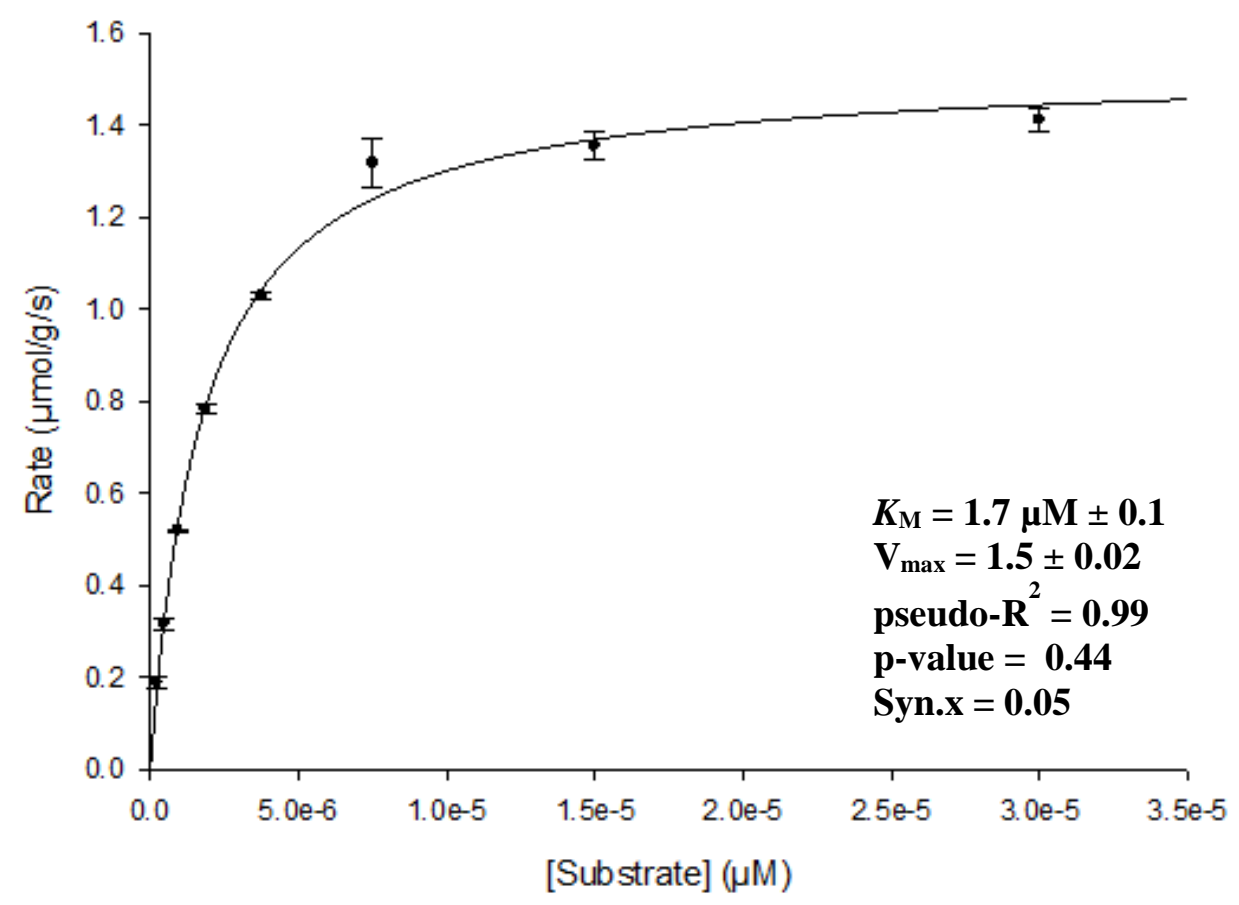

Figure 14: $h$ CatK velocity plot as a function of Z-Leu-Arg-AMC concentration adjusted in the Michaelis-Menten equation.

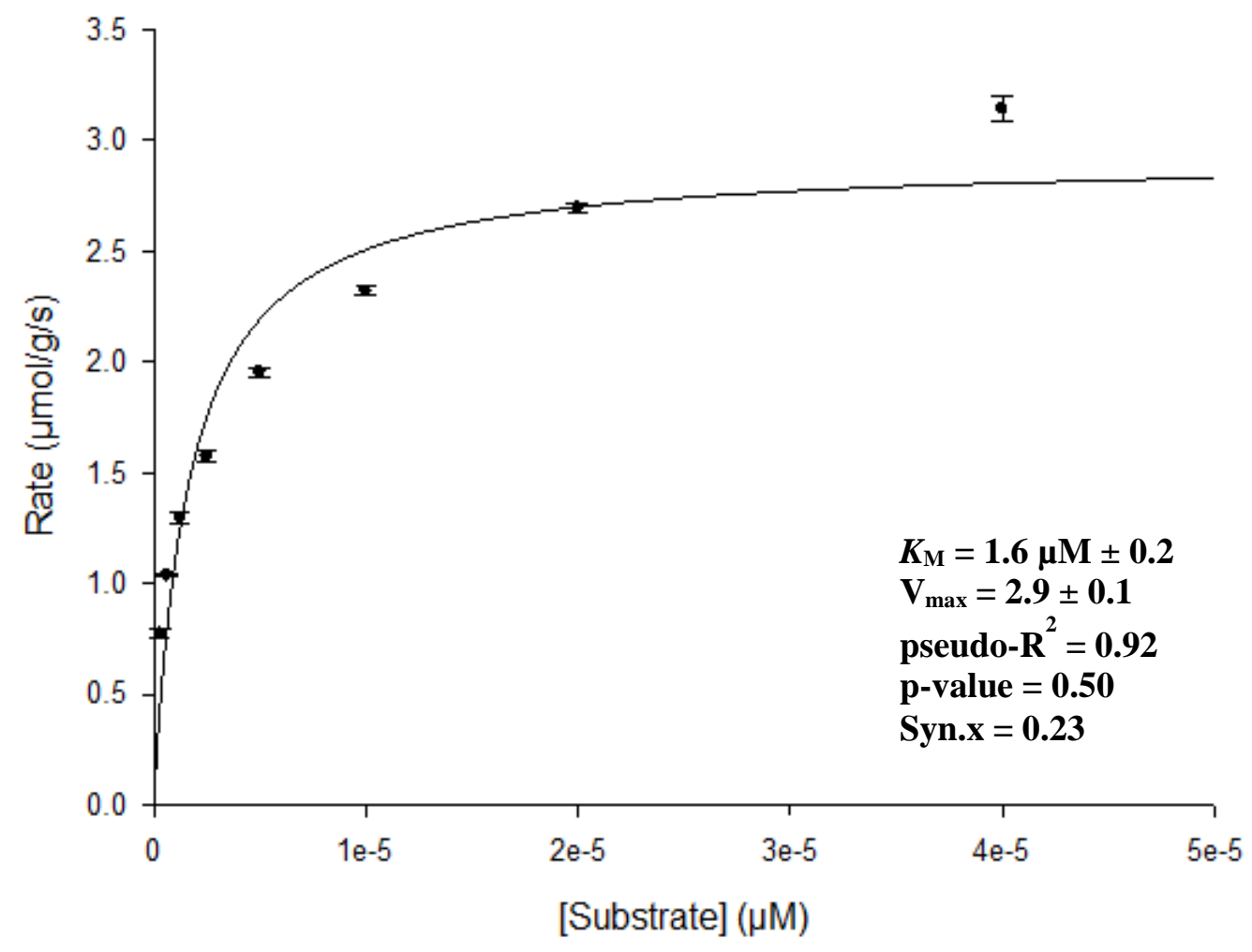




\section{APPENDIX B- SCATTER PLOTS BETWEEN THE FIVE CPS}

- Scatter plot of $\mathrm{Cz}$ against $L m \mathrm{CPB}, h \mathrm{CatL}, h \mathrm{CatS}$, and $h \mathrm{CatK}$.

Figure 15: Scatter plot obtained when analyzed $\mathrm{Cz}$ with $L m \mathrm{CPB}$.

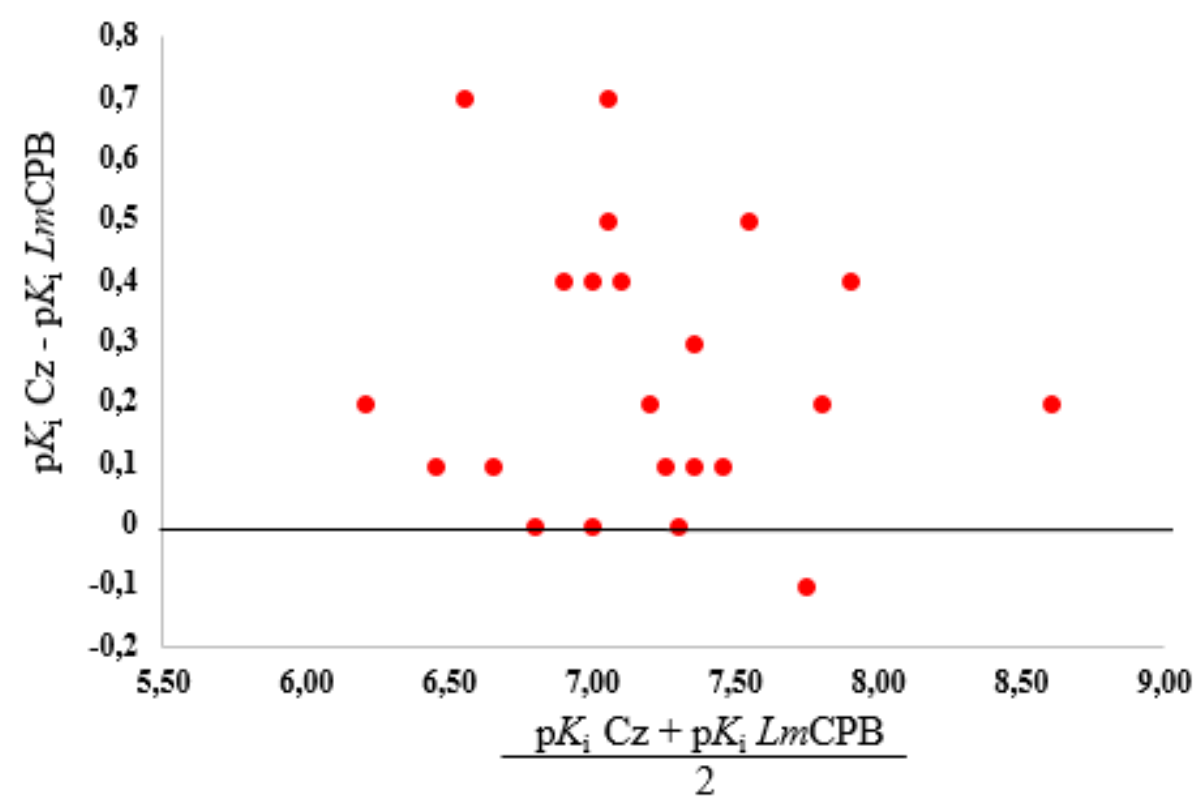

Figure 16: Scatter plot obtained when analyzed $\mathrm{Cz}$ with $h \mathrm{CatL}$.

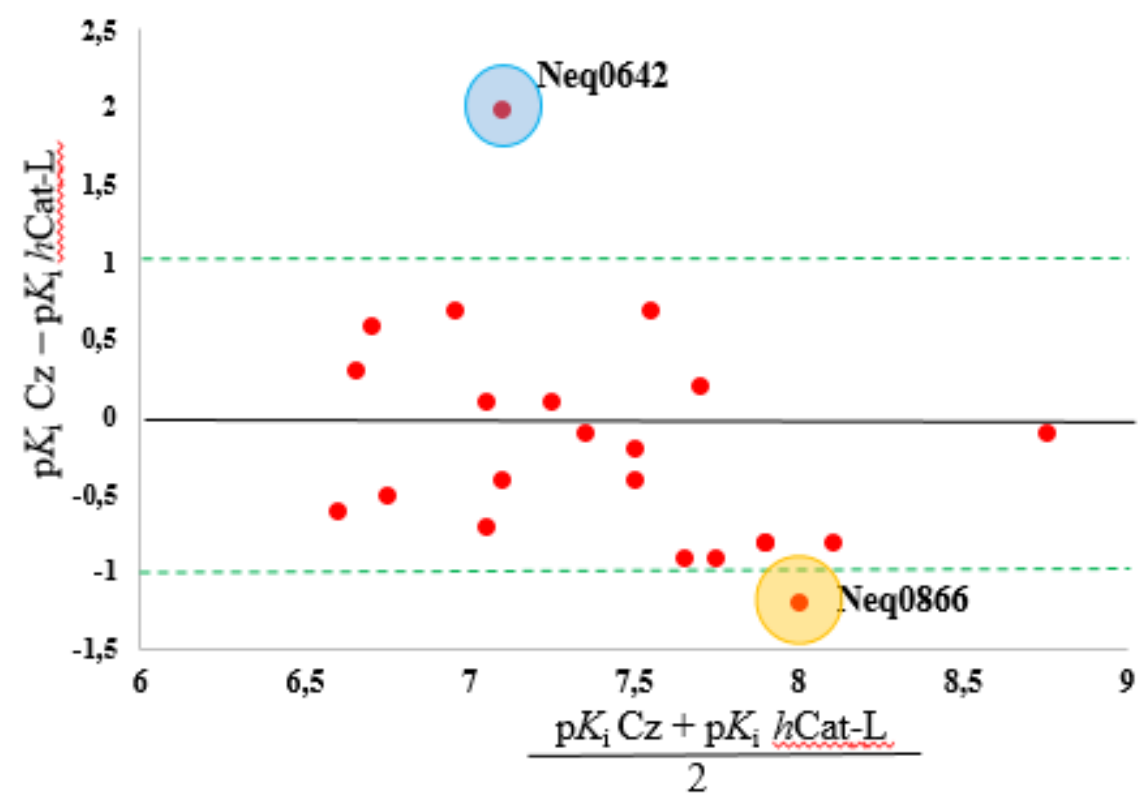


Figure 17: Scatter plot obtained when analyzed $\mathrm{Cz}$ with $h$ CatS.

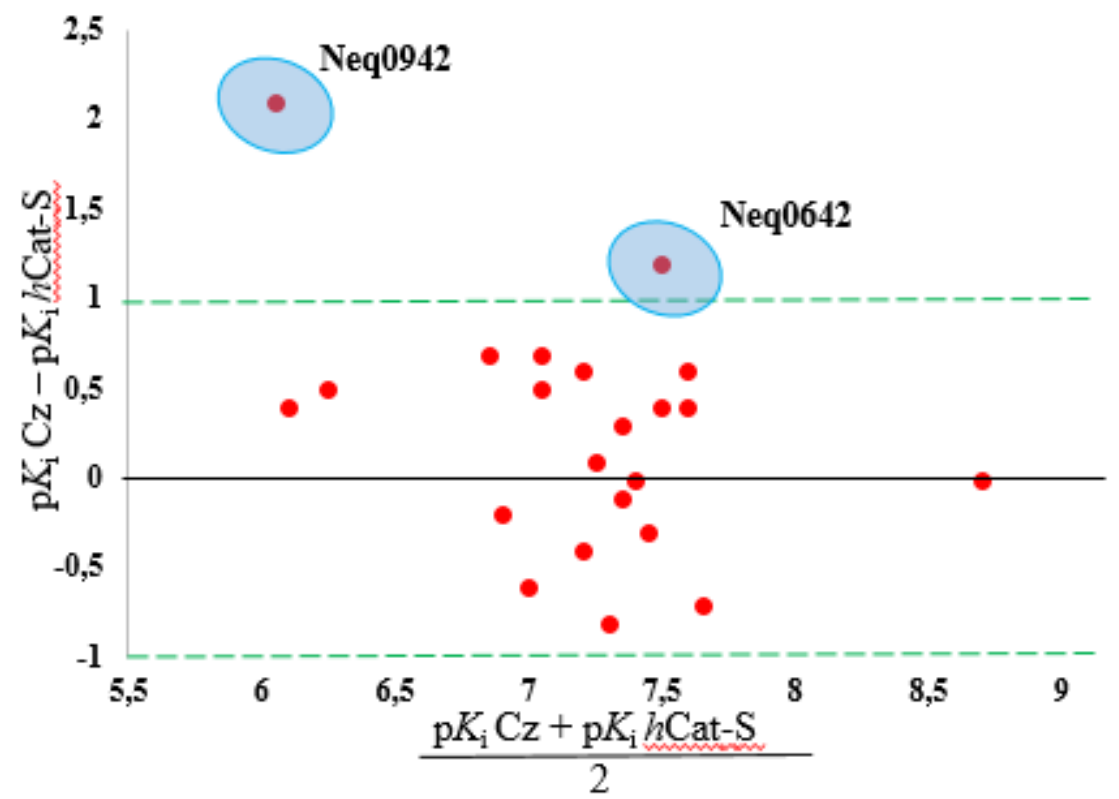

Figure 18: Scatter plot obtained when analyzed $\mathrm{Cz}$ with $h \mathrm{CatK}$.

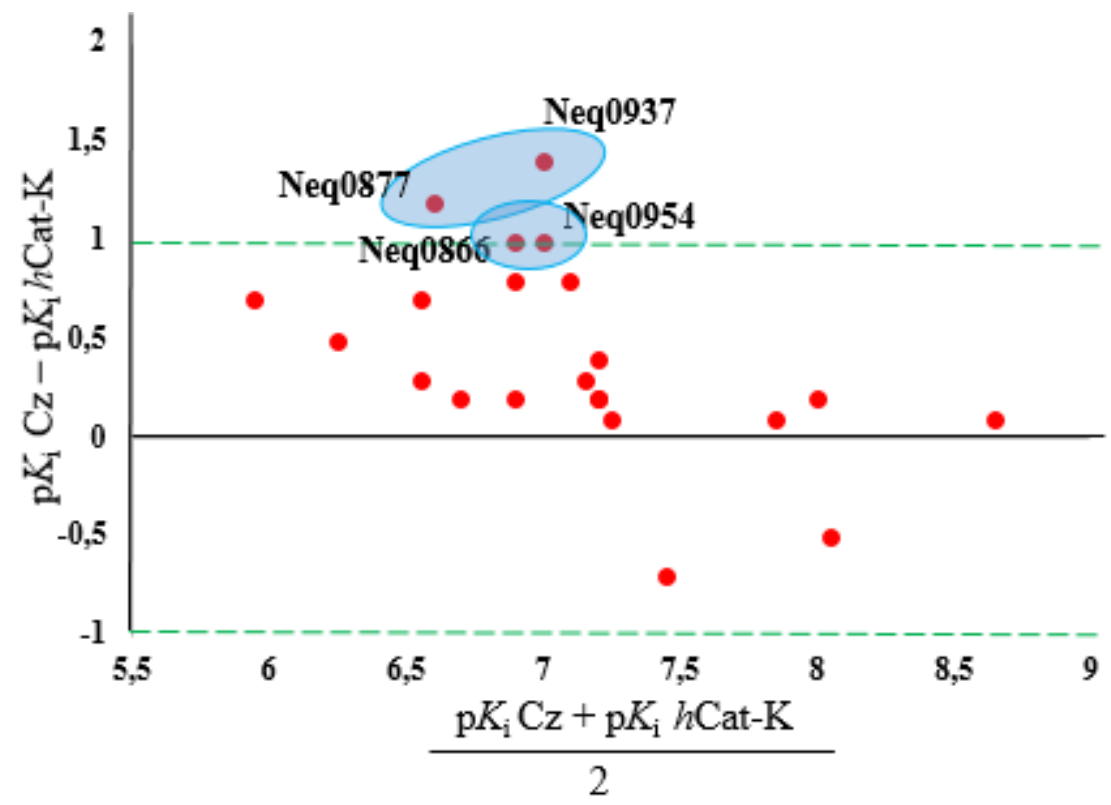


- Scatter plot of $L m C P B$ against $h$ CatS and $h$ CatK.

Figure 19: Scatter plot obtained when analyzed $L m C P B$ with $h$ CatS.

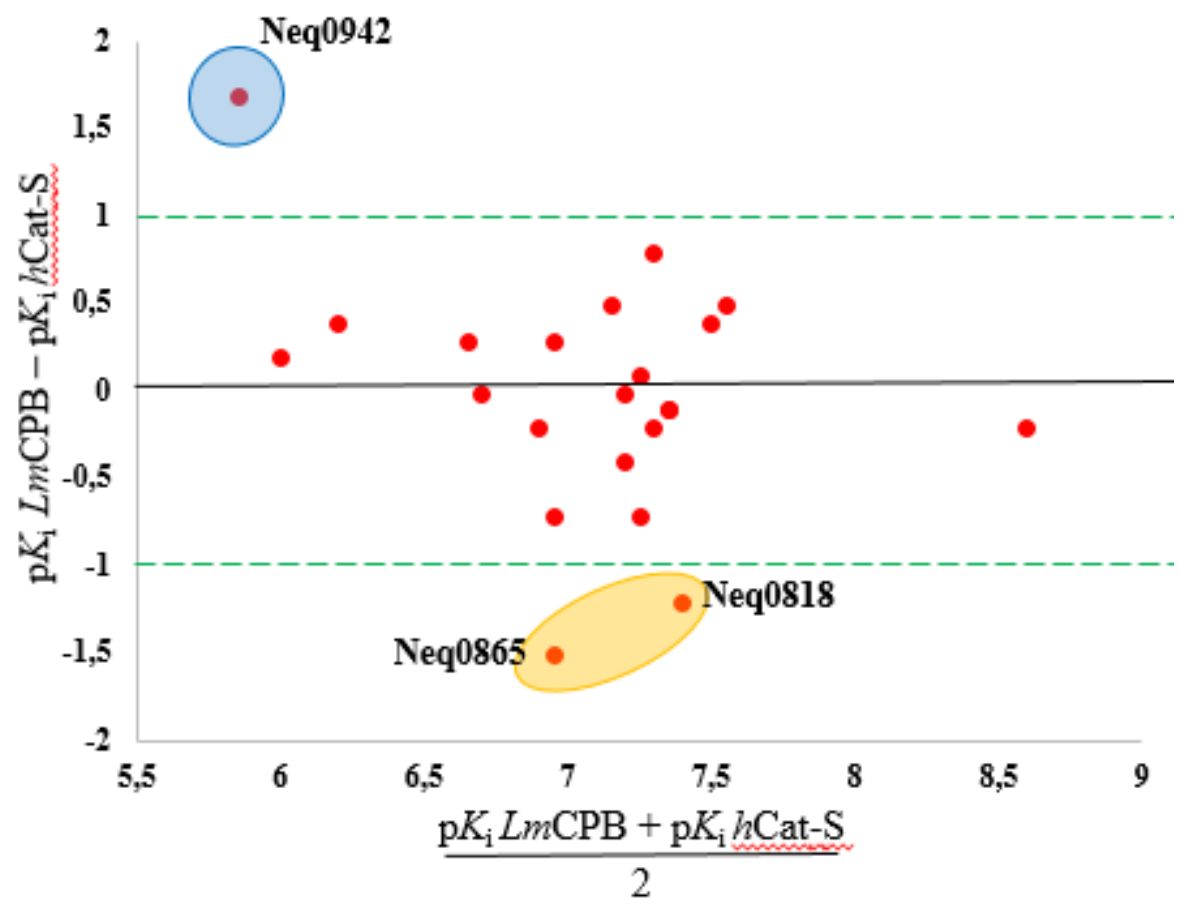

Figure 20: Scatter plot obtained when analyzed $L m C P B$ with $h$ CatK.

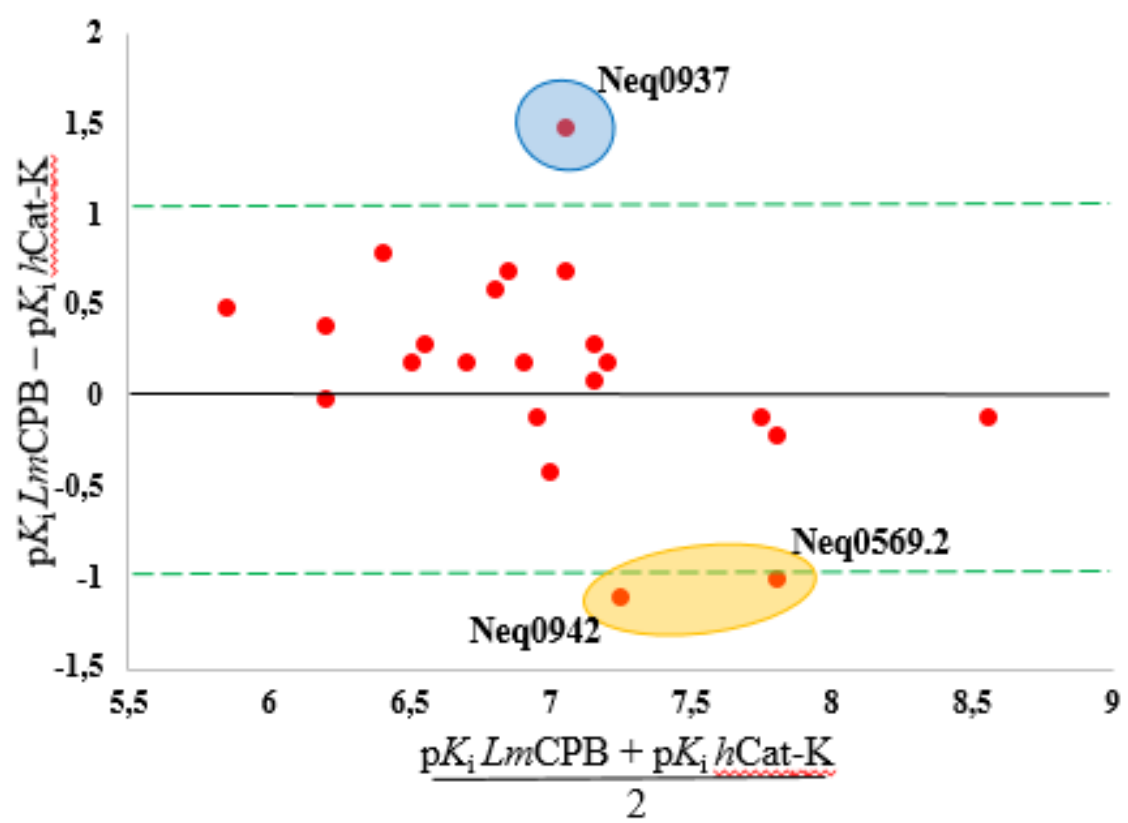


- Scatter plot of $h$ CatL against $h$ CatS and $h$ CatK.

Figure 21: Scatter plot obtained when analyzed $h$ CatL with $h$ CatS.

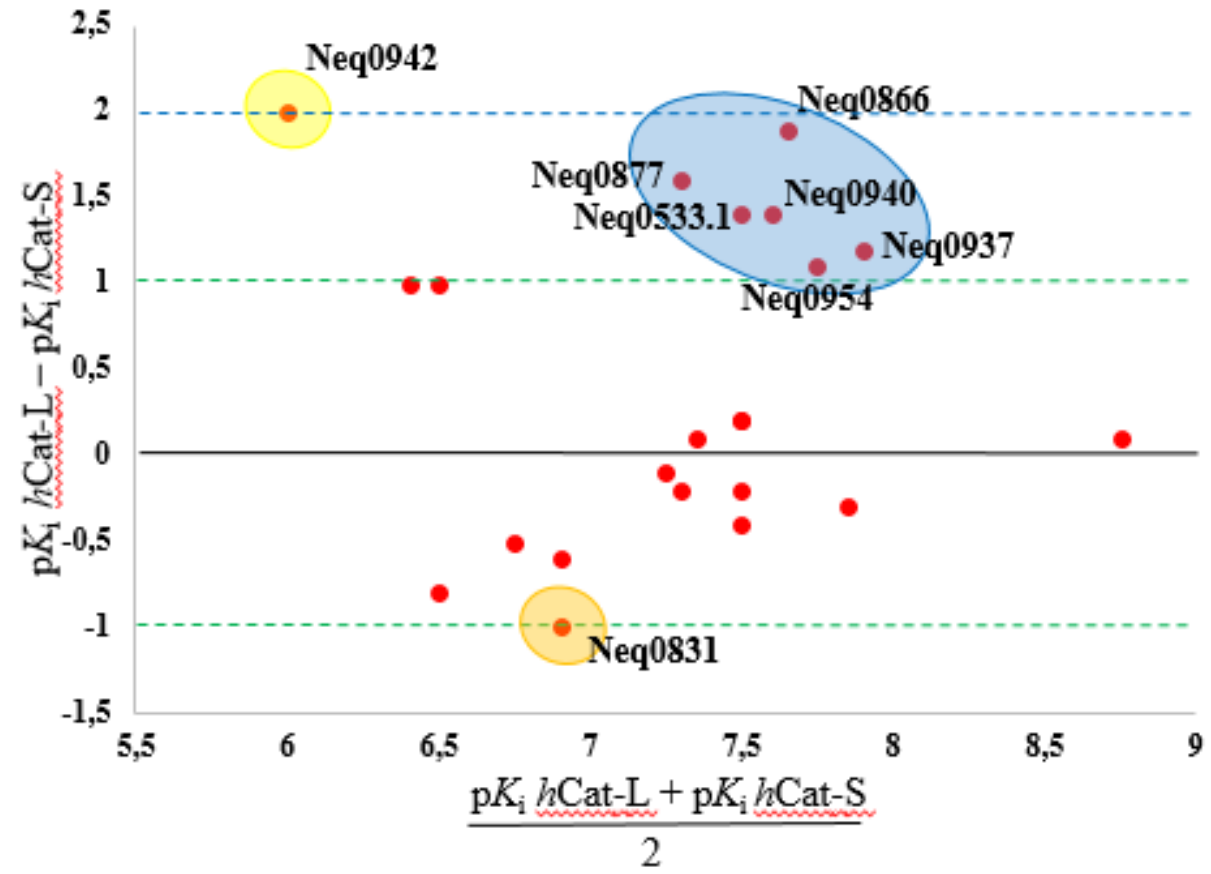

Figure 22: Scatter plot obtained when analyzed $h$ CatL with $h$ CatK.

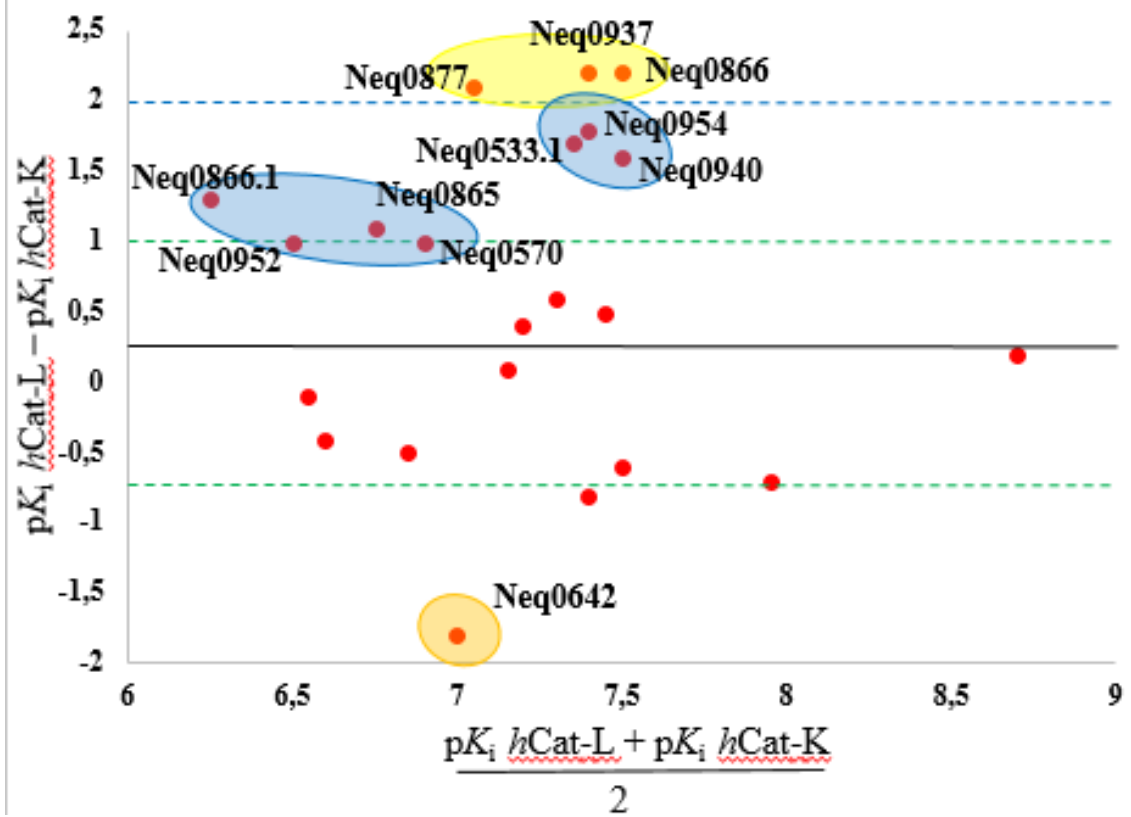


- Scatter plot $h$ CatS against $h$ CatK.

Figure 23: Scatter plot obtained when analyzed $h$ CatS with $h$ CatK.

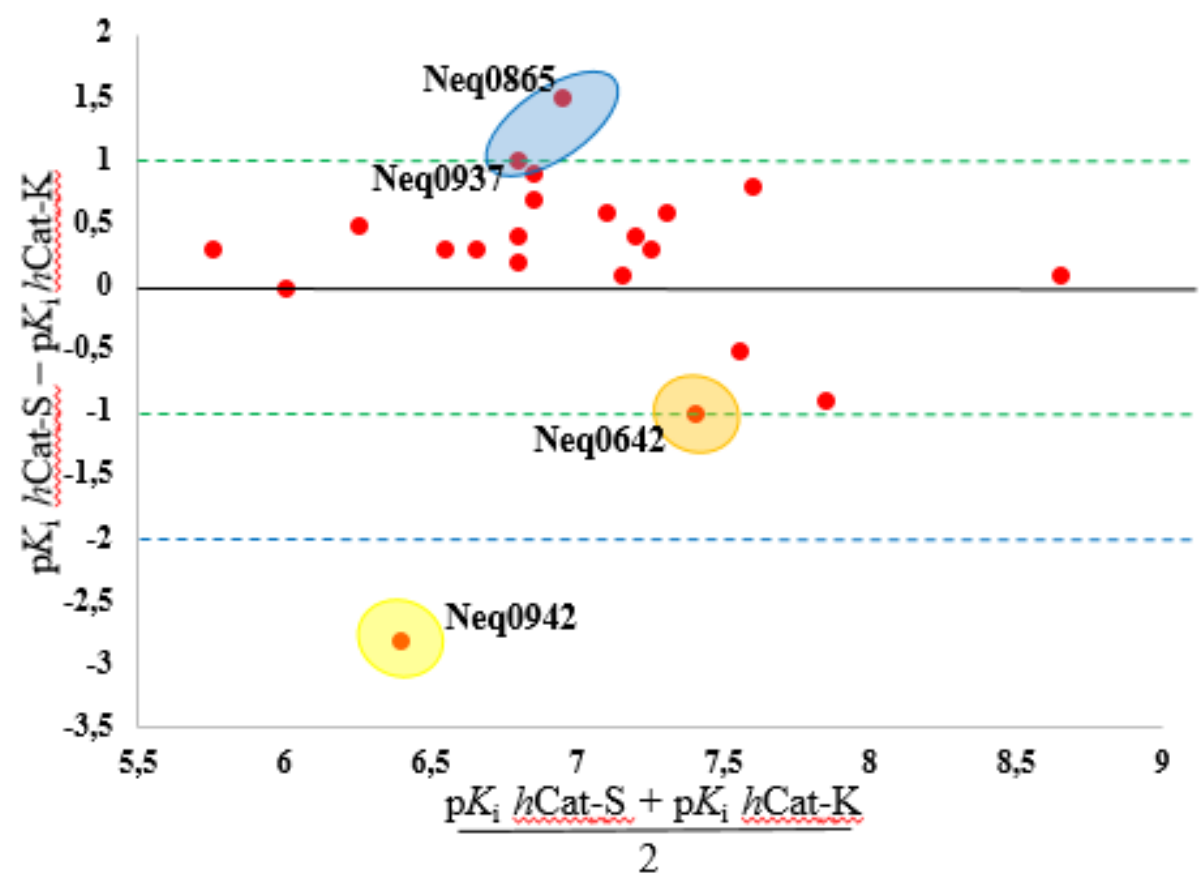




\section{APPENDIX C- THERMAL STABILITY STUDY OF CRUZAIN AGAINST FOURTEEN LIGANDS}

Figure 24: Cruzain unfolding peak when incubated with Neq0533.1 obtained after the correction of the blank (buffer - buffer + ligand). The solution was heated from 0 to $90{ }^{\circ} \mathrm{C}$ in acetate buffer $\mathrm{pH}=5.5,3$ atm and a rate of $2{ }^{\circ} \mathrm{C} / \mathrm{min}$. The ligand concentration was $120 \mu \mathrm{M}$.

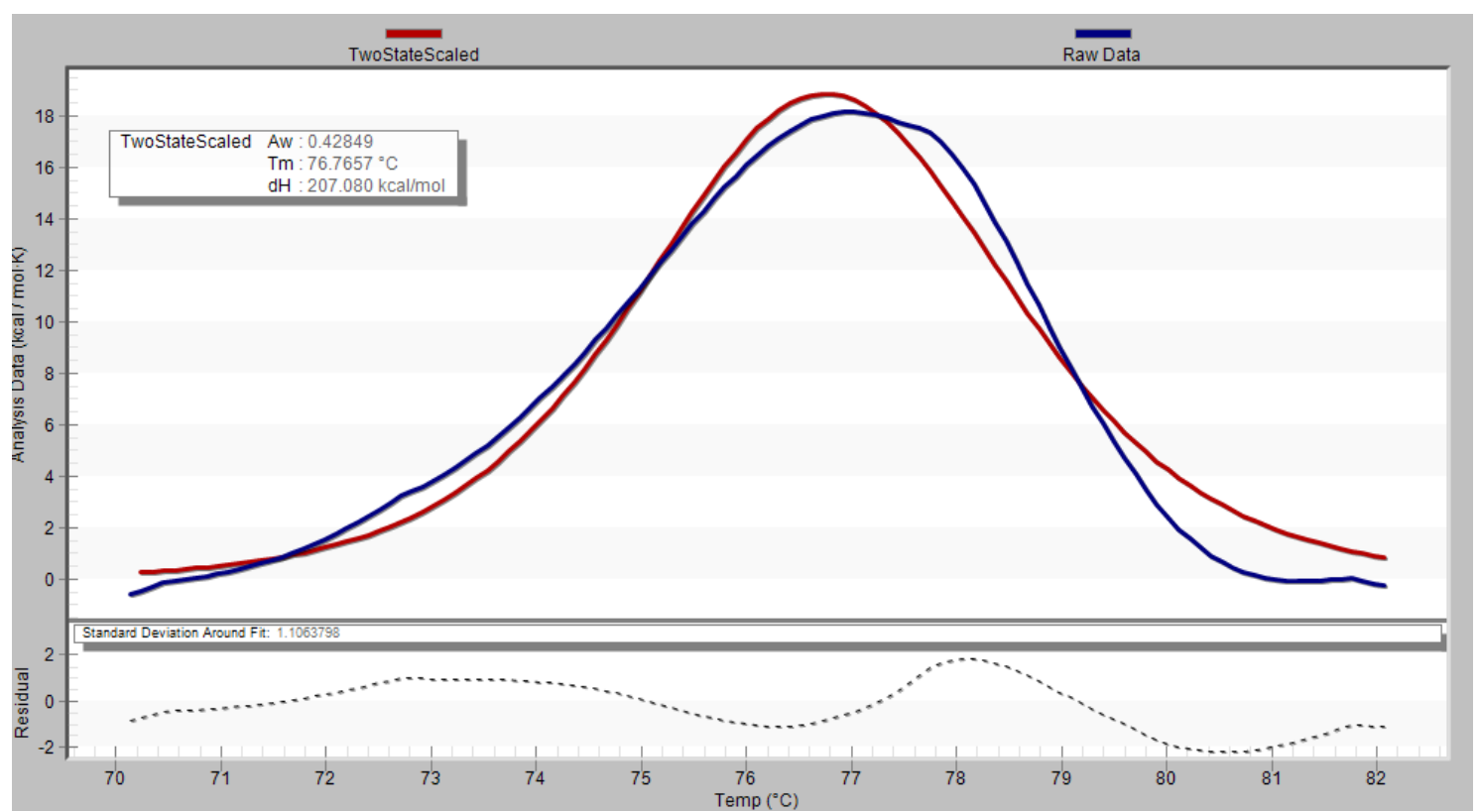

Figure 25: Cruzain unfolding peak when incubated with Neq0570 obtained after the correction of the blank (buffer-buffer + ligand). The solution was heated from 0 to $90{ }^{\circ} \mathrm{C}$ in acetate buffer $\mathrm{pH}=5.5,3$ atm and a rate of $2{ }^{\circ} \mathrm{C} / \mathrm{min}$. The ligand concentration was $120 \mu \mathrm{M}$.

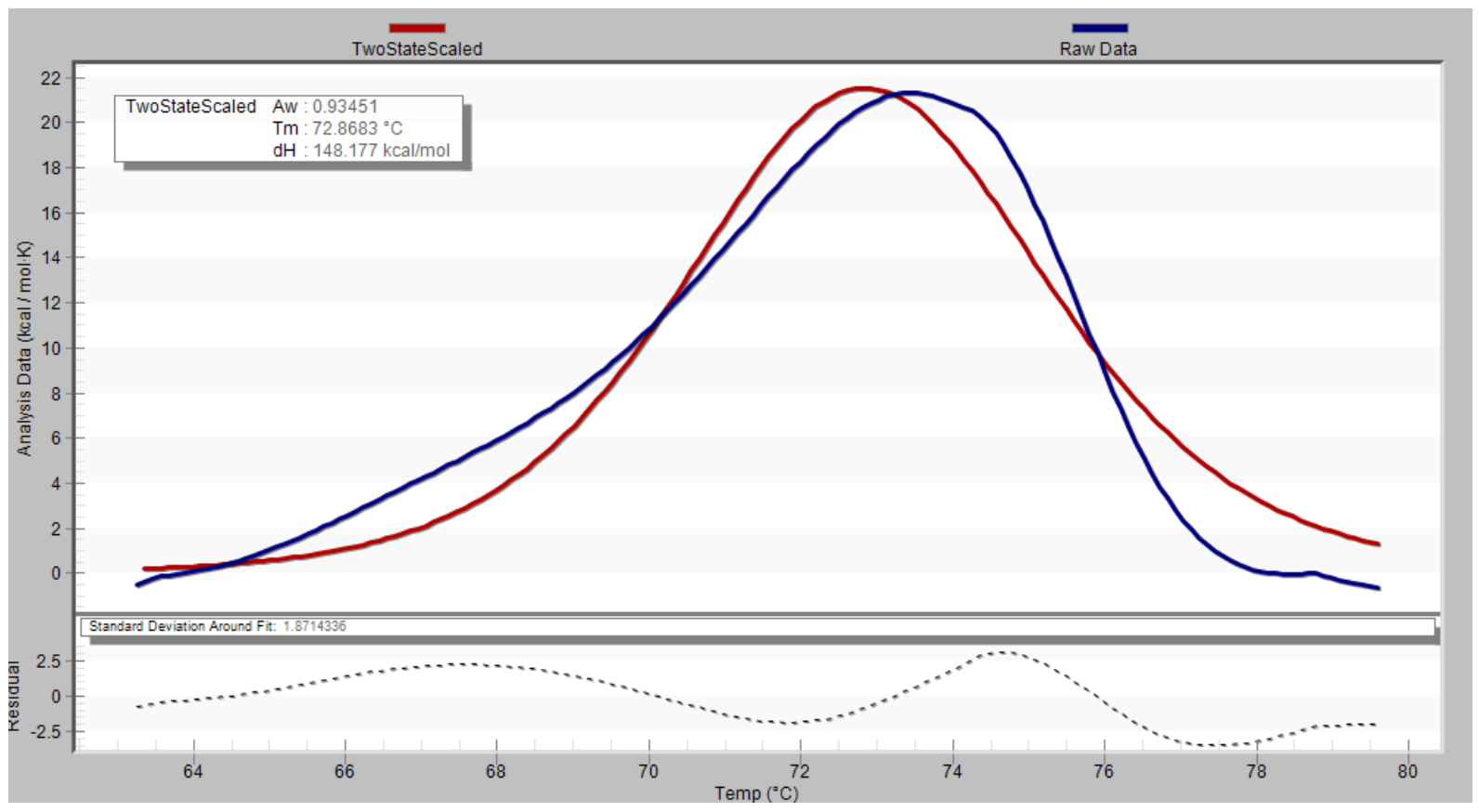


Figure 26: Cruzain unfolding peak when incubated with Neq0635.1 obtained after the correction of the blank (buffer-buffer + ligand). The solution was heated from 0 to $90{ }^{\circ} \mathrm{C}$ in acetate buffer $\mathrm{pH}=5.5,3$ atm and a rate of $2{ }^{\circ} \mathrm{C} / \mathrm{min}$. The ligand concentration was $120 \mu \mathrm{M}$.

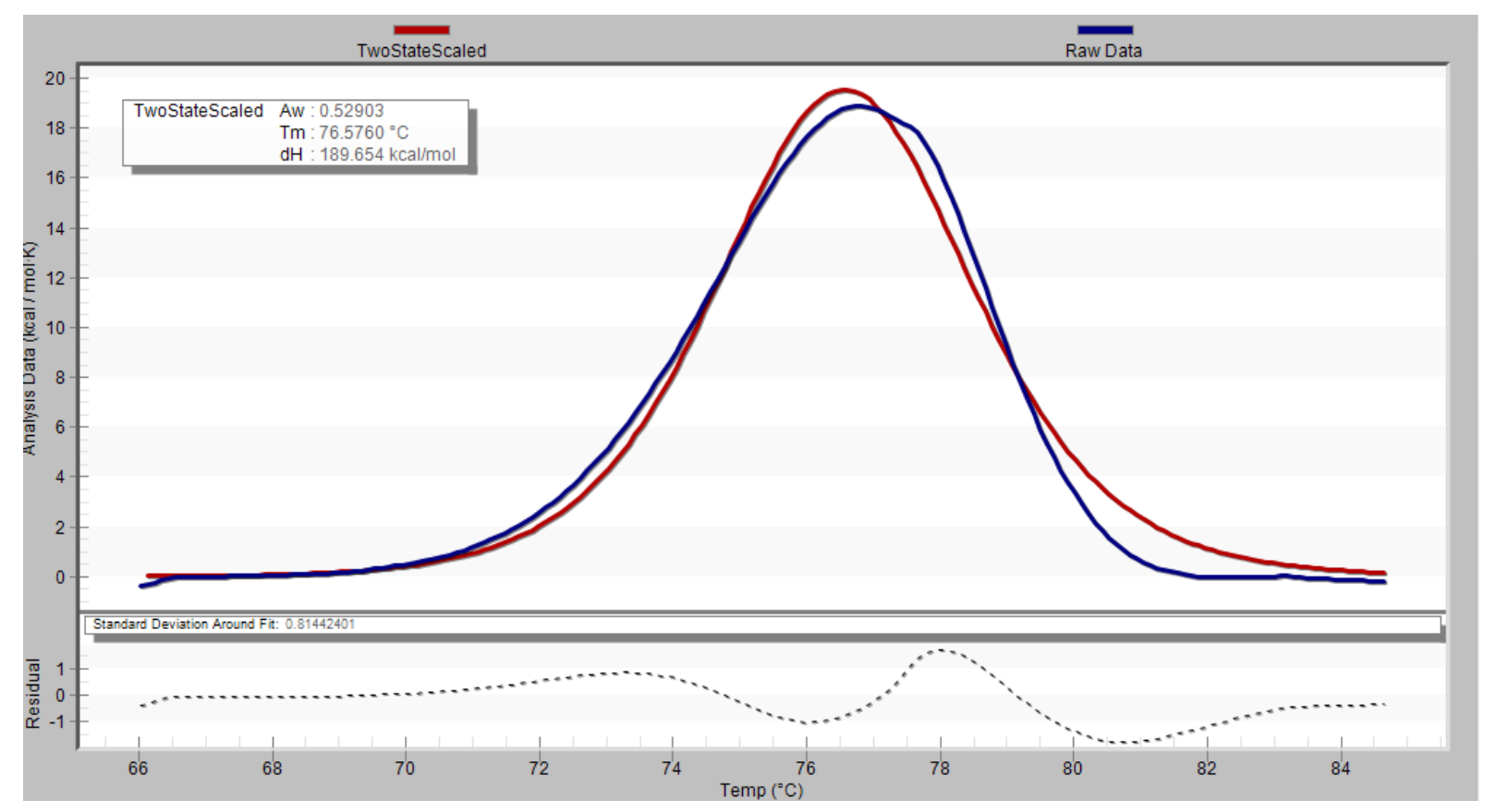

Figure 27: Cruzain unfolding peak when incubated with Neq0643.1 obtained after the correction of the blank (buffer-buffer + ligand). The solution was heated from 0 to $90{ }^{\circ} \mathrm{C}$ in acetate buffer $\mathrm{pH}=5.5,3$ atm and a rate of $2{ }^{\circ} \mathrm{C} / \mathrm{min}$. The ligand concentration was $120 \mu \mathrm{M}$.

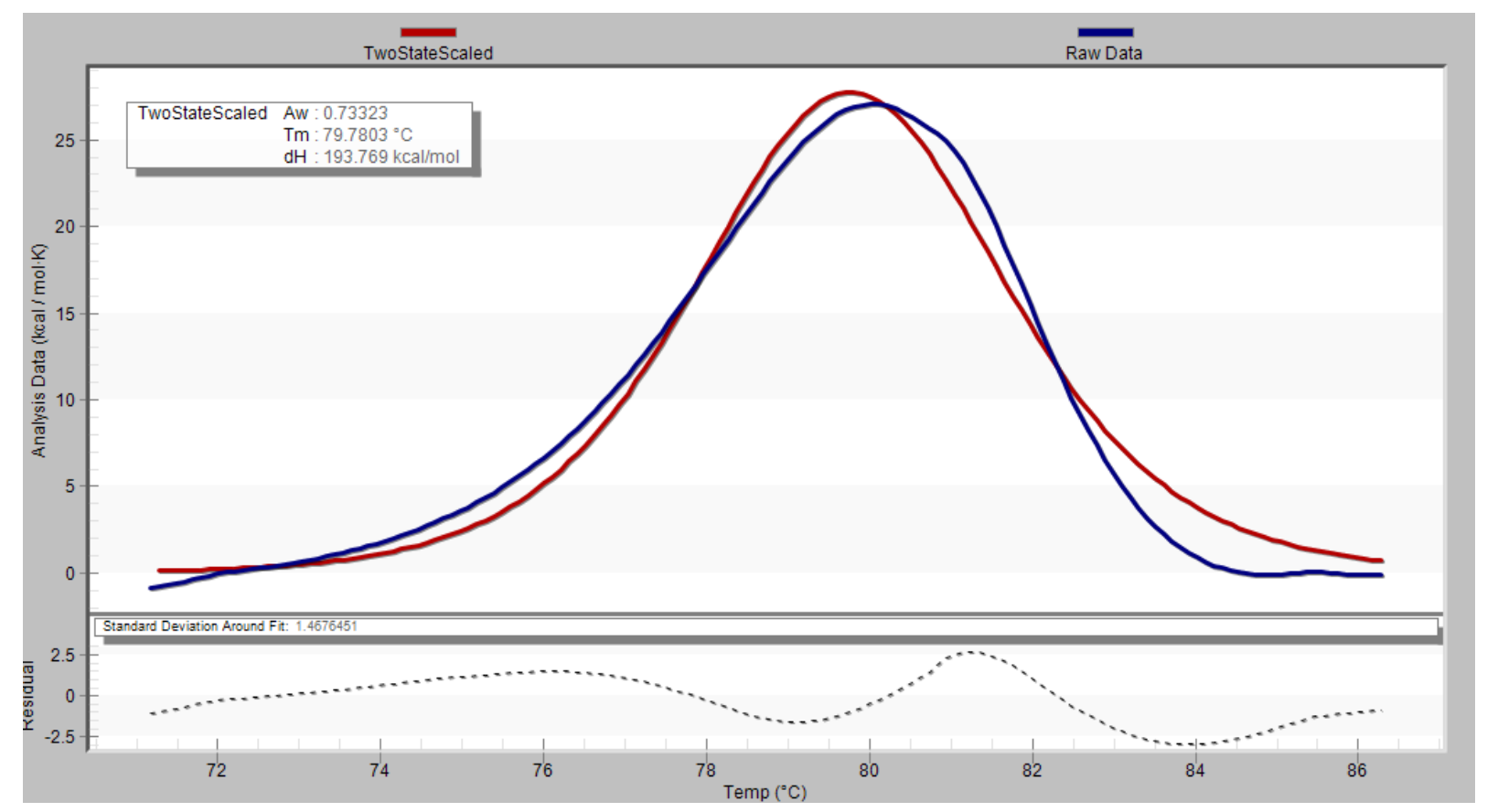


Figure 28: Cruzain unfolding peak when incubated with Neq0818 obtained after the correction of the blank (buffer-buffer + ligand). The solution was heated from 0 to $90{ }^{\circ} \mathrm{C}$ in acetate buffer $\mathrm{pH}=5.5,3$ atm and a rate of $2{ }^{\circ} \mathrm{C} / \mathrm{min}$. The ligand concentration was $120 \mu \mathrm{M}$.

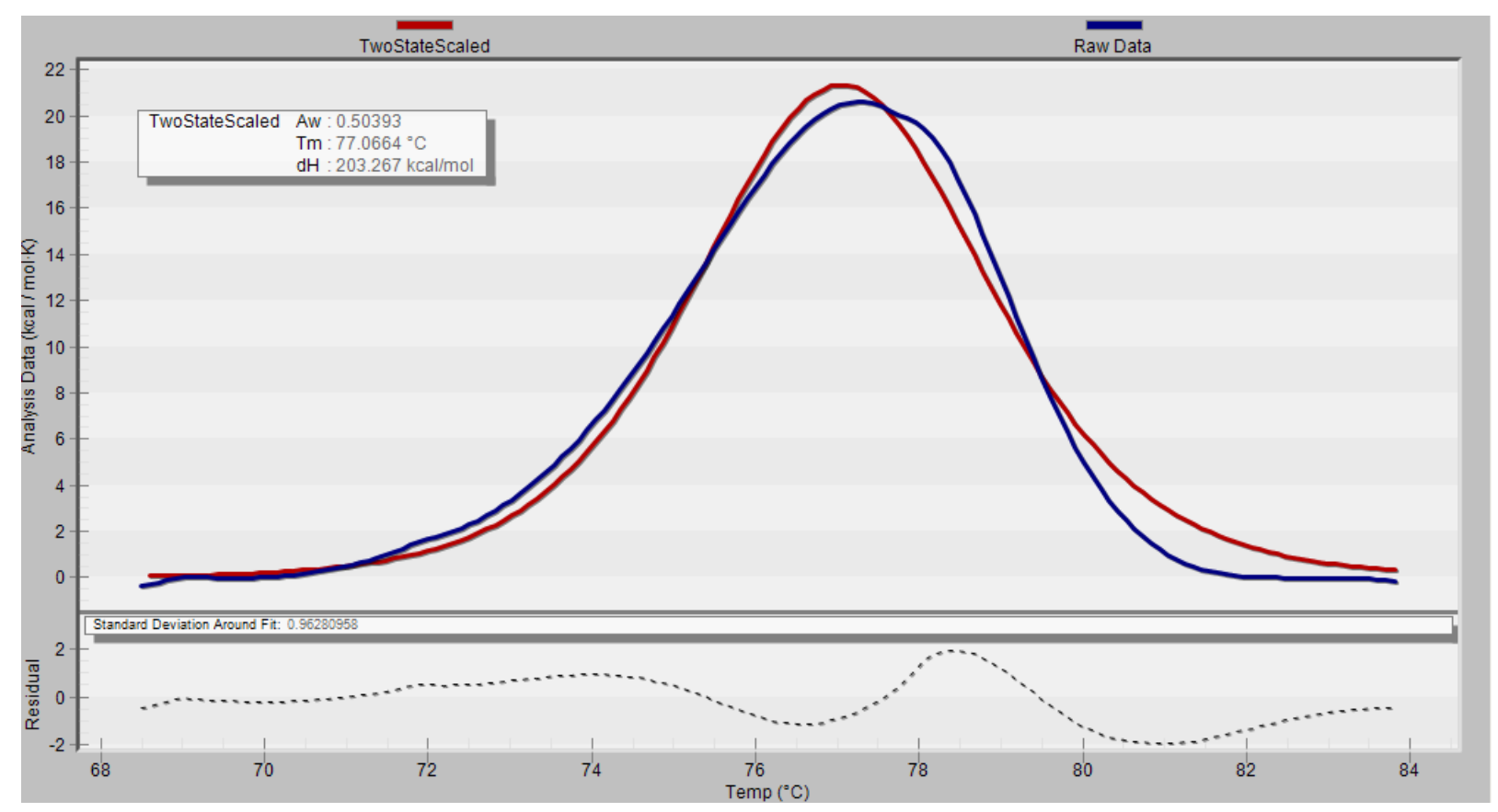

Figure 29: Cruzain unfolding peak when incubated with Neq0865 obtained after the correction of the blank (buffer-buffer + ligand). The solution was heated from 0 to $90{ }^{\circ} \mathrm{C}$ in acetate buffer $\mathrm{pH}=5.5,3$ atm and a rate of $2{ }^{\circ} \mathrm{C} / \mathrm{min}$. The ligand concentration was $120 \mu \mathrm{M}$.

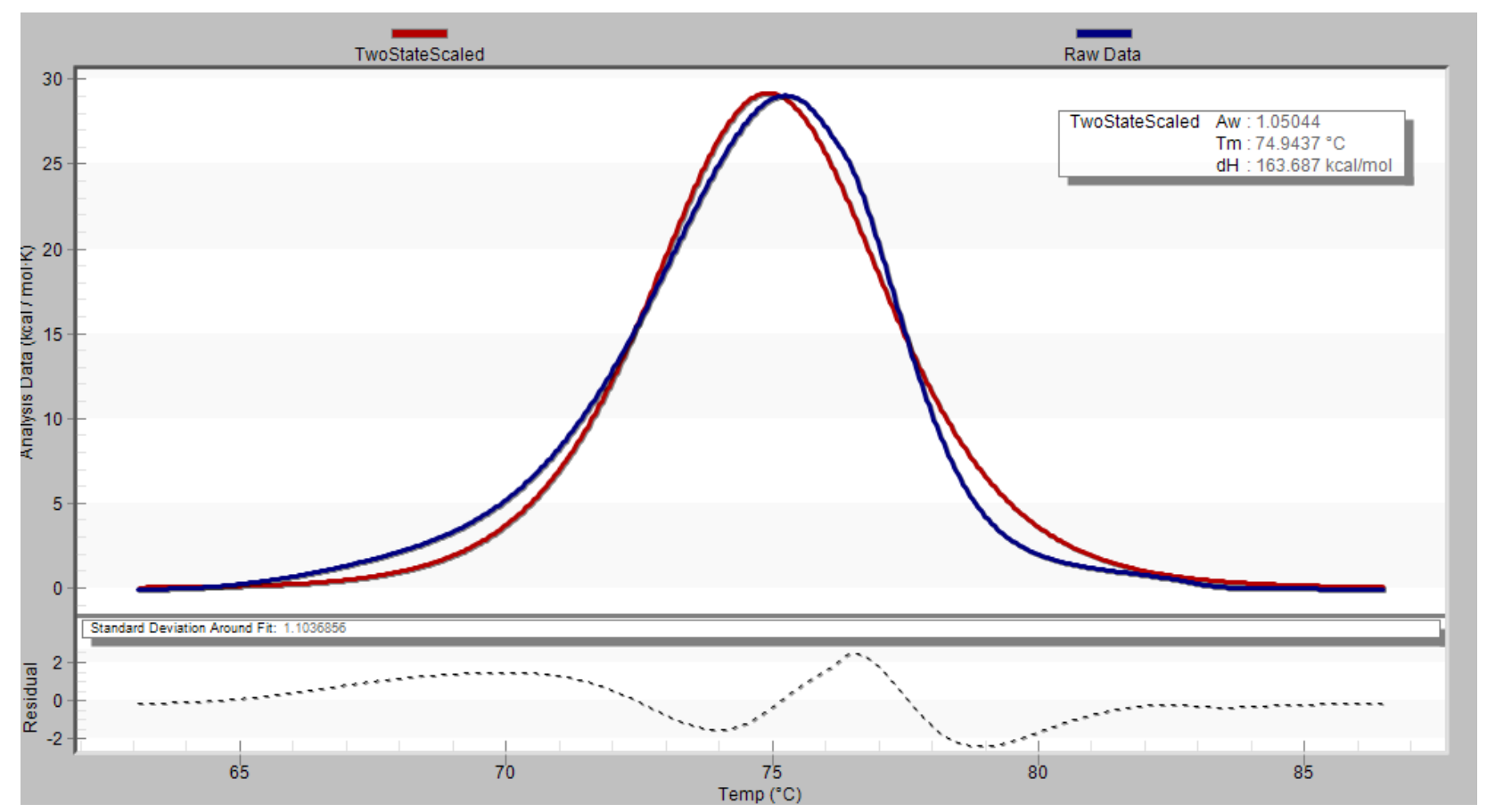


Figure 30: Cruzain unfolding peak when incubated with Neq0866 obtained after the correction of the blank (buffer-buffer + ligand). The solution was heated from 0 to $90{ }^{\circ} \mathrm{C}$ in acetate buffer $\mathrm{pH}=5.5,3$ atm and a rate of $2{ }^{\circ} \mathrm{C} / \mathrm{min}$. The ligand concentration was $120 \mu \mathrm{M}$.

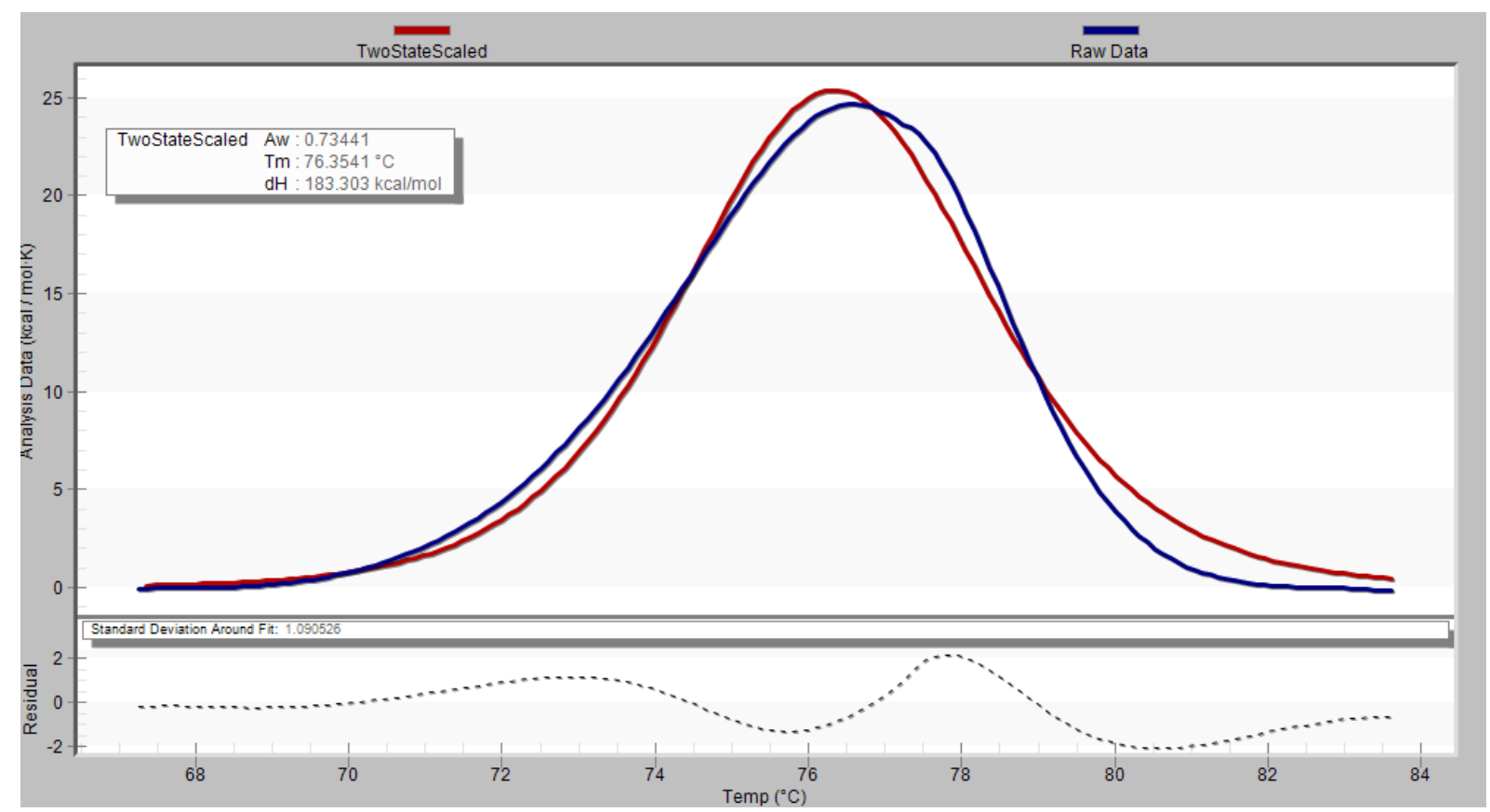

Figure 31: Cruzain unfolding peak when incubated with Neq0922 obtained after the correction of the blank (buffer-buffer + ligand). The solution was heated from 0 to $90{ }^{\circ} \mathrm{C}$ in acetate buffer $\mathrm{pH}=5.5,3$ atm and a rate of $2{ }^{\circ} \mathrm{C} / \mathrm{min}$. The ligand concentration was $120 \mu \mathrm{M}$.

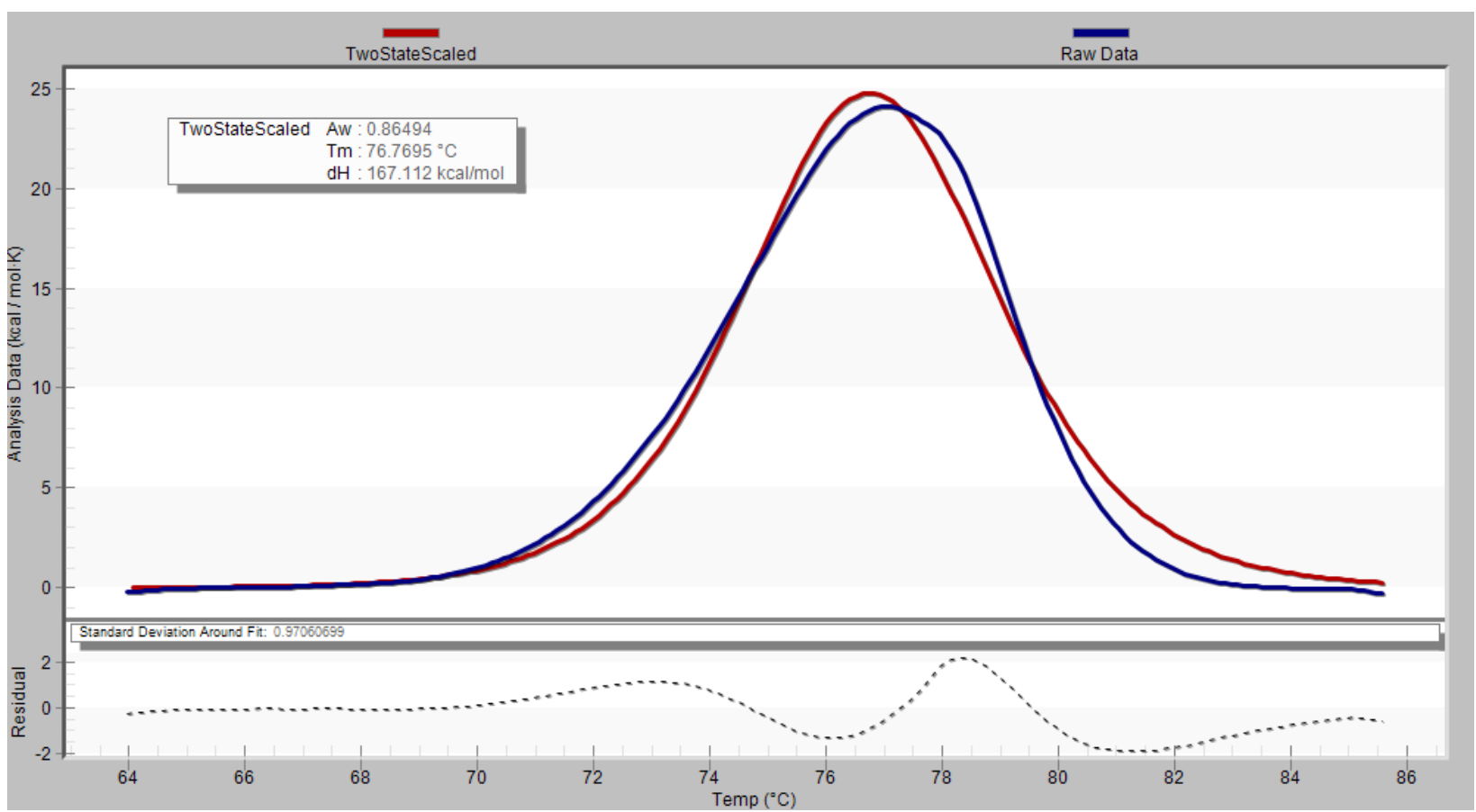


Figure 32: Cruzain unfolding peak when incubated with Neq0925 obtained after the correction of the blank (buffer-buffer + ligand). The solution was heated from 0 to $90{ }^{\circ} \mathrm{C}$ in acetate buffer $\mathrm{pH}=5.5,3$ atm and a rate of $2{ }^{\circ} \mathrm{C} / \mathrm{min}$. The ligand concentration was $120 \mu \mathrm{M}$.

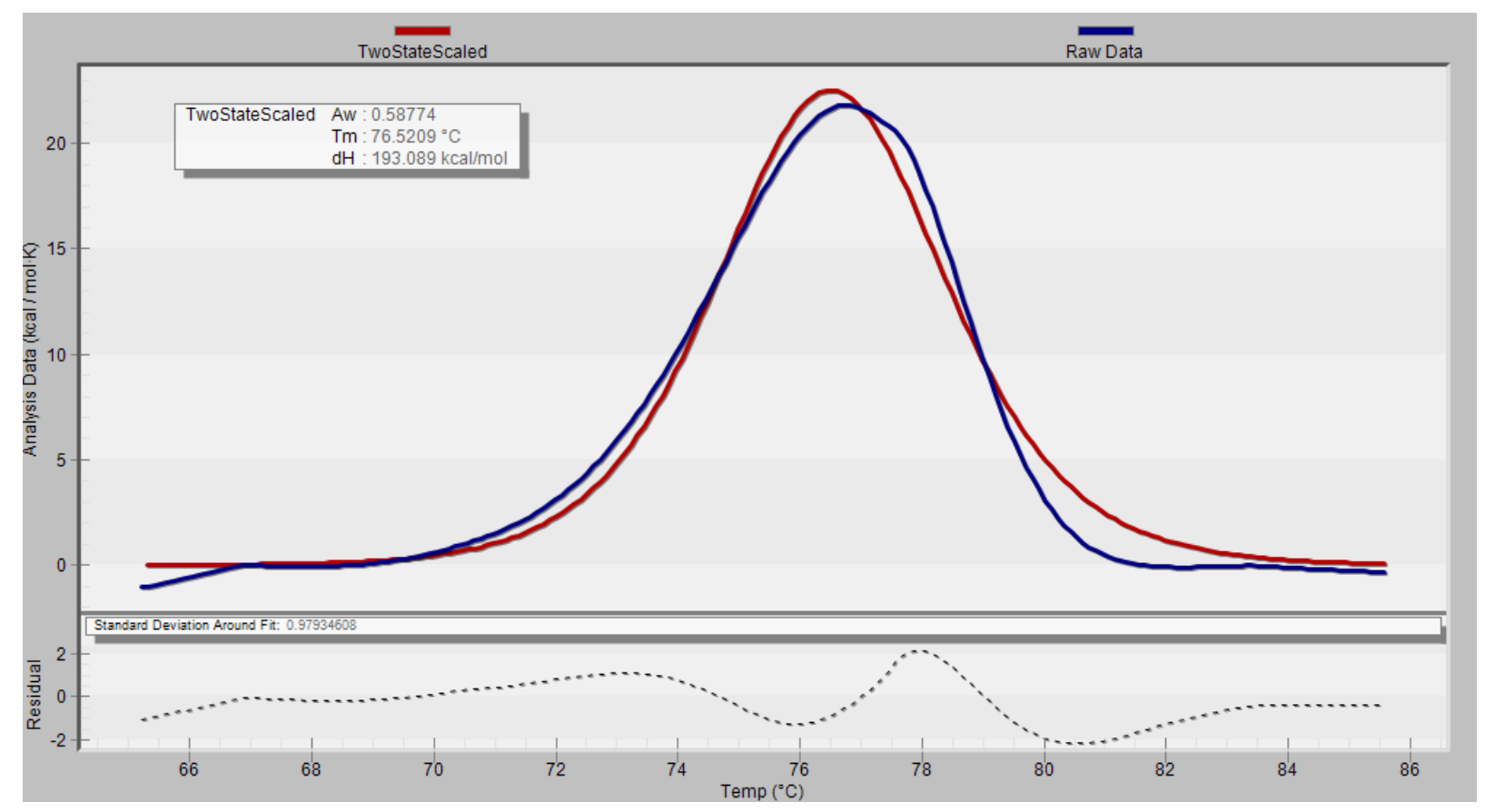

Figure 33: Cruzain unfolding peak when incubated with Neq0937 obtained after the correction of the blank (buffer-buffer + ligand). The solution was heated from 0 to $90{ }^{\circ} \mathrm{C}$ in acetate buffer $\mathrm{pH}=5.5,3$ atm and a rate of $2{ }^{\circ} \mathrm{C} / \mathrm{min}$. The ligand concentration was $120 \mu \mathrm{M}$.

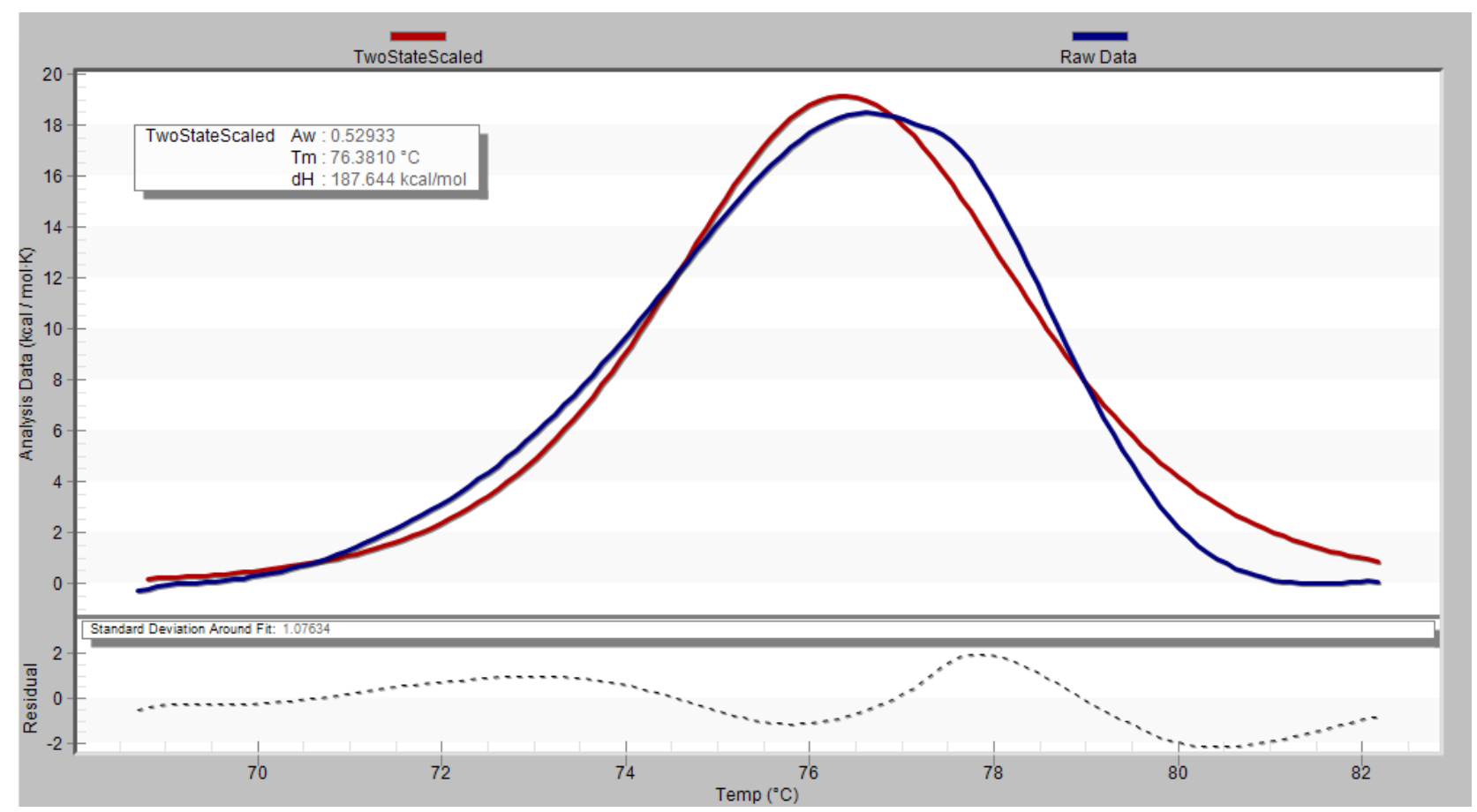


Figure 34: Cruzain unfolding peak when incubated with Neq0940 obtained after the correction of the blank (buffer-buffer + ligand). The solution was heated from 0 to $90{ }^{\circ} \mathrm{C}$ in acetate buffer $\mathrm{pH}=5.5,3$ atm and a rate of $2{ }^{\circ} \mathrm{C} / \mathrm{min}$. The ligand concentration was $120 \mu \mathrm{M}$.

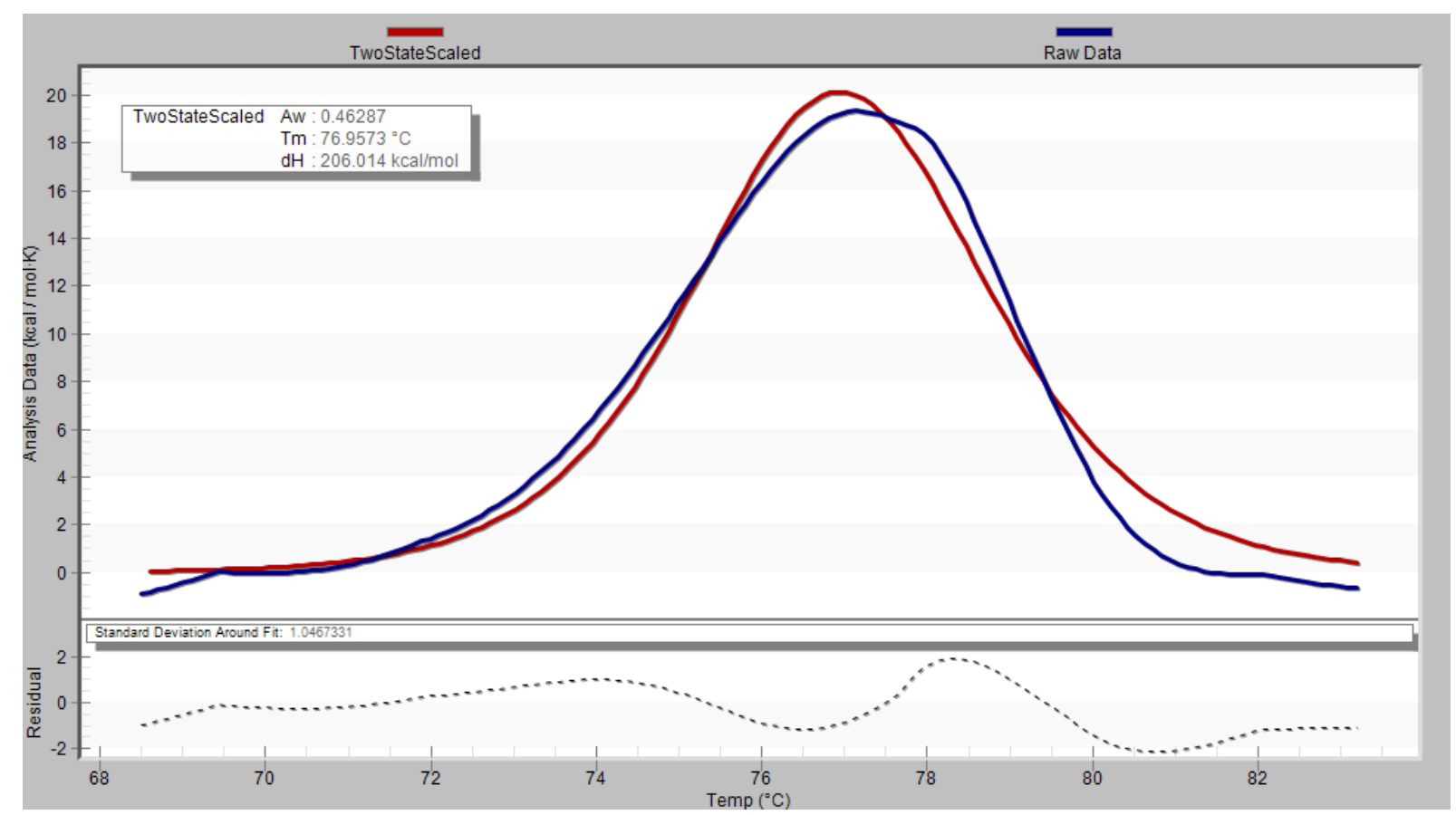

Figure 35: Cruzain unfolding peak when incubated with Neq0942 obtained after the correction of the blank (buffer-buffer + ligand). The solution was heated from 0 to $90{ }^{\circ} \mathrm{C}$ in acetate buffer $\mathrm{pH}=5.5,3$ atm and a rate of $2{ }^{\circ} \mathrm{C} / \mathrm{min}$. The ligand concentration was $120 \mu \mathrm{M}$.

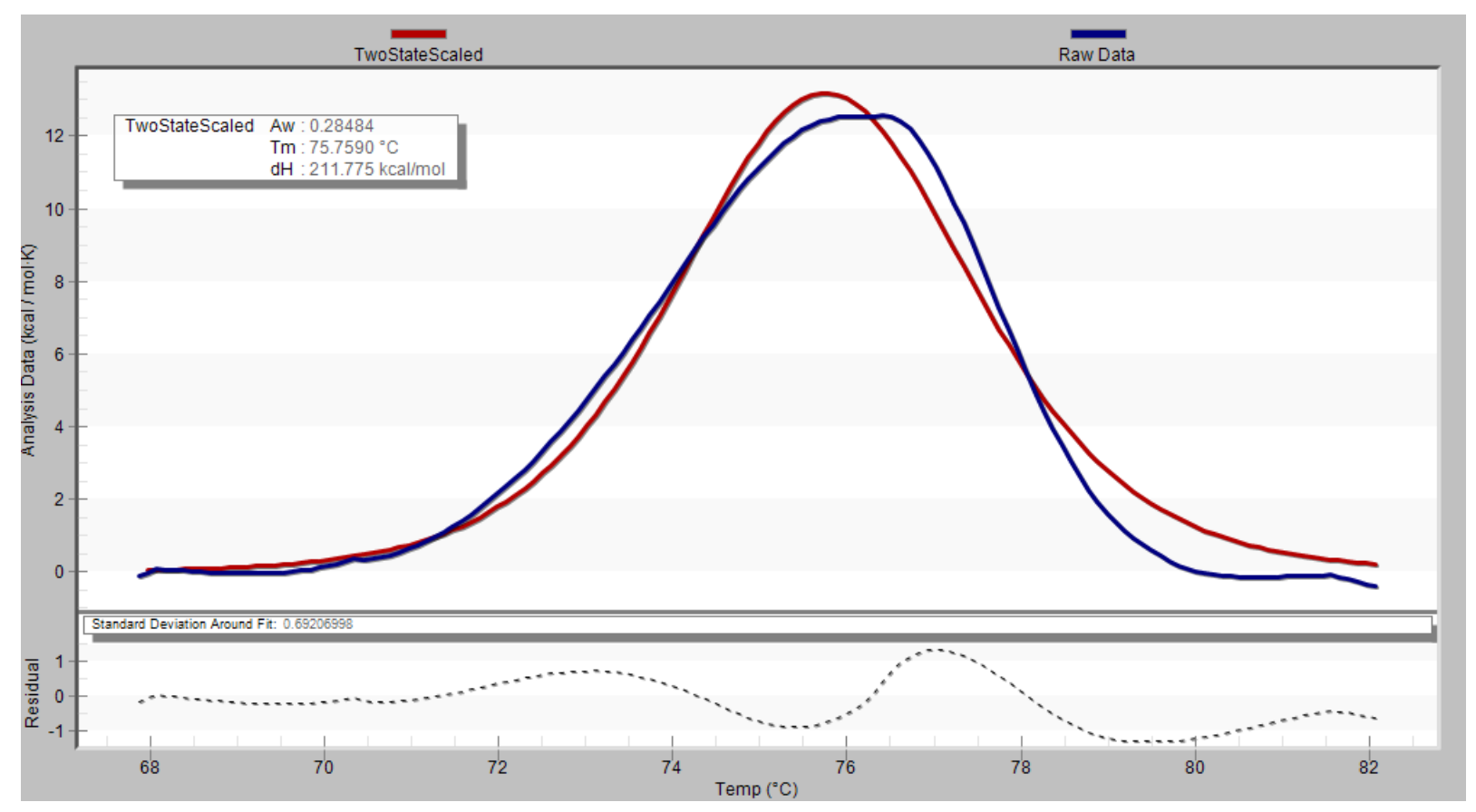


Figure 36: Cruzain unfolding peak when incubated with Neq0954 obtained after the correction of the blank (buffer-buffer + ligand). The solution was heated from 0 to $90{ }^{\circ} \mathrm{C}$ in acetate buffer $\mathrm{pH}=5.5,3$ atm and a rate of $2{ }^{\circ} \mathrm{C} / \mathrm{min}$. The ligand concentration was $120 \mu \mathrm{M}$.

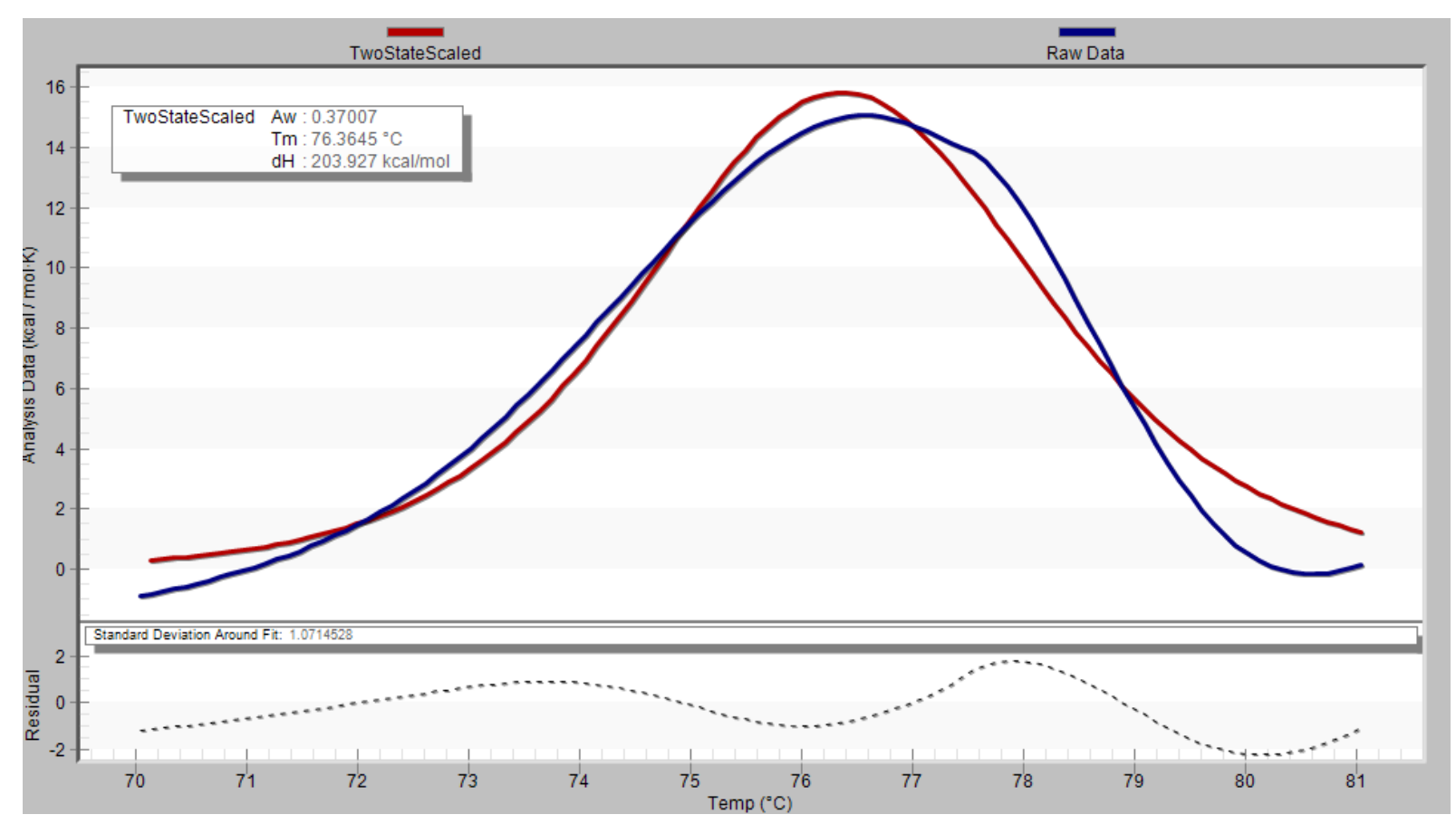

